\title{
TEORETIČNA IN VSEBINSKA ZASNOVA TRAJNOSTNO SONARAVNEGA NAPREDKA
}

\author{
Dušan Plut \\ Oddelek za geografijo Filozofske fakultete Univerze v Ljubljani, \\ Aškerčeva cesta 2, SI - 1000, Ljubljana, Slovenija \\ e-pošta: dusan.plut@ff.uni-lj.si \\ Izvirni znanstveni članek \\ COBISS 1.01
}

\section{Izvleček}

Udejanjanje načela trajnostnosti (trajnosti) na gospodarskem, družbenem in okoljskem polju pomeni trajno prilagajanje organizacije in (materialnega) delovanja družbe okolju. Trajnostno sonaravni razvoj oziroma (širše) napredek pomeni trajno (trajnostno) in hkratno izboljševanje materialne, socialne in okoljske kakovosti življenja. Geografija ima priložnost, da aktivno sodeluje pri udejanjanju sonaravnih vzorcev prostorske organizacije dejavnosti človeštva.

Ključne besede: okoljska trajnostnost, gospodarska trajnostnost, socialna (družbena) trajnostnost, trajnostno sonaravni napredek, geografija.

\section{THEORETICAL AND SUBSTANTIVE CONCEPT OF SUSTAINABLE CLOSE-TO-NATURE MANAGED PROGRESS}

\begin{abstract}
Implementation of the principles of sustainability in the economic, social and environmental field means that organisation and (material) operation of a society is permanently adapted to the environment. Sustainable close-to-nature managed development, or in a broader sense progress, means permanent (sustainable) and simultaneous improvement of material, social and environmental quality of life, thus a permanent raise of the welfare in its broader sense of all inhabitants within the capacities (limitations) of the environment. The opportunity of geography is to take an active part in the realisation of close-to-nature managed patterns of the spatial organisation of human activity.
\end{abstract}

Key words: Environmental sustainability, economic sustainability, social sustainability, sustainable close-to-nature managed progress, geography. 


\section{UVOD}

Bivanje, materialna dejavnost in preživljanje prostega časa človeške vrste je odvisno od naravnega okolja, delovanja planetarnega ekosistema. Okolje (globalni oziroma planetarni ekosistem) je vir energije in snovi, prostor za dejavnosti, opravlja ekološke storitve, hkrati pa sprejema emisije in odpadke, ki so posledica človekovih dejavnosti. Prebivalstvo in kapital sta ključni gonilni sili, ki povečujeta snovne in energijske (zlasti z rabo v fosilnih goriv) vnose $\mathrm{v}$ gospodarski del planetarneg okolja. $Z$ vse večjo predelavo surovin in pretvorbami energije se povečuje količina uporabnih materialnih dobrin, hkrati pa proizvajajo iznosi toplote, emisije, odpadne vode in odpadki, ki obremenjujejo sestavine (ponore) globalnega geografskega okolja (Graf 1) (Meadows in drugi, 1995). Obstojajo količinaske omejitve, do katerih lahko prebivalstvo in gospodarstvo uporablja materiale in energijo, kar velja tudi za zmogljivost predelave različnih odpadnih snovi, tekočin in plinov. Večplastna zmoglji-vost globalnega geografskega okolja (absorpcije, obnavljanja in regulacije) je tista kritična točka, ki jo ne sme prekoračiti svetovno gospodarstvo. Vsaka antropogena raba virov okolja je omejena s količino vira in ponori. Stanje planetarnega okolja, prevladujoči splošni trendi slabšanja kakovosti okolja in izčrpavanja naravnih virov v zadnjih desetletjih kažejo, da nenehnega povečevanja materialne blaginje na račun vse večjih antropogenih pritiskov na okolje ni mogoče nadaljevati v nedogled.

\section{Graf 1: Prebivalstvo in kapital v globalnem ekosistemu}

Figure 1: Population and capital in the global ecosystem

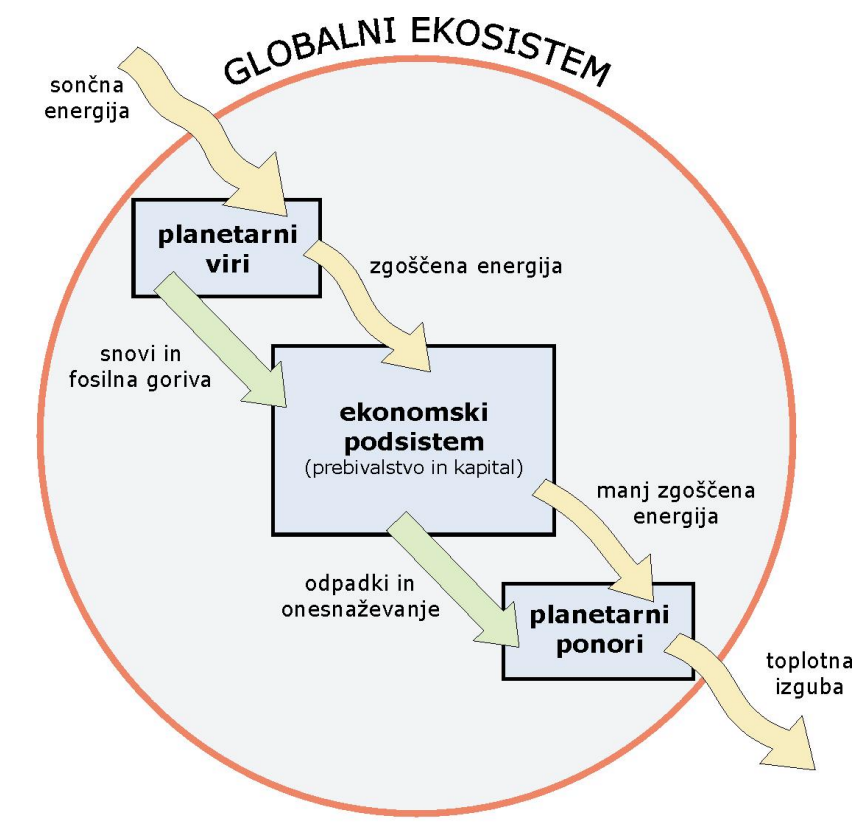

Oblikovanje: Andrej Herakovič 
Sveža vizija napredka človeštva o soodvisnosti varstva okolja, socialne (širše družbene) pravičnosti in gospodarskega razvoja je eden od najbolj verjetnih in možnih odgovor na civilizacijske, državne in regionalne izzive prihodnosti. Razlog za preusmeritev od cilja k procesu sprememb je spoznanje, da so svetovni problemi varstva okolja dejansko gospodarska in socialna vprašanja, ki niso rešljiva z blaženjem posledic, temveč s spreminjanjem motivov gospodarjenja (Dekleva 1992). Ekološka (okoljska) naravnanost razvoja je ključna novost nastajajoče paradigme, bolj naklonjene človeku in okolju (Mušič 1992). Nov okoljski imperativ postavlja politično prioriteto globalnega preživetja nad kratkoročnimi interesi nacionalne in lokalne gospodarske rasti. Narava ni problem, problem je človek in njegov odnos do narave (Anko 2000).

\section{KONCEPT TRAJNOSTNOSTI/SONARAVNOSTI V OPREDEL- JEVANJU RAZMERJA ČLOVEK-OKOLJE (NARAVA)}

Celostno pojmovana blaginja države, regije, družine ali posameznika je sestavljena iz gospodarske, socialne in okoljske blaginje. Slednja je bila prepuščena ekonomski stihiji, kar se kaže v prekomerni rabi naravnih virov in storitev okolja in s tem povezani degradaciji sestavin geografskega okolja. Okoljska zasnova drugačne paradigme in koncepta napredka človeške vrste je torej civilizacijski izziv, ki ga lahko primerjamo le z drugim globalnim izzivom-iskanja planetarnega sožitja v obdobju trka civilizacij, zlasti ti. zahodne (trenutno najbolj vplivne) in ostalih civilizacij (Huntington 1996). Globalnost ekonomskih, socialnih in okoljskih problemov zahteva globalen odgovor, stkan kot mreža ustreznih lokalnih odgovorov.

Danes je človeštvo na razvojni stopnji, da se morajo uveljaviti etične omejitve boja za obstanek tudi v odnosih do narave. Prehod v ti. ekološko družbo in ekološko kulturo ni mogoč brez temeljite spremembe naše celotne duhovnosti, etike, torej spremembe lestvice vrednot (Kirn 1994). Nova etika naj bi bila po mnenju Grmiča (1994) zasnovana kot etika odgovornosti za naravo, s spoštovanjem do narave, razumnostjo in zmernostjo, vzgojo za odgovorno skrbništvo do narave, vseh živih bitij.

Po mnenju Ferryja (1998) obstojajo tri različne smeri o vodilnem vprašanju odnosov med človekom in naravo:

1. prek narave je treba vedno in povsod ščititi človeka, okolje nima sebi lastne, notranje vrednosti, ni entiteta-antropocentrična smer;

2. ne smemo le iskati koristi za ljudi, vsa bitja, ki lahko občutijo ugodje in trpljenje, torej živali, je potrebno obravnavati kot pravne subjekte (ti. plitva ekologija oziroma »okoljska ekologija«)-reformistična antropocentrična smer kritike modernosti z ti. etiko okolja oziroma okoljevarstveno etiko;

3. zaščititi je potrebno naravo, celotne ekosisteme (vključno z neživimi sestavinami), biosfero, naravo, vesolje pred človekom-ti. globoka ekologija, »biocentrična oziroma ekocentrična«« ekologija poudarja, da je naravi, njenim sestavinam podeljena lastna, notranja vrednost; poudarja torej naravovarstveno etiko. 
Glede na izčrpavanje planetarnega ekosistema naj bi človeštvo prve polovice 21. stoletja eksistenco in celostni napredek namesto na antropocentrični etiki gradilo na nastajajoči okoljevarstveni etiki (okoljski etiki), katero označujejo naslednja temeljna načela (Plut 1998, 236):

- $\quad$ okoljska odgovornost (zdravo okolje, ohranjanje naravnih virov);

- medgeneracijska odgovornost;

- odgovornost ohranjanja vrst;

- $\quad$ socialna pravičnost;

- ravnovesje ciljev napredka človeštva (gospodarski, socialni, okoljski in regionalni).

Z vidika doseganja celostno pojmovanega napredka in trajnega ohranjanja bioloških pogojev življenja prihodnjih generacij je temeljno razmerje med gospodarskim razvojem (boljematerialnim napredkom) in varstvom okolja, ohranjanjem virov okolja. Po prvi konferenci OZN o človekovem okolju leta 1972 v Stockholmu so se začela bolj celovita, sistematična prizadevanja za povezovanje ciljev razvoja in varstva okolja, naravnih virov in narave. Tako je »okolju prilagojen gospodarski razvoj«, »ekorazvoj« označeval drugačno, širše razumevanje uspešnosti razvoja glede na uveljavljeno pojmovanje razvoja brez upoštevanja omejitev okolja. V strokovnih krogih se je pojem »sustainability« (SU) izoblikoval leta 1980 v podnaslovu poročila World Conservation Strategy o svetovni naravni dediščini Mednarodnega združenja za varstvo narave in naravnih virov (IUCN). »Sustainability« se je prvotno pojmovalo kot težnjo integracije varstva okolja in razvoja pod dežnikom koncepta »zaščite«, z naslednjimi smernicami za delovanje gospodarstva (Smith 1993, 2):

- ohranjanje ekosistema;

- $\quad$ zavarovanje genetske raznovrstnosti;

- omogočanje trajne rabe virov.

Z neposredno vključitvijo časovne razsežnosti v razpravo o okolju in razvoju, je navedena strategija odkrila njuni realni in upoštevanja vreden dejavnik združevanja ekonomije in »ekologije«. Čas in trajnost (trajnostnost) nudita skupnemu konceptu razvoja in okolja polje integracije, ki ustvarja prostor za številne pristope, vključno z učinkovitostjo, enakostjo, zaščito in upravljanjem $\mathrm{z}$ viri ter medgeneracijsko odgovornostjo (Khosla 1995, 8). S časom je ožje definirana Strategija zaščite sveta postala vse bolj osnova širše strategije, redefiniranega razvoja-»sustainable development«. Njegova popularizacija in široka uporaba, pojmovanje kot operativnega cilja za oblikovanje boljše prihodnosti pa se je uveljavilo po poročilu Svetovne komisije za okolje in razvoj iz leta 1987 (World Commission on Environment...1987). SU kot načelo integracije okolja v gospodarsko polje se pojmuje dvoplastno.

Načelo SU je bilo uvodoma uporabljeno za procese v okolju, torej za oznako ti. okoljske, ekosistemske, ekološke SU (environmental, ecosystemical, ecological sustainability). Označevalo je trajno ali trajnostno prilagajanje človekove materialne (gospodarske) dejavnosti zmogljivostim okolja, naravnih virov, narave. Pojem SU je torej v začetku označeval načelo, težnjo ohranjanja naravnega kapitala planeta $v$ procesu sprememb, ki jih prinaša nujnost gospodarskega razvoja (zadovoljevanje materialnih potreb). Podčrtuje torej nujnost delovanja človeštva znotraj zmogljivosti (omejitev) okolja. Pojem SU je poudarjal težnjo 
prilagajanja gospodarstva okolju, naravnim virom in naravi. Gospodarstvo, zasnovano na SU, ne more neskončno povečevati količinske rasti, le-ta ne more biti trajna na omejenem planetu, z omejenimi viri okolja. Rast prebivalstva in tradicionalne industrijske tehnologije povečujejo snovne in energetske tokove, kar hkrati povzroča izčrpavanje naravnih virov in onesnaževanje okolja (Graf 2) (McKinney in Schoch, 1998).

Graf 2: Okolje kot vir in ponor antropogenih snovno-energetskih tokov

Figure 2: Environment as a source and sinkhole of anthropogenic materially-energetic flows

Viri

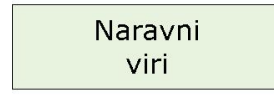

OKOLJE

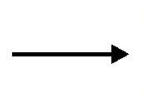

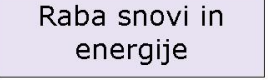

DRUŽBA
Ponori

Izčrpavanje virov

in onesnaževanje

OKOLJE

\section{- Prebivalstvo \\ - Tradicionalna industrijska tehnologija}

Zlasti Constanza (1991) pa je predlagal razširitev uporabe načela SU s polja gospodarski razvoj-omejitve okolja na socialno polje. Načelo SU se vse pogosteje pojmuje večplastno, stebri trajnostnosti so torej okolje (kot najširše polje), družba in gospodarstvo (EEA, 1999) (Graf 3). Ključna je sicer okoljska opredelitev načela SU, vendar vključuje tudi vidike revščine, neenakosti in pravičnosti (Viederman 1995, 41). Trodimenzionalnost pojmovanja SU je dodatni razlog, da napredka ne moremo meriti zgolj z ekonomskimi kazalci (BDP), saj je njihova rast lahko pogojena $\mathrm{z}$ povečanjem socialne neenakosti, poslabšanjem kakovosti okolja in izčrpavanjem naravnih virov. Pomembno vsebinsko dopolnilo SU na etičnem polju pa pomeni še vključitev medgeneracijske odgovornosti, torej namen ohranjanja zdravega okolja in naravnih virov za zadovoljevanje potreb prihodnjih generacij. Uvajanje prvin ekocentrične (biocentrične) etike pa prinaša vključevanje odgovornosti človeške vrste za ohranjanje biotske raznovrstnosti. Tako se novoveški antropocentrizem po mnenju Kirna $(2004,41)$ presega z nastajanjem ekocentrične zavesti, ko odnos do ostalega življenja in celotne narave tudi postaja predmet moralne presoje. Kljub temu, da ima človeška vrsta izjemne značilnosti (kulturo, tehnologijo, jezik), ostaja ena izmed mnogih vrst, ki je soodvisno vklučena v globalni ekosistem. Prst, rastine, živali, voda, zrak so bistvene predpostavke človekovega življenja. Tehnologija lahko začasno razširi meje zmogljivosti okolja, toda ekološki zakoni se ne dajo odpraviti.

Širša, večplastna zasnova pojma in uporaba načela SU predstavlja realno osnovo za holistično, trajnostno (trajno) zasnovano razvojno paradigmo družbe, ki prepoznava ključen pomen (trajne) integracije varstva okolja za doseganje humanega napredka in družbene enakosti sedanje in prihodnjih generacij. Prvotno, ožje, okoljsko pojmovanje načela SU, pa poudarja pomen ohranjanja naravnega kapitala in organizacije življenja v okviru omejitev okolja (regeneracijske in nevtralizacijske zmogljivosti) kot predpogoja za gospodarsko in 
socialno (družbeno) SU. Udejanjanje načela trajnostnosti na gospodarskem, družbenem in okoljskem polju pa pomeni trajno prilagajanje organizacije in (materialnega) delovanja družbe okolju, naravi in naravnim zakonitostim, torej sonaravnost delovanja kot temeljnega načina udejanjanja načela trajnostnosti (trajnosti) v praksi.

\section{Graf 3: Gospodarstvo, družba in okolje}

Figure 3: Economy, society and the environment

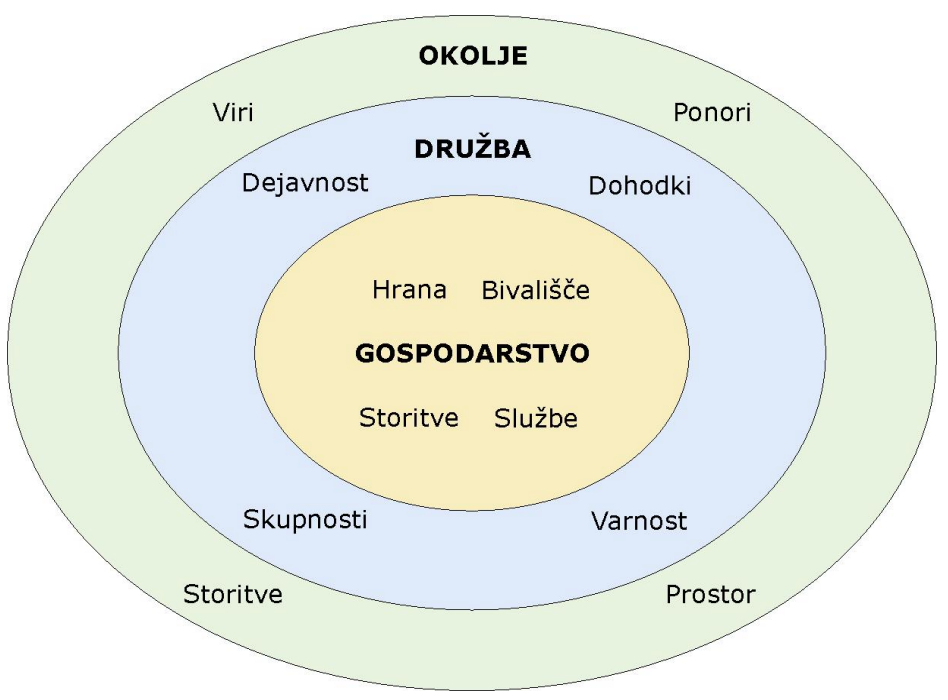

Koncept »sustainability« (SU), koncept trajnostnosti/sonaravnosti je torej potrebno vsebinsko dvoplastno pojmovati: kot enoplastno (okoljsko) ali večplastno načelo trajnosti oziroma trajnostnosti, katerega lahko udejanjamo (način organiziranja, delovanja) s sonaravnostjo oziroma sonaravno zasnovano dejavnostjo. Munro (1995) podčrtuje, da SU ni natančno določen cilj, temveč kriterij za prihodnje ravnanje in prakso. Viederman (1995) pa SU obravnava kot vizijo, ki nam omogoča, da se osredotočimo na niz vrednot, etična in moralna načela, ki usmerjajo naše delovanje. SU obravnava kot nadzor skupnosti nad kapitalom (naravnim, ustvarjenim, socialnim in kulturološkim), ki naj omogoči, da bodo sedanja in prihodnje generacije lahko dosegle visoko stopnjo ekonomske varnosti, demokracijo in hkrati ohranjale integriteto ekoloških sistemov, od katerih je odvisno življenje in produkcija. Osterc (1998) argumentirano poudarja, da v naravi vlada načelo trajnosti, katerega mora človek pri posegih $\mathrm{v}$ naravo upoštevati, posnemati.

Trajnostnost je umestno pojmovati kot načelo, kriterij presoje in sonaravnost kot praktično udejanjanje tega načela pri organizaciji in delovanju različnih materialnih dejavnosti (Plut 2002b). Z uporabo besede trajnostnost želimo torej podčrtati načelo ohranjanja naravnega kapitala in dolgoročno (trajno) zasnovanega delovanja gospodarstva in celotne družbe. $\mathrm{V}$ tem pomenu je primerna samostojna uporaba besede trajnostnost. Prav tako je uporaba pojma trajnostnost primerna, če želimo razen skrbi za okolje in dvig materialnega blagosta- 
nja poudariti širšo skrb za dvig kakovosti življenja, ki vključuje tudi družbeno polje, zlasti skrb za socialno varnost, zdravstveno vseh prebivalk in prebivalcev, odgovornost do prihodnjih generacij ter biosfere. Pojem trajnostnost je dejansko širši in večpomenski kot pojem sonaravnost, ki se veže na udejanjanje načel varstva okolja in narave, torej na okoljsko trajnostnost. Z besedo sonaravnost torej podčrtujemo način (usmeritev, smernica) za ohranjanje naravnega kapitala, naravi in okolju trajno (primerneje dolgoročno) prilagojeno delovanje (dejavnosti) družbe. V Slovenskem pravopisu $(2001,1458)$ so besede sonaraven, sonaravno gospodarjenje z gozdovi, /skladno z naravo/ sonaravnost; sonaravno pridelana hrana /naravna/. Beseda sonaravno (sonaravnost) v slovenskem jeziku prednostno označuje način delovanja, gospodarjenja, ki je skladen z naravo, pojem trajnostnost (trajne vrednote umetnine) pa označuje časovno razsežnost.

Sonaravnost kot uravnoteževanje delovanja z naravo in okoljem je torej proces, od nižje (šibke) k višji (trdi, močni) stopnji sonaravnosti skupnosti, gospodarstva. Sonaravni način materialnega življenja družbe, države, regije naj bi omogočila čim bolj dolgotrajno, torej trajnostno (trajno) delovanje in obstoj družbe. Sonaravnost delovanja družbe je torej način, smernica (smerokaz in hkrati pot) za dosego trajnostnosti kot medčasovne (medgeneracijske) kategorije, zgolj idealnega (zaradi neizogibne entropije vsake materialne dejavnosti) cilja (Plut, $2002 \mathrm{a}$, b). Današnje pojmovanje sonaravnosti ne pomeni zgolj živeti ob in od narave na trajnosten način. Dejansko daje podlago za preureditev človeške družbe po vzoru naravnih, samoregulirajočih in na dolgi rok stabilnih kompleksnih sistemov (Macarol 2001).

Planetarni ekosistem je prostorsko najobsežnejši in obsega tudi vse sisteme človeške vrste. Zato je prilagajanje (in posnemanje) na univerzalne planetarne ekosistemske omejitve, (prostor, naravni viri, samočistilne zmogljivosti), torej sonaravnost vseh človekovih materialnih dejavnosti, ključni predpogoj doseganja trajnostnega napredka gospodarstva. Regionalno (ali lokalno) pojmovana sonaravnost ali sonaravnost $\mathrm{v}$ okviru pokrajinskih ekosistemov pomeni prilagajanje dejavnosti človeka regionalnim omejitvam in trajno rabo virov regije na način, ki ne bo ogrozil delovanja regije, sosednjih območij in obremenjeval planetarni ekosistem. Vendar je potrebno upoštevati, da je na svetu vse več antropogenih ekosistemov. Poglavitna razlika med naravnimi in antropogenimi ekosistemi je v tem, da so naravni sposobni samoregulacije. Antropogene ekosisteme pa lahko po mnenju Macarola (2001) ohranjamo in trajno umetno vzdržujemo ob uporabi energije in snovi. To pomeni, da človek narave ne more v celoti posnemati, »naravno« delovati, zato je sonaravno delovanje primerna oznaka za naravni in kulturni pokrajini, naravnim in antropogenim ekosistemom čim bolj prilagojeno človekovo ravnanje.

Konec 20. stoletja je torej prišlo do povezovanja teorij razvoja in trajnostnosti (pojmovana z vidika načela »vzdržnosti« zaradi ohranjanja), nastala je nova paradigma razvoja (Bell in Morse, 2003). Razvoj se ne pojmuje zgolj ekonomsko, z vidika razvoja gospodarstva. Pomen je širok in večplasten, označuje enega ali vse načine dejavnosti ali procesov, ki povečujejo zmogljivost ljudi ali okolja za zadovoljevanje človekovih potreb ali izboljšanje kakovosti človekovega življenja (Munro 1995, 28). Produkt razvoja so ljudje, ki so zdravi, prehranjeni, oblečeni, imajo primerno bivališče, so usposobljeni za vključenost v produktivno delo, imajo socialno in zdravstveno varnost, enake možnosti za dvig kakovosti življenja, 
so sposobni za uživanje v preživljanju prostega časa ter usposobljeni za zaščito narave, okolja. Razvoj pa naj bi bil trajen, trajnosten, njegove koristi naj bi se ohranjale za prihodnje generacije.

Svetovna komisija za okolje in razvoj pri ZN (ti. Brundtlandina komisija) je v končnem poročilu Our Common Future (World Commission on Environment...1987, 43) najbolj citirano in uporabljeno, a hkrati vsebinsko ohlapno definicijo "sustainable development« (SD) opredelila kot: »obliko razvoja ali napredka, ki zadovoljuje potrebe sedanjosti brez ogrožanja zmogljivosti prihodnjim generacijam za zadovoljevanje njihovih potreb«. Bell in Morse $(2001,3)$ upravičeno opozarjata, da se pojem »sustainable development« pogosto uporablja kot sinonim za »sustainability«, kar povzroča še dodatne terminološke zaplete in nejasnosti. Munro (1995) predlaga, da je smiselno ločevati SU kot koncept, ključni kriterij presoje razvoja in SD kot dosegljiv cilj. Večji dobički, delovna mesta in dobrine so po njegovem mnenju brez učinka, če so doseženi na račun stroškov SU (Munro 1995, 35). $\mathrm{Z}$ vidika koncepta trajnostnosti/sonaravnosti je SD udejanjanje navedenega koncepta, zlasti na gospodarskem polju.

Ker je v ospredju razvojni vidik, SD označuje vse izboljšave razmer za človeka, torej tudi izboljšave izven gospodarskega polja (razvoja). V razliko od drugih makro teorij o razvoju se SD osredotoča na ljudi, na izboljšanje njihove kakovosti življenja, vključno s kakovostjo okolja in ohranjanjem virov za prihodnje generacije. SD je torej niz dejavnosti, ki naj bi trajno izboljšale razmere za človeštvo (Munro 1995). Vendar izboljšanje materialnih in socialnih razmer sedanje generacije ne sme biti doseženo na račun degradacije kakovosti okolja ( $\mathrm{v}$ širokem pomenu, torej $\mathrm{v}$ biofizikalnem in ekonomsko-socialnem pomenu) in virov, ki bi prihodnje generacije postavilo v neenakopraven položaj. Želja »izboljšanja« razmer, blagostanja za vse ljudi in upoštevanje potreb prihodnjih generacij (medgeneracijska enakost) sta temeljna cilja SD (Bell in Morse, 2003). Munro $(1995,29)$ izrecno podčrtuje, da je po njegovem mnenju za udejanjanje koncepta SU najbolj sprejemljiva bolj starejša, nekoliko ožja, a natančna definicija SD: »izboljšanje kakovosti življenja človeka znotraj nosilnih zmogljivosti oskrbnih ekosistemov«.

Zato SD ključno označuje (Loucks in Gladwell 1999):

1. razvoj, ki ne uničuje ključnih življenjskih oskrbnih sistemov planeta (zrak, voda, prst, biološki sistemi)-udejanjanje ekosistemske trajnostnosti/sonaravnosti;

2. razvoj, ki omogoča stalen tok dobrin in storitev, ki izhajajo iz naravnih virov planetaudejanjanje gospodarske trajnostnosti/sonaravnosti;

3. razvoj, ki zagotavlja pravično razporeditev koristi proizvodnje dobrin in storitev in ohranja življenjske oskrbne sisteme-udejanjanje socialne trajnostnosti/sonaravnosti.

Evropska agencija za okolje (EEA 1999, 49) in Bell ter Morse $(2003,4)$ opredeljujejo SD kot povezovanje, soodvisnost, sožitje sicer treh tradicionalno ločenih polj gospodarstva, okolja in družbe (sociale) (Graf 4). Lah $(1995,316)$ predlaga za SD prevod "trajnostni sonaravni razvoj ali okolje varovalni razvoj, obliko razvoja, ki zadovoljuje potrebe človeka, ne da bi pri tem ogrožala vire, od katerih je odvisen razvoj prihodnjih rodov". Kasneje (Lah 2002) pa trajnostno sonaravni razvoj opredeljuje kot »uravnotežen sonaravni razvoj, ki s tehnološkim napredkom in gospodarskim razvojem ohranja naravo in blaginjo prebivalstva ter 
je usklajen s strategijo trajnostnega razvoja, kar zagotavlja možnosti za ugodne življenjske razmere tudi zanamcem «

Slika 4: Povezanost gospodarskega, socialnega in okoljskega razvoja-stebri trajnostnostil sonaravnosti

Figure 4: Coherence of economic, social and environmental development-pillars of sustainability

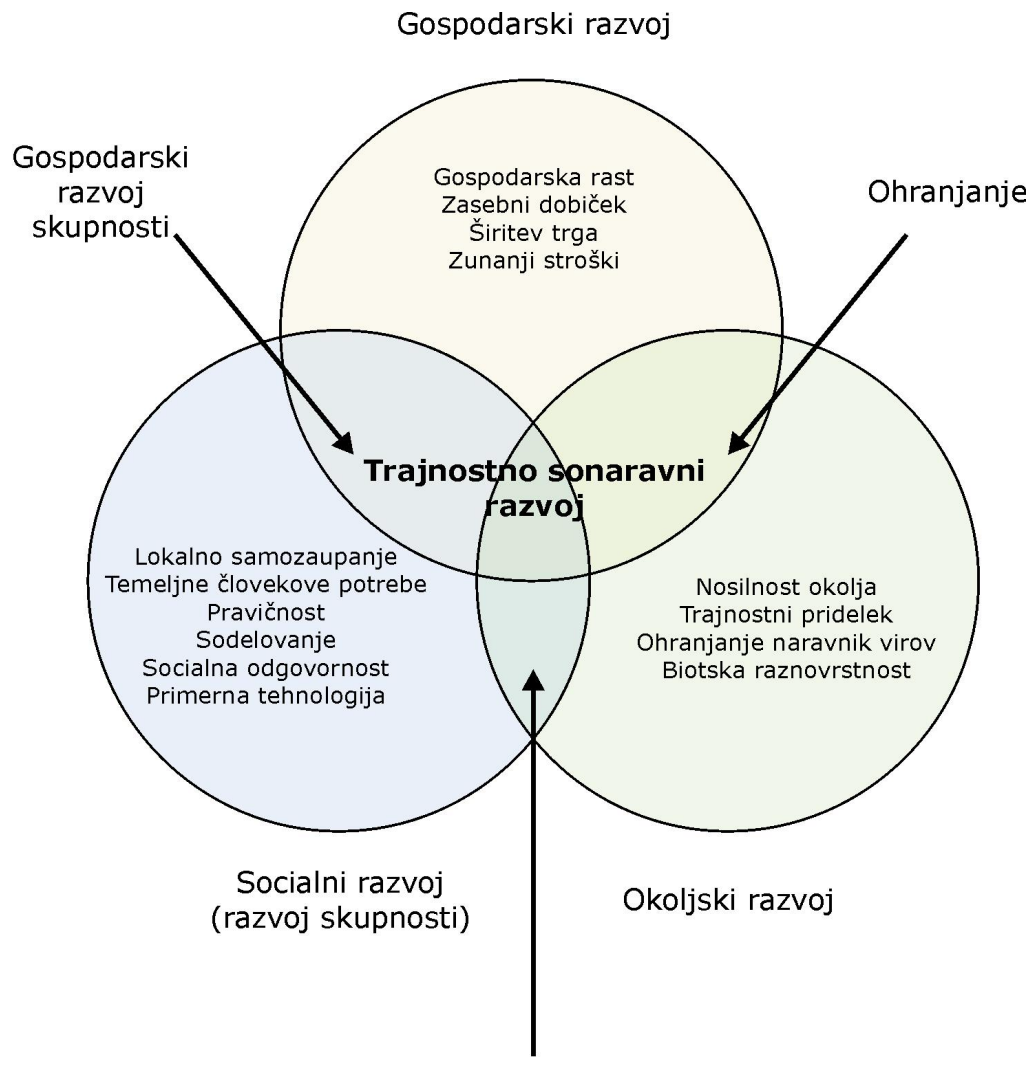

Globoka ekologija

Lah predlaga tudi uporabo pojma sonaraven (a. naturally harmonized) »ko ohranja naravo, je uravnotežen z okoljem in tudi dolgoročno razvojno usklajen« (npr. sonaravna tehnologija). Pojem trajnosten razlaga kot »sonaraven, naravo ohranjujoč in uravnotežen, usklajen ekonomsko in okoljsko za dolgoročno usmeritev razvoja« (Lah 2002, 139, 147). Čeprav Lah (2002) uporablja trajnosten kot sopomenko sonaraven, je opazna določena pomenska razlika. Pojem sonaraven definira nekoliko vsebinsko ožje, z okoljskega vidika, pojem trajnosten pa dvoplastno-okoljsko in razvojno oziroma ekonomsko. V leksikonu Geografija Kladnik $(2002,560)$ trajnostni razvoj opredeljuje kot sopomenko sonaravnemu razvoju. Špesova $(2000,25)$ uporablja pojem sonaravni (prostorski) razvoj, ki mora biti skladen s 
pokrajinsko občutljivostjo okolja. Seljak $(2000,15)$ sodi, da je primernejša uporaba pojma uravnoteženi razvoj, hkrati pa opozarja, da je navedeni pojem interdisciplinaren, in ga predstavniki posameznih strok različno razumejo.

Vsekakor je na mestu pripomba Pirnata in Anka $(2001,14)$, da trajnostni razvoj morda ni najbolj posrečen prevod angleške besede »sustainable«, katere pomen bi po njunem mnenju bolje opredelili z besedami kot npr. »zadžan, vzdrževan...«, saj ni v ospredju časovna dimenzija (trajno). Vendar sodita, da se je pojem trajnostni razvoj v okoljski zakonodaji pri nas že tako uveljavil, da je na mestu zgolj opozorilo na večplastni pomen izraza. Po njenem razmišljanju lahko besedo trajnostnost $\mathrm{v}$ okolju povezujemo $\mathrm{z}$ različnimi dejavnostmi kot npr. trajnostno gospodarstvo, trajnostna raba (v povezavi z rabo obnovljivih naravnih virov, organizmi in ekosistemi). V bistvu izraz označuje proces ali stanje, ki ga lahko vzdržujemo v nedogled, obenem pa opozarjata tudi na ločevanje med načeloma trajnostnosti in sonaravnosti (Pirnat in Anko, 2001, 14).

Osterc (1998) opredeljuje trajnostni razvoj z vidika družbe, gospodarstva in okolja. Posamezne dejavnosti, npr. kmetijstvo, ki sledijo načelu trajnosti in so torej zasnovane v največjem možnem posnemanju narave, pa označuje kot sonaravne dejavnosti, npr. sonaravno kmetijstvo (Osterc 1998, 68). Ferlin $(1997,81)$ uporablja pojem trajnostni razvoj gozdov in sonaravno gospodarjenje $\mathrm{z}$ gozdovi (close to nature forest managment), za oceno uspešnosti predlaga uporabo ekoloških, gozdnogospodarskih in socialno-ekonomskih kazalcev. Prosen (1993) uporablja pojem sonaravno urejanje podeželskega prostora, ki zagotavlja ravnotežje in raznolikost $\mathrm{v}$ prostoru ter nemoteno in uravnoteženo delovanje ekosistemov. Nacionalni program varstva okolja (2004) uporablja pojem trajnostni razvoj za oznako razvoja, ki omogoča preživetje tudi bodočim generacijam in poleg skrbi za preprečevanje in zmanjšanje onesnaževanja na viru poudarja tudi manjšo in bolj smotrno rabo naravnih virov ter ohranjanja biotska raznovrstnosti.

Za udejanjanje koncepta trajnostni/sonaravnosti je z vidika večplastno (gospodarsko, socialno in okoljsko) pojmovanega načela trajnostnosti, je umestno uporabljati pojem trajnostni (trajnostno) sonaravni razvoj oziroma napredek (TSR). Pomeni trajno (trajnostno) in hkratno izboljševanje materialne, socialne in okoljske kakovosti življenja, torej trajni dvig širše pojmovanega blagostanja vseh prebivalk in prebivalcev v okviru nosilnosti (omejitev) okolja. Označuje večplastno pojmovan človekov (humani) razvoj v okviru nosilnosti okolja in znotraj- ter med-generacijske pravičnosti. TSR je usmerjen v okoljsko, ekonomsko in socialno trajen napredek, izboljševanje blagostanja vseh prebivalcev v okviru zmogljivosti (omejitev) okolja v širšem pomenu besede. Razen varstva bivalnega okolja torej vključuje še varstvo naravnih virov in varstvo narave. Okoljsko (ekosistemsko) trajnostnost oziroma trajno (trajnostno) ohranjanje in delovanje okolja in narave se obravnava kot predpogoj za ekonomsko in socialno trajnostnost. Tako trajnostni sonaravni gospodarski razvoj oziroma napredek pomeni trajno izboljševanje materialne blaginje $\mathrm{v}$ okviru nosilnosti (omejitev) okolja. Trajnostni sonaravni socialni razvoj oziroma napredek pa se lahko definira kot trajno izboljševanje socialne varnosti vseh prebivalk in prebivalcev, socialnega blagostanja $\mathrm{v}$ okviru nosilnosti (omejitev) okolja.

Opustitev pridevnika »sonaravni« pri trajnostnem (gospodarskem, socialnem) razvoju pomeni tveganje, da se dvig gospodarskega in/ali socialnega blagostanja (dvig BDP, zma- 
njševanje revščine in brezposelnosti) dosega tudi na račun zmanjševanja okoljskega kapitala, torej zmanjševanja kakovosti bivalnega okolja, izčrpavanja naravnih virov, zmanjševanja zmogljivosti opravljanja ekosistemskih funkcij in zmanjševanja biotske raznovrstnosti. $\mathrm{V}$ primeru opustitve besede trajnostni pri sonaravnemu gospodarskemu in/ali socialnemu razvoju pa je prisotna nevarnost, da se podceni časovna razsežnost. Zgolj z vidika »sonaravne« sporočilne note koncepta trajnostni/sonaravnosti je vsebinsko samostojna raba pridevnikov vzdržni, uravnoteženi manj primerna, saj postavlja v ozadje trajno prilagajanje vseh materialnih dejavnosti naravnih zakonitostim, omejitvam okolja in prostora (sonaravnost).

Za udejanjanje (zgolj) tretje stranice trajnostnosti, torej za okoljsko trajnostnost se lahko uporablja oznaka trajnostni (trajnostno) sonaravni okoljski razvoj, vsebinsko je ustreznejši sonaravni okoljski razvoj (napredek). Udejanjanje okoljske trajnostnosti je dejansko predpogoj za udejanjanje ekonomske in/ali socialne trajnostnosti, saj sta gospodarski in socialni sistem (zgolj) sestavini širšega sistema-geosfere, planetarnega ekosistema. Sonaravni okoljski razvoj (napredek) označuje različne oblike materialnega delovanja, ki trajno ohranjajo in/ali izboljšujejo okolje, naravne vire, naravo. $Z$ drugega zornega kota bi (okoljski) sonaravni razvoj lahko označili kot trajni dvig »okoljskega« blagostanja, varstvo in ohranjanje okoljskega (naravnega) kapitala za prihodnje generacije in (drugo) biosfero.

\section{OKOLJSKA TRAJNOSTNOST/SONARAVNOST - KLJUČNA SMERNICA IN MERILO (TRAJNOSTNO) SONARAVNEGA RAZVOJA}

Okoljska trajnostnost/sonaravnost (OTS) (environmental sustainability) se je pojavila predvsem zaradi povečanega zanimanja o dolgoročnem zdravju planeta. Organiziranost dejavnosti v skladu $\mathrm{z}$ ekosfero dejansko določa trajanje človeške civilizacije (Kupchella in Hyland 1996). OTS opredeljujejo po mnenju Jacobsa $(1999,78,79)$ omejitve okolja (biofizikalne omejitve) za gospodarsko dejavnost, ki okvirno definirajo trajno ohranjanje zdravja ali integritete ekosistemov in zmogljivosti biosfere za opravljanje temeljnih okoljskih storitev, kot so čisti zrak in voda, regulacija podnebja, ohranjanje genetske raznovrstnosti, kroženja hranil itd. Geograf Haggett $(2001,797)$ pa OTS definira kot koncept rabe naravnih virov Zemlje za izboljšanje življenja ljudi brez zmanjševanja zmogljivosti planeta oskrbe življenja danes in v bodoče. Planetarni ekosistem je večplastno pomemben za človeško vrsto in svetovno gospodarstvo, saj (Graf 5) (European Environment Agency 1999, 39):

1. omogoča oskrbo z energijo in surovinami;

2. omogoča sprejemanje odpadkov in emisij;

3. opravlja ekološke (ekosistemske) storitve, ki so pomembne tudi za vse dejavnosti (npr. regulacije klime, proizvodnja kisika, zaščita pred erozijo prsti);

4. predstavlja prostor za lokacijo različnih dejavnosti.

Naravni kapital so vse tiste sestavine narave, ki jih uporabljamo oziroma so potencialno uporabne v ekonomskih in družbenih sistemih. Sestavljen je iz kritičnega in nekritičnega naravnega kapitala. Kritični naravni kapital (pomembni obnovljivi in neobnovljivi naravni 
viri, zmogljivost sprejemanja odpadkov itd.) je nenadomestljiv, lahko tudi pičel element narave (Clayton in Radclift 1996, 78). Ker naravni kapital ne obsega zgolj proizvodno in potrošniško pomembnih naravnih virov (surovinskih, energetskih), se uveljavlja uporaba širšega pojma okoljski kapital. Poleg tradicionalnih naravnih virov (les, mineralne surovine, voda) obsega tudi tisti del naravnih dobrin, ki jim je težko izraziti vrednost v denarju (filtracija zraka, vode, biološka raznovrsnost itd.) (Šolar, 2004). Najopaznejši in zato največkrat obravnavani okoljski problem ekonomskega razvoja je prekomerna raba okoljskega kapitala oziroma razvrednotenje okolja (Radej in drugi 2000, 13). Okoljsko oziroma ekološko trajnostnost po mnenju Munroja $(1995,29)$ določata a) oskrbni ekosistemi in b) nosilnost okolja za ljudi.

Slika 5: Ključne povezave okolja in gospodarstva

Figure 5: Key links between the environment and economy

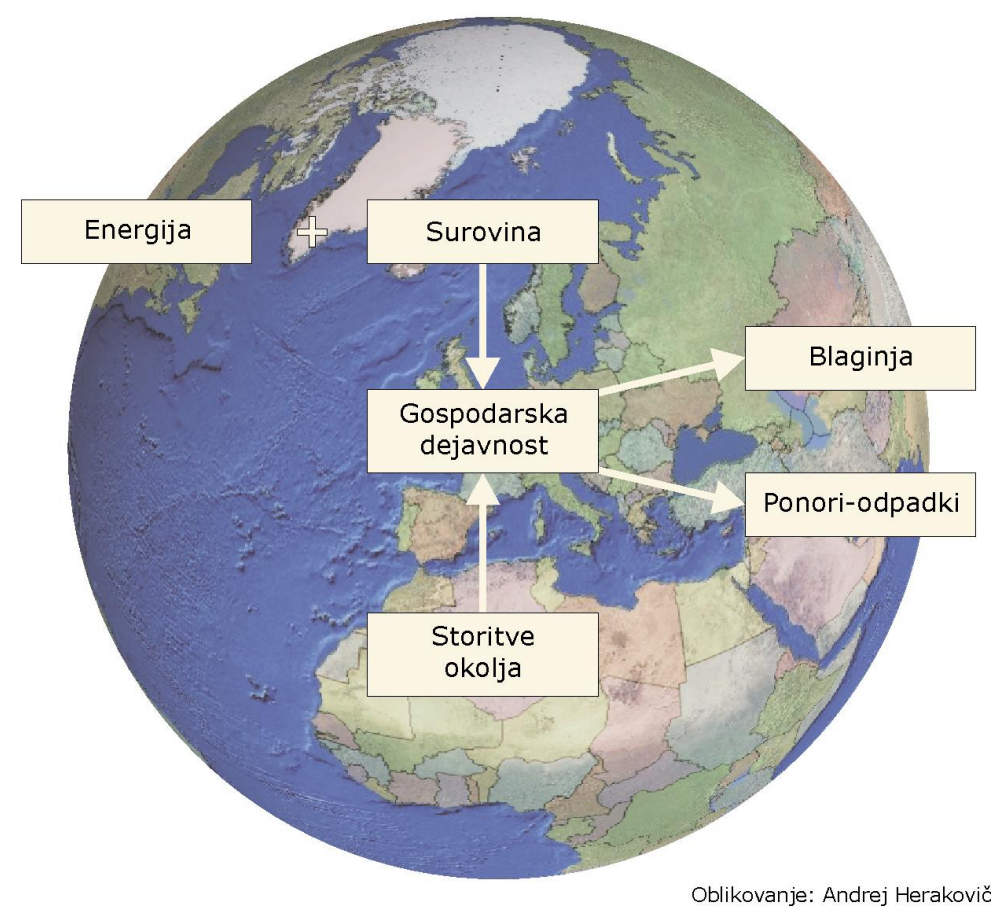

Oskrbni ekosistemi (supporting ecosystems) oziroma življenje podpirajoči ekosistemi označujejo stalne interakcije med organizmi, populacijami, združbami ter njihovim fizičnim in kemijskim okoljem (Barbier in drugi 1995, 45). Interakcije povzročajo številne ekološke vire in storitve, ki so ključne za ohranjanje človeške družbe in preživetje (Preglednica 1). Ekosistemi kot viri potreb za življenje, ki podpirajo oziroma oskrbujejo življenje, vključujejo zrak, vodo, energijo in surovine. Procesi, ki omogočajo življenje (obnavljanje prsti, globalni krogi vode, kemijskih elementov) lahko potekajo le znotraj ekosistemov, njihovo 
delovanje pa določajo številne omejitve v okolju, ki tako vplivajo na nosilnost okolja tudi za človeško vrsto (Munro 1995, 30). Načela in principe za organizacijo življenja civilizacij je potrebno zasnovati s pomočjo proučevanja (sestave, delovanja) naravnih ekosistemov, kot enot OTS (Nebel in Wright 1998, 23).

\section{Preglednica 1: Funkcije ekosistemov, ki podpirajo življenje}

Table 1: Functions of life-supporting ecosystems.

\begin{tabular}{|c|c|c|c|}
\hline Regulacijske funkcije & Produkcijske funkcije & Podporne funkcije & Informacijske funkcije \\
\hline $\begin{array}{l}\text { - zaščita pred nevar- } \\
\text { nimi kozmičnimi } \\
\text { vplivi } \\
\text { - regulacija podnebja } \\
\text { - zaščita porečja } \\
\text { - zaščita pred erozijo } \\
\text { prsti } \\
\text { - shranjevanje in } \\
\text { reciklaža odpadkov } \\
\text { - ohranjanje biotske } \\
\text { raznovrstnosti } \\
\text { - biološka kontrola } \\
\text { - omogočanje migra- } \\
\text { cij, varovanja in } \\
\text { prehrane habitatov }\end{array}$ & $\begin{array}{l}\text { - kisik } \\
\text { - pitna voda } \\
\text { - } \text { hranila } \\
\text { - voda za industrijo, } \\
\text { gospodinjstva itd. } \\
\text { - obleka in tkanine } \\
\text { - gradbeni, konstruk- } \\
\text { cijski in industrijski } \\
\text { materiali } \\
\text { - energija in goriva } \\
\text { - minerali } \\
\text { - medicinski viri } \\
\text { - biokemični viri } \\
\text { - genetski viri } \\
\text { - okrasni viri }\end{array}$ & $\begin{array}{l}\text { - bivanje } \\
\text { - kmetijstvo, gozdars- } \\
\text { tvo, ribolov, akva- } \\
\text { kultura } \\
\text { - industrija } \\
\text { - inženirski projekti } \\
\text { kot so jezovi in ceste } \\
\text { - rekreacija } \\
\text { - zaščita narave }\end{array}$ & $\begin{array}{l}\text { - } \text { estetske informacije } \\
\text { - duhovne in religioz- } \\
\text { ne informacije } \\
\text { - kulturološki in ume- } \\
\text { tniški navdihi } \\
\text { - izobraževalne in } \\
\text { znanstvene informa- } \\
\text { cije } \\
\text { - potencialne (nove) } \\
\text { informacije }\end{array}$ \\
\hline
\end{tabular}

Vir: Leveque in Mounolou 2003

Naš cilj je ohraniti procese, ne pa stanja ekosistemov, ki so odprti sistemi (Kryštufek 1999, 110). Varstvo okolja je učinkovito le v primeru, da v živi in neživi naravi ohranimo biološko ravnovesje, človekove dejavnosti je potrebno uskladiti z naravnim okoljem in razumno uporabljati naravne vire (Macarol 2001). Posegi človeka v lokalne in planetarni ekosistem zmanjšujejo obseg ekosistemskih funkcij in s tem sposobnost obnavljanja virov in nevtralizacije, asimilacije antropogenih obremenitev. Posegi v oskrbne ekosisteme se povečujejo zaradi povečevanja števila prebivalstva in porabe naravnih virov, njihova sposobnost oskrbe človeštva pa se zmanjšuje. $Z$ rabo zalog naravnih virov in prekomerno rabo obnovljivih naravnih virov se omogoča oskrba sedanje generacije, vendar na račun zmanjšanja naravnih virov prihodnjih generacij.

Zmanjševanje genetske, vrstne in ekosistemske raznovrstnosti, torej planetarnih bioloških virov, prinaša negativne posledice globalni biosferi in človekovemu blagostanju. Ohranjanje določene ravni biotske raznovrstnosti je za človeštvo vitalnega pomena, ne le zaradi omogočanja človekove proizvodnje in potrošnje, temveč zaradi omogočanja delovanja ekosistemov.

Vrsta (živalska, rastlinska) je bila v središču naravovarstvenih prizadevanj vse od njihovih začetkov, danes pa stopa vse bolj v ospredje upravljanje z ekosistemi (Kryštufek 1999, 127). Veliko učinkovitejši je torej pristop, s katerim ohranimo bistvene ekološke procese in glavne sestavine biodiverzitete. Sodobni pristop k upravljanju z ekosistemi se v nekaterih 
konceptualnih zadevah bistveno razlikuje od tradicionalne rabe naravnih dobrin. Ekosistem pojmuje kot neuravnotežen sistem, zato se namesto na tradicionalno »ekološko ravnotežje« raje sklicuje na dinamiko in elastičnost (Kryštufek 1999, 137). Barbier in drugi (1995) sodijo, da sicer ni realno pričakovanje o popolni zaščiti vseh vrst ali moratorij o rabi okolja, habitatov. Vendar je potrebno zagotoviti, da stopnja zmanjševanja biotske raznovrstnosti ne bo presegla ravni, ki je neobhodna za ohranjanje človekovega blagostanja in celo preživetja. Izkušnje zaščite vrst na regionalni ravni pa kažejo, da tako njihova neposredna ali posredna zaščita (zavarovana območja) ne zagotavljajo zaustavljanje erozije biološke raznovrstnosti, v kolikor izven območij zavarovanja ne prihaja do sonaravne rabe naravnih virov (Leveque in Mounolou 2003).

Nosilnost okolja (carrying capacity) označuje maksimalno velikost populacije določene vrste, katero lahko oskrbuje določeno območje brez zmanjševanja njegove zmogljivosti oskrbe iste vrste $\mathrm{v}$ prihodnosti (Barbier in drugi 1995, 229). Nosilnost okolja je funkcija značilnosti geografskega območja in organizmov. Populacija se lahko poveča, če se poveča nosilnost okolja (npr. količina hrane). Nosilna kapaciteta je torej največja populacija, ki je še uravnotežena $\mathrm{z}$ razpoložljivimi viri, predvsem s hrano in prostorom. Razpoložljivost virov se spreminja v času (npr. sezonska ali večletna nihanja), zato nosilna kapaciteta ni konstantna vrednost (Kryštufek 1999, 129).

Po Gilpinu $(1996,35)$ nosilnost okolja določajo sestavine okolja, kot so hrana, prostor za gnezdišča in drugi habitati. Predstavlja točko ravnovesja med potencialom reprodukcije in odporom okolja in je maksimum populacije, ki se lahko oskrbuje na trajnostnih osnovah. Jones in drugi $(1990,67)$ pa nosilnost okolja opredeljujejo kot optimalno velikost populacije, ki jih lahko določen habitat neskončno dolgo oskrbuje pod določenimi razmerami v okolju. Po mnenju nekaterih raziskovalcev pa naj bi nosilnost okolja imela trojni pomen (Therivel in Morris 2001, 471):

a) velikost populacije vrst (vključno s človeško), katero lahko določeno okolje oskrbuje;

b) zmogljivost habitata glede oskrbe ene ali več vrst;

c) zmogljivost (toleranca) ekosistema do določenih stresov, kot je raven onesnaževanja.

Vsaka degradacija okolja (onesnaževanje, pozidava itd.) zmanjšuje nosilnost okolja, zmogljivost opravljanja ekoloških storitev. Geograf Mitchell $(1979,37,177)$ opozarja na težavnost udejanjanja upoštevanja nosilnosti okolja, saj je potrebno razen biofizikalne nosilnosti okolja upoštevati tudi ti. sociološko, družbeno (behavioristično) nosilnost okolja (Graf 6). Biofizikalna oziroma ekološka nosilnost okolja je povezana s spremembami biofizikalnega okolja zaradi naravnih procesov in vplivov človeka. Družbena nosilnost okolja pa pomeni odnos prebivalstva do okolja, rabe naravnih virov, onesnaženosti okolja, npr. kako raba naravnega vira vpliva na zadovoljstvo npr. uporabnika rekreacije v primeru velike gneče in obiska. Sodobni, večplastni koncept nosilne zmogljivosti okolja za človeško vrsto postaja torej temeljen za razumevanje razmerja med ljudmi in naravnim okoljem. Nosilna zmogljivost se nanaša na populacijo, ki jo lahko oskrbuje določen ekosistem. Kritična meja planeta pa je nosilna zmogljivost planetarnega ekosistema. Koncept nosilnosti okolja je objektivna sonaravna smernica za organiziranost materialne dejavnosti določenega območja, pokraji- 
Slika 6: Koncept nosilnosti okolja

Figure 6: Concept of bearing capacity of the environment
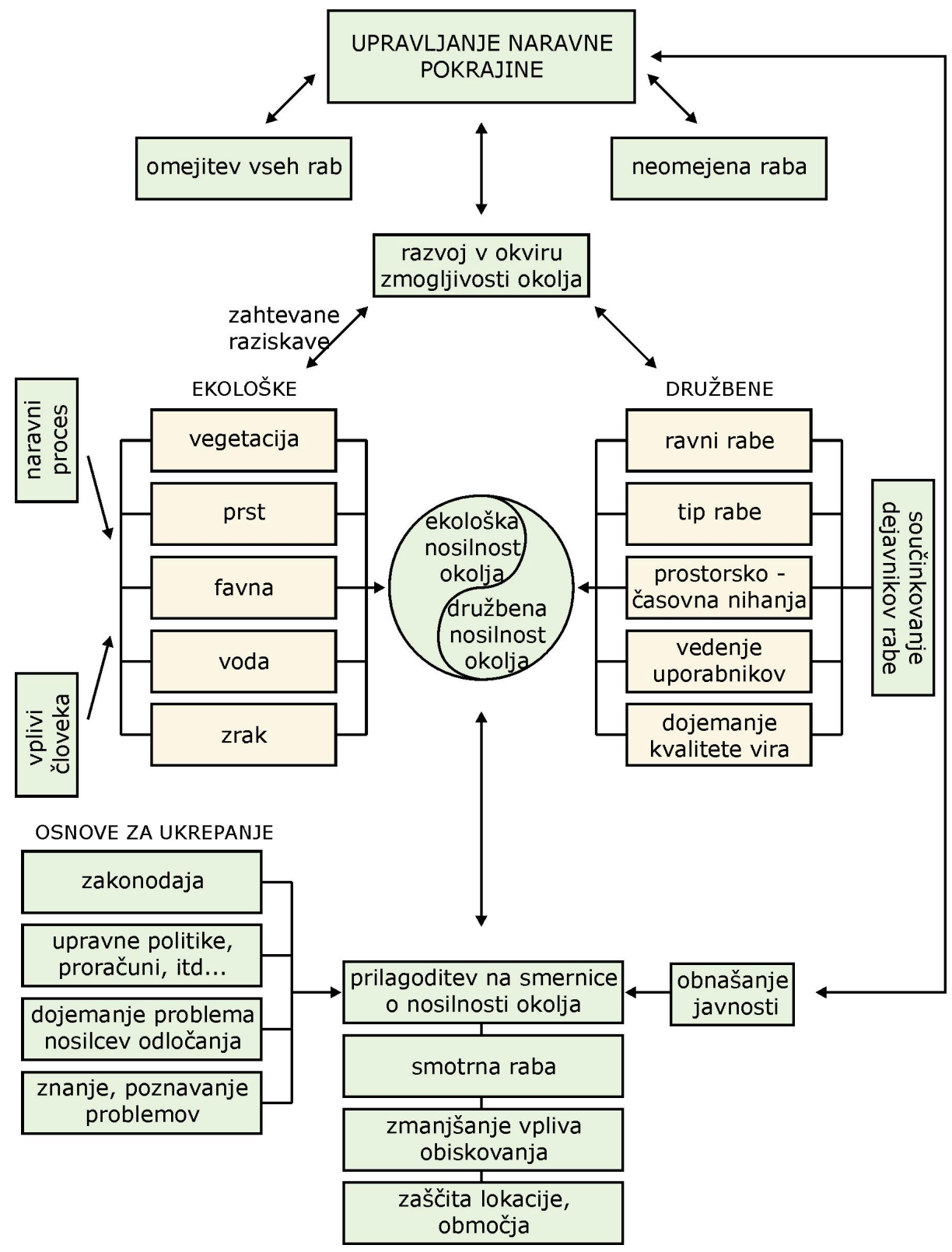

ne, regije. Za človeško populacijo je nosilnost okolja maksimalna stopnja porabe naravnih virov in proizvodnje odpadkov in emisij, ki je lahko globalno in regionalno dolgotrajna brez 
poslabševanja ekološke integritete in produktivnosti. Raven in stopnja izčrpavanja naravnih virov in obremenjevanja okolja ne sme biti večja in hitrejša od regeneracijskih ali absorpcijskih (asimilacijskih) sposobnosti sistemov okolja (Carley in Christie 1994, 43; European Environment Agency 1995, 13).

Temeljni dejavniki ocene širše pojmovane nosilne zmogljivosti okolja so (Clayton in Radclift 1996):

- $\quad$ raven populacije;

- zmogljivost obnavljanja obnovljivih virov;

- $\quad$ absorpcijske (nevtralizacijske) zmogljivosti okolja;

- rekreacijske zmogljivosti okolja (vključuje tudi percepcijo obiskovalcev)

Hkrati je potrebno upoštevati, da človek s poenostavljanjem (homogenizacijo) in vnosom umetnih sestavin zmanjšuje raznolikost in s tem nosilnost okolja, zmogljivost ter fleksibilnost ekosistemov ter povečuje občutljivost okolja (Prosen 1993; Redclift 1999; Plut 1998; Špes in drugi 1999).

Pojem nosilnosti okolja je bil najprej uporabljen v razmerju do ideje o trajnostnem oziroma optimalnem pridelku (Loucks in Gladwell 1999; Meadowcroft 1999). Teorija optimalnega pridelka pomeni obseg pridelka, ki ga smemo pobirati (količina žetve), ne da bi ogrozili kasnejši pridelek ali celo obstoj populacije, ki je predmet izkoriščanja (Tarman 1992, 165). Izhaja torej iz (naravnih) regeneracijskih zmogljivosti obnovljivih virov kot osnove za določanje količine rabe pridelka za človeško vrsto.

Drevesa, ribe in druge biološke vrste imajo sposobnost rasti in reprodukcije na stopnji, ki je višja od tiste, ki omogoča stabilizacijo populacije. Višja stopnja zmogljivosti označuje vse vrste in omogoča rast ali nadomeščanje populacije v obdobju naravnih nesreč. Zato lahko človeštvo vsako leto uporabi, odvzame določen delež dreves ali rib brez izčrpavanja gozda ali zmanjševanja ribje populacije pod določeno bazično število. Uporaba določenega deleža donosa je mogoča neskončno dolgo, če je ta delež v okviru regeneracijske zmogljivosti populacije. Netrajnostna uporaba se pojavi takrat, ko poseg ali ribolov preseže zmogljivost reprodukcije in rasti. Trajnostni pridelek začne upadati, v kolikor je pri bioloških virih presežena kritična točka, postane populacija premajhna, da bi se lahko obnovila (Graf 7) (Rees 1992; Nebel in Wright 1998). Ekosistemi lahko določeno obdobje delujejo nad ravnijo trajnostnega donosa (npr. s pomočjo uporabe umetnih gnojil), vendar preseganje povzroča resne okoljske probleme (Jones in drugi 1990). Podobna zasnova o optimalni, trajnostni rabi velja tudi pri črpanju podtalnice, v kolikor črpanje ne presega zmogljivost obnavljanja vodnih zalog.

Osnovna zahteva OTS v sedanjem civilizacijskem trenutku je ohranjanje zaloge naravnega kapitala (materiali, energetski viri) (Constanza 1991) oziroma širše, virov okolja, ki vključuje še ekosistemske storitve in biotsko raznovrstnost (ekološki viri in storitve) (Barbier in drugi, 1995). Glede na navedena načela OTS bi bilo ustrezneje namesto naravnega kapitala uporabljati pojem kapital okolja oziroma okoljski kapital. Le-tega namreč tvorijo naravni viri (v ožjem pomenu) in storitve okolja, kot so kroženje snovi in drugi naravni procesi, ki vračajo razvrednoteno okolje v prvotno ali bolj kakovostno stanje (Radej in drugi 2000, 11). 
Graf 7: Krivulja trajnostnega pridelka

Figure 7: Sustainable yield curve

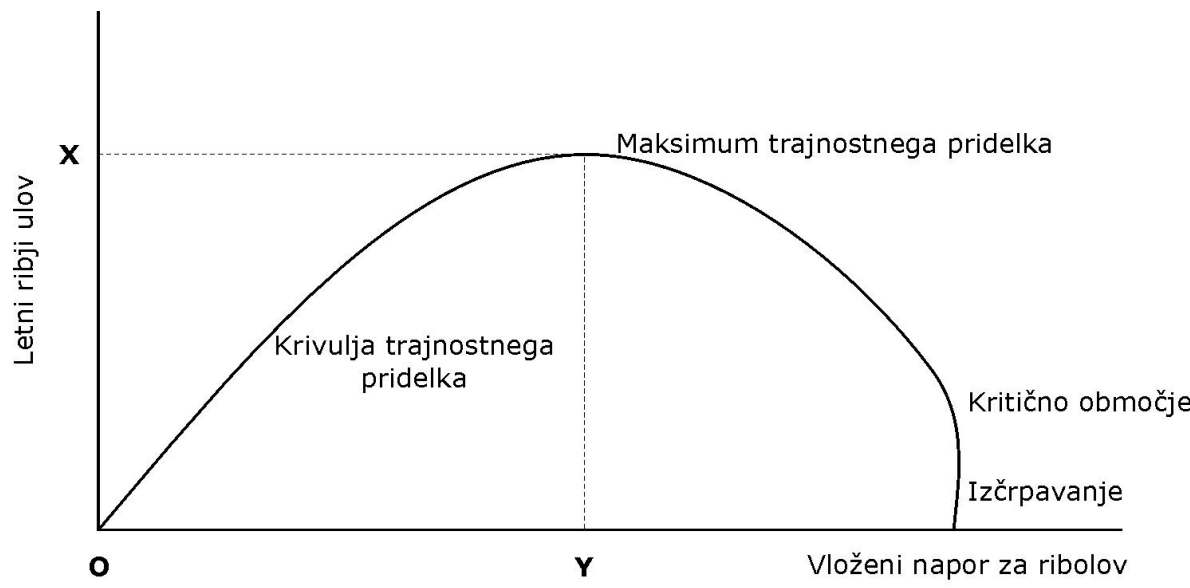

OX - Maksimum letnega pridelka $v$ soglasju s trajnostno zmogljivostjo vira

OY - Letni vloženi napor, potreben za mamksimiranje trajnostnega pridelka

Oblikovanje: Andrej Herakovič

Izčrpavanje zalog neobnovljivih naravnih virov in prekomerna raba obnovljivih naravnih virov (nad stopnjo obnavljanja) sta ključna kazalca netrajnostne, nesonaravne porabe naravnega kapitala planeta, povečevanja entropije in vira obremenjevanja okolja. OTS upravljanje z omejenim naravnim kapitalom (širše-z viri okolja) naj bi po Dalyju (1991a) opredeljevalo upoštevanje treh temeljnih pravil:

1. stopnja rabe obnovljivih naravnih virov ne sme preseči njihove stopnje obnavljanja (regeneracije);

2. stopnja rabe neobnovljivih naravnih virov ne sme preseči stopnje zamenjave $\mathrm{z}$ obnovljivimi;

3. stopnja različnih emisij (in odpadkov) ne sme preseči absorpcijske zmogljivosti okolja.

$\mathrm{Z}$ vidika radikalnejših, torej ne le okoljevarstvenih vidikov (varstvo bivalnega okolja in naravnih virov), temveč tudi naravovarstvenih vidikov (upoštevanje elementov ekocentrizma) bi lahko dodali še naslednje načelo:

4. antropogenizacija narave ne sme pospeševati hitrosti naravnega izumiranja živalskih in rastlinskih vrst oziroma zmanjševati biotsko raznovrstnost.

Trajnostno sonaravni razvoj lahko zasnujemo zgolj na bazičnih principih življenjskih sistemov, kot modelov za človeštvo, ki so (Nebel in Wright 1998, 73, 74, 104):

1. ekosistemi odstranjujejo odpadke in se oskrbujejo s hranili (krogi ogljika, kisika, dušika itd.); 
2. ekosistemi uporabljajo kot vir energije stalni priliv sončne energije;

3. število populacije potrošnikov v ekosistemu se ohranja na način, ki preprečuje prekomerno rabo biomase;

4. ohranja se biotska raznovrstnost (biološka diverziteta), najbolj stabilni so ekosistemi z največjo stopnjo bioraznovrstnosti.

Primerjava človeških sistemov z bazičnimi principi OTS kaže na veliko neskladje (Nebel in Wright 1998):

1. ekosistemi odstranjujejo odpadke in se oskrbujejo s hranili s pomočjo reciklaže vseh elementov - človeški sistemi (poselitveni, proizvodni itd.) so zasnovani na enosmernem toku elementov (snovi), onesnaževanje okolja in izčrpavanje naravnih virov sta ključni posledici enosmernega proizvodno-potrošniškega toka elementov;

2. ekosistemi uporabljajo kot vir energije sončno energijo, ki ne onesnažuje in se ne izčrpava - velika odvisnost človeških sistemov od neobnovljivih fosilnih goriv; ključni problem je povezava porabe goriv in omejenih zmogljivosti biosfere za absorpcijo ti. soproduktov zgorevanja goriv (onesnaževanje zraka, segrevanje ozračja);

3. število populacije potrošnikov se ohranja na način, ki preprečuje prekomerno rabo biomase - narašča tako število svetovnega prebivalstva kot potrošnja na prebivalca; nujna bi bila stabilizacija obeh procesov.

4. ohranja se raven biotske raznovrstnosti - zaradi posegov človeka se spreminjajo habitati v smeri monokultur in prisotno je antropogeno izumiranje vrst.

Ključno za razumevanje in udejanjanje OTS je torej ključno prepoznavanje pomena podprtosti materialne dejavnosti s a) stalno reciklažo vseh elementov in b) rabo sončne energije kot primarnega energetskega vira. Tako je za doseganje visoke stopnje trajne rabe obnovljivih vodnih virov potrebna zlasti zaščita in podpora zmogljivosti obnavljanja (količine in ustrezne kakovosti) okolja (Loucks in Gladwell 1999).

Med koncepti globalne ocene omejitev oziroma zmogljivosti okolja za materialne dejavnosti sodobne civilizacije so v ospredju analiza ti. ekoloških odtisov in okoljskega prostora. Oceno zmogljivostim geosfere oziroma planetarnega ekosistema prilagojeno stopnjo obremenjevanja okolja in porabe naravnih virov prinaša koncept okoljskega prostora (environmental space) (Hille 1997). Po mnenju Bella in Morsa $(2003,13)$ je koncept ekoloških odtisov, stopinj (ekological footprint) kot okvirno merilo rabe naravnih virov, antropogenih vnosov v določenem okolju (preračunano $\mathrm{v}$ ha/prebivalca) zasnovan na izhodiščih opredeljevanja nosilnosti okolja.

OTS smernice kažejo, da je za (trajnostno) sonaravni razvoj ključno: prehod k obnovljivim energetskim virom, visoka stopnja reciklaže, ohranjanje razmerja med gozdnimi, kmetijskimi in pozidanimi površinami ter bistveno zmanjšanje porabe nekaterih naravnih virov in obremenjevanje okolja na prebivalca (za okoli štirikrat na prebivalca) $v$ gospodarsko razvitih državah. Celostnost in soodvisnost območij in sestavin planetarnega ekosistema pa opozarja na nujnost dviga materialne blaginje prebivalcev držav v razvoju v okviru nosilnosti okolja. Zaradi velike pokrajinske občutljivosti ozemlja držav v razvoju (tropski in subtropski ekosistemi) so samočistilne zmogljivosti v državah razvoja praviloma manjše od ozemlja gospodarsko razvitejših držav zmernega pasu. 
Zmogljivost okolja glede oskrbovanja $\mathrm{z}$ naravnimi viri in absorpcije emisij in odpadkov predstavlja absolutno omejitev človekovih dejavnosti. Princip okoljske zmogljivosti zahteva, da so regije, mesta oblikovana in vodena na način zadovoljevanja temeljnih okoljskih, družbenih in gospodarskih storitev znotraj omejitev okolja. Daly (1991b) sodi, da je potrebno zaradi zmanjševanja količine in kakovosti naravnega kapitala investicije preusmerjati iz investicij v ustvarjeni kapital k zaščiti in izboljševanju naravnega kapitala. Tako naj bi bila prednostna naloga zaščita štirih kategorij naravnega kapitala, ki nimajo tržne vrednosti (biosferska infrastruktura): a) zaščita ozonske plasti, b) zaščita spodnje atmosfere (z zmanjšanjem toplogrednih plinov), c) zaščita mednarodnih vodnih virov in d) zaščita biotske raznovrstnosti. Prepoznavanje omejenih zmogljivosti naravnega okolja za sprejemanje emisij in odpadkov, omejenosti naravnih procesov obnavljanja ter materialno manj intenzivni vzorec prednostno določa smernice za »eko-rekonstrukcijo« proizvodnje in potrošnje (Hudson 2000).

Ocena še sprejemljivega obsega rabe naravnega kapitala in antropogenih pritiskov na oskrbne ekosisteme, ocena nosilnosti okolja za človeštvo na osnovi objektivnih kazalcev, je praktično nemogoča. Tako kot je nemogoče objektivno odgovoriti na vprašanji »koliko je dovolj« in kolikšen je »človeka vreden materialni standard «. Vendar je po mnenju Munroja $(1995,31)$ najboljši pristop, da človeštvo ostane znotraj omejitev nosilnosti okolja, prizadevanje za ohranjanjem zdravja in produktivnosti vseh sestavin ekosistema. Predlaga torej uporabo načela previdnosti, zaščito ključnih oskrbnih ekosistemov, ohranjanje biotske raznovrstnosti, rabo obnovljivih virov znotraj njihove zmogljivosti obnavljanja, minimizacijo rabe neobnovljivih naravnih virov. Pri določanju trajnostnosti vsake razvojne dejavnosti je potrebno razen gospodarskih in družbenih (vključuje tudi etično podstat) dejavnikov upoštevati tudi okoljske (ožje ekološke) dejavnike.

OTS torej označuje več ključnih kazalcev: delovanje oskrbnih ekosistemov, ti. trajnostni (optimalni) pridelek, nosilnost okolja za človeško vrsto, ohranjenost biotske raznovrstnosti, stopnja rabe neobnovljivih in obnovljivih naravnih virov, pokrajinska raba, pokrajinska občutljivost in ranljivost območja, ekosistema, pokrajine. Zmanjševanje antropogenih vnosov, njihovo približevanje zmogljivosti okolja, naravnih virov je kazalec zahtevnega načina udejanjanja okoljske trajnostnosti. Tudi sonaraven, a manj zahteven (šibka sonaravnost) in za gospodarstvo bolj sprejemljiv način udejanjanja okoljske trajnostnosti je povečevanje snovne, energetske in emisijske učinkovitosti na enoto proizvoda, storitve, torej povečevanje ti. ekoučinkovitosti v celotnem življenjskem krogu kot prvega koraka v smeri OTS.

Izhajamo iz teze nekdanjega ekonomista Svetovne banke Dalyja (1991b), da je svetovno gospodarstvo iz obdobja omejitev razpoložljivega ustvarjenega kapitala prešlo v obdobje, ko je ključna omejitev naravni kapital (naravni viri, širše viri okolja). Če se bo svetovno gospodarstvo kot podsistem planetarnega okolja širilo na enak način kot do sedaj, bo v določenem trenutku kot rakasto tkivo uničilo naravne sisteme, ki ga omogočajo. Ekonomski kazalci (rast BDP) sveta kot celote so v zadnjih desetletjih pozitivni, okoljski (izčrpavanje naravnih virov, kakovost okolja) pa vse bolj negativni. Sedanji gospodarski sistem je zasvojen s količinsko rastjo, zanika posledice v okolju in ne upošteva omejitev oziroma nosilnost naravnih sistemov (Brown in Mitchell 1998). Večina gospodarske rasti je še vedno nevzdržno pogojena s povečanjem porabe naravnih virov in storitev okolja (Radej 2001a). 


\section{GOSPODARSKA TRAJNOSTNOST/SONARAVNOST IN NARAVNI KAPITAL}

\section{Naravni kapital, entropija gospodarstva in gospodarska rast}

Dolgoročno uspešno gospodarstvo je po neoklasičnem ekonomskem pristopu odvisno od razmerja med koristmi in stroški, koristi morajo preseči stroške oziroma vsaj doseči medsebojno ravnovesje (Munro 1995; Jacobs 1999). Gospodarska uspešnost je pogojena z razpoložljivostjo in stroški vnosov, stroški proizvodnje in povpraševanjem po proizvodih, storitvah. Gospodarska trajnostnost/sonaravnost (economical sustainability) (GTS) pa izhaja iz središčne vloge naravnega okolja v gospodarstvu. GRS temeljno opredeljuje, da se v gospodarskih procesih naravni viri uporabljajo na načine, ki ne presegajo zmogljivost obnavljanja naravnih virov in ne poškodujejo okolja (Munro 1995, 33).

Po GTS naj bi visoko ustvarjeno materialno blaginjo dosegli s čim manjšim razvrednotenjem okolja. Ekonomska rast je torej omejena s hitrostjo obnavljanja naravnih virov in samočiščenja okolja. Okoljski ekonomisti izhajajo iz obravnave okolja (naravni vir, nosilec ekosistemskih storitev in prejemnik emisij) kot naravnega (okoljskega) kapitala za gospodarski razvoj. Večplastno pojmovani nosilnosti okolja se mora regionalno in globalno trajnostno sonaravno gospodarstvo prilagoditi, zmogljivosti okolja kot oskrbovanje $\mathrm{z}$ viri in absorpcija odpadkov in emisij so absolutne omejitve gospodarski dejavnosti človeka (Pearce 1993, 1994; European Environment Agency 1995).

Gospodarstvo je (le) del geosfere, neupoštevanje zakonitosti širšega sistema s povratnimi loki pripelje do pogubnih posledic v celotnem sistemu. Ekonomskemu procesu in tržnem mehanizmom je torej potrebno postaviti meje, ki jih narekuje ohranjanje planeta. Postavljene naj bi bile zgornje meje izkoriščanja naravnih virov in zgornje meje onesnaževanja okolja. Te meje naj bi v prihodnosti določale vsaj oblike, če ne tudi obseg ekonomske dejavnosti (Georgescu Roegen 1986 in 1991; Kovač 1986; Barbier in drugi 1995; Seljak 2000).

Relativnost težnje po trajnostnosti podčrtuje prisotna ireverzibilnost materialnih dejavnosti človeka (pozidava, raba neobnovljivih naravnih virov, izumiranje vrst zaradi človeka itd.), ki jo lahko izrazimo s pomočjo entropijskega zakona oziroma kot zmanjševanje naravnega kapitala prihodnjim generacijam. Zato je koncept entropije in njegova uporaba za zasledovanje nepovratnosti materialnih procesov (npr. izčrpavanja fosilnih zalog talne vode) zelo uporaben (Loucks in Gladwell 1999). Zmanjšanje entropije v gospodarskem subsistemu namreč zahteva naraščanje entropije ostalega dela sistema, torej okolja. V kolikor pa »ostanek» sistema vključuje Sonce oziroma smotrno rabo sončne energije, potem je mogoče doseči zmanjšanje entropije $v$ antropogenih sistemih brez naraščanje entropije $v$ pokrajinskih ekosistemih. Materialna dejavnost, načrtovanje gospodarskega razvoja, posegov v prostor mora zagotavljati ohranjanje in delovanje življenjsko oskrbnih sistemov in izogibanje nepovratnosti degradacije okolja in virov.

Sedanja svetovna ekonomija je visoko entropijska, saj se samo majhen del vnešenega energetsko-materialnega toka dejansko pretvori v koristni proizvod, storitev. Kljub dejstvu, da torej reciklaža ne more biti $100 \%$, to še ne pomeni nezmožnost obstoja stabilne ekono- 
mije, saj jo omogoča stalni priliv sončne energije (Seljak 2000). Potrebna pa je radikalna sprememba tehnologije industrijskega metabolizma, vključno s spremembo energetske osnove civilizacije. Optimalno raven proizvodnje in s tem povezane potrošnje, nosilno sposobnost okolja, je težko definirati. Ob prepoznavanju dejstva, da ekonomski proces črpa nizko entropijo iz naravnih virov in jo pretvarja $v$ visoko, je potrebno ta tok zmanjšati na najmanjšo možno mero. Torej naj bi bile postavljene zgornje meje izkoriščanja naravnih virov in zgornje meje onesnaževanja virov okolja, kar okvirno omogočata koncepta ti. okoljskega prostora in ekoloških stopinj (Hille 1997; Plut 2002c).

Ocene kažejo, da je način, oblike in obseg svetovnega gospodarstva zlasti zaradi velike porabe naravnih virov in obremenjevanja okolja na prebivalca gospodarsko razvitih držav planetarno in medgeneracijsko nesprejemljiv, saj že sedaj presega nosilnost planetarnega ekosistema. Ekonomskemu procesu in tržnemu mehanizmu je potrebno postaviti meje, ki jih narekuje ohranjanje planeta, njegovih temeljnih ekosistemskih storitev. Nosilnost planeta naj bi v prihodnje uvodoma določala zlasti obliko, če ne tudi obseg globalne in lokalnih gospodarskih ter drugih materialnih dejavnosti.

Gospodarstvo je odprt sistem, ki uporablja velike količine materialnih in energetskih virov, ki jih odvzame iz okolja. Uporaba energije in materialov v ekonomskem procesu je podobna tisti pri ekosistemih: samo majhen del energetskega in materialnega toka, ki se vnaša v ekonomski proces se dejansko pretvori v izdelek (Plut 1991; Barbier in drugi 1995; Seljak 2000). Upravičena je torej oznaka industrijski metabolizem, ki ni v ravnovesju z okoljem in s snovno-energetskimi pretvorbami povečuje entropijo okolja. Mednarodno menjavo naravnih virov oziroma surovin in energetskih virov lahko posebej obravnavamo tudi kot »uvažanje« trajnostnosti, a hkrati kot pospeševanje izčrpavanja naravnih virov v državah izvoznicah ter s tem na globalni ravni (Seljak 2000). Sprememba lokacije, prostorsko premeščanje virov onesnaževanja okolja bistva industrijskega metabolizma ne rešuje (Hudson 2000).

Od začetkov moderne ekonomije je dolgoročna ekonomska rast osrednja tema teoretikov rasti, kot sta Smith in Marx. Za zgodovino zadnjih 200 let je značilna neprestana gospodarska rast, povečalo se je tako število prebivalcev, zlasti pa količina in kakovost proizvodnje. To je obdobje, za katero je značilna vera v možnost nezadržne rasti na vseh področjih (Seljak 2000, 6). Prevladovala je mehanicistična koncepcija ekonomskega procesa kot krožnega toka (povezava produkcije in potrošnje) znotraj popolnoma zaprtega sistema, ki naj ne bi vplival na kvalitativne spremembe v okolju.

Ekonomska rast je empirično opredeljena kot rast bruto domačega proizvoda in pomeni predvsem količinske spremembe. V nasprotju z ekonomsko rastjo pa naj ekonomski razvoj označujejo tudi kakovostne spremembe. Po definiciji Svetovne banke (The World Bank 1992, 34) pomeni gospodarski razvoj izboljšanje blagostanja ljudi, zato so povečevanje življenjskega standarda, izboljšanje izobrazbe, zdravja in enakost dostopa njegovi širše opredeljeni cilji. Vendar tako strokovnjaki Svetovne banke in Svetovne komisije za okolje in razvoj (ti. komisija Brundtlandove) sodijo, da je gospodarska rast ključna za razvoj. Tudi Senjur (1993) sodi, da je za uresničitev gospodarskega razvoja potrebno, da se gospodarstvo količinsko povečuje, da raste. 
Po mnenju okoljskega ekonomista Pearca $(1994,4,5)$ je nerealistično pričakovanje, da je mogoče socialne probleme sveta rešiti brez ekonomske rasti. Le-to pa je potrebno doseči z manjšo porabo surovin in energije, prehodom $\mathrm{k}$ rabi obnovljivih energijskih virov in učinkoviti reciklaži materialov s pomočjo tehnološkega napredka. Doseganje višje stopnje sonaravnosti dejavnosti $\mathrm{v}$ določen obdobju pomeni povečanje stroškov dejavnosti. Zaščita pred onesnaževanjem okolja oziroma njegovih sestavin je dolgoročno cenejše kot odpravljanje posledic onesnaževanja in označuje višjo raven udejanjanja koncepta trajnostnosti/ sonaravnosti (Loucks in Gladwell 1999).

V okviru prevladujoče ekonomske teorije in prakse je po mnenju Seljaka $(2000,26)$ ekonomski razvoj dejansko enačen s pojmom ekonomske rasti. Vendar tudi zagovorniki gospodarske rasti prepoznavajo, da gospodarska rast v določenih primerih ogroža okolje, prihodnje generacije in nekaterim skupinam sedanje generacije lahko prinaša gospodarske koristi, drugim pa poslabšanje okolja. Tako Svetovna banka uporablja nekoliko nejasno definiran pojem ti. učinkovite gospodarske rasti, ki naj ne bi bila okolju nasprotujoča (The World Bank 1992). Ključ naraščanja gospodarske dolgoročnosti (trajnosti) po njihovem mnenju ni proizvajati manj, temveč proizvajati drugače, okolju bolj prilagojeno, snovnoenergijsko učinkovitejše.

Ekonomski proces s krožnim tokom dohodkov in izdatkov (podjetja-trgi proizvodnih tvorcev-gospodinjstva-trgi proizvodov-podjetja) torej ne prepoznava entropijske (linearne) narave proizvodnje in potrošnje (Georgescu Roegen 1986; Plut 1991; Seljak, 2000). Industrijska družba ima izrazito linearno strukturo (namesto snovno krožne) (Graf 8) (Stahel 1996): surovine-polproizvodi-proizvodi-potrošnja (uporaba dobrine)-odpadek Ob napačni predpostavki, da je ekonomski proces zaprt (snovno-energetsko) krožni tok, nikoli ne bi bile presežene zmogljivosti okolja. Proste okoljske dobrine pa so postale redke, krožni ekonomski tok je postal zavajajoč, saj ne vključuje izkoriščanja naravnih virov (vnos) in obremenjevanje okolja (iznos kot odlaganja različnih emisij, odpadkov) kot entropične posledice (degradacije) transformacije energije in surovin (naravnih virov) $v$ proizvodno-potrošniškem procesu. Ob prepoznavanju enosmernosti entropičnega loka postane opredelitev optimalne ravni izkoriščanja še bolj pomembna kot optimalna alokacija (Seljak 2000, 30).

OTS poudarja, da obstojajo omejitve rabi zalog in prilivov snovi in energije $\mathrm{v}$ proizvodnji in potrošnji. To pa ne pomeni, da obstojajo omejitve za vse tokove snovi in energije, prav tako so velike tehnološke možnosti tudi ekonomsko smotrnejše rabe energije in materialov v proizvodnji in potrošnji. Podobno velja za gospodarski razvoj, z vidika GTS je v ospredju okoljska (ne)sprejemljivost gospodarske dejavnosti. Načelo trajnostnosti zahteva dolgoročne strukturalne spremembe, ne le v povpraševanju po dobrinah in storitvah (tržni vidik), temveč tudi v uporabi okoljskega kapitala, tehnologijah, infrastrukturi, življenjskem slogu.

Zavračanje napačne predpostavke o krožnem toku, prepoznavanje entropične narave enosmernega ekonomskega toka in izčrpavanje oziroma razvrednotenje omejenega naravnega kapitala zaradi narave gospodarskega razvoja so ključne oznake ti. okoljske ekonomije (environmental economy) in širše, entropijsko-ekonomske razvojne paradigme. 
Graf 8: Linearno in potencialno krožna zasnova gospodarstva

Figure 8: Linear and potentially circular conception of economy

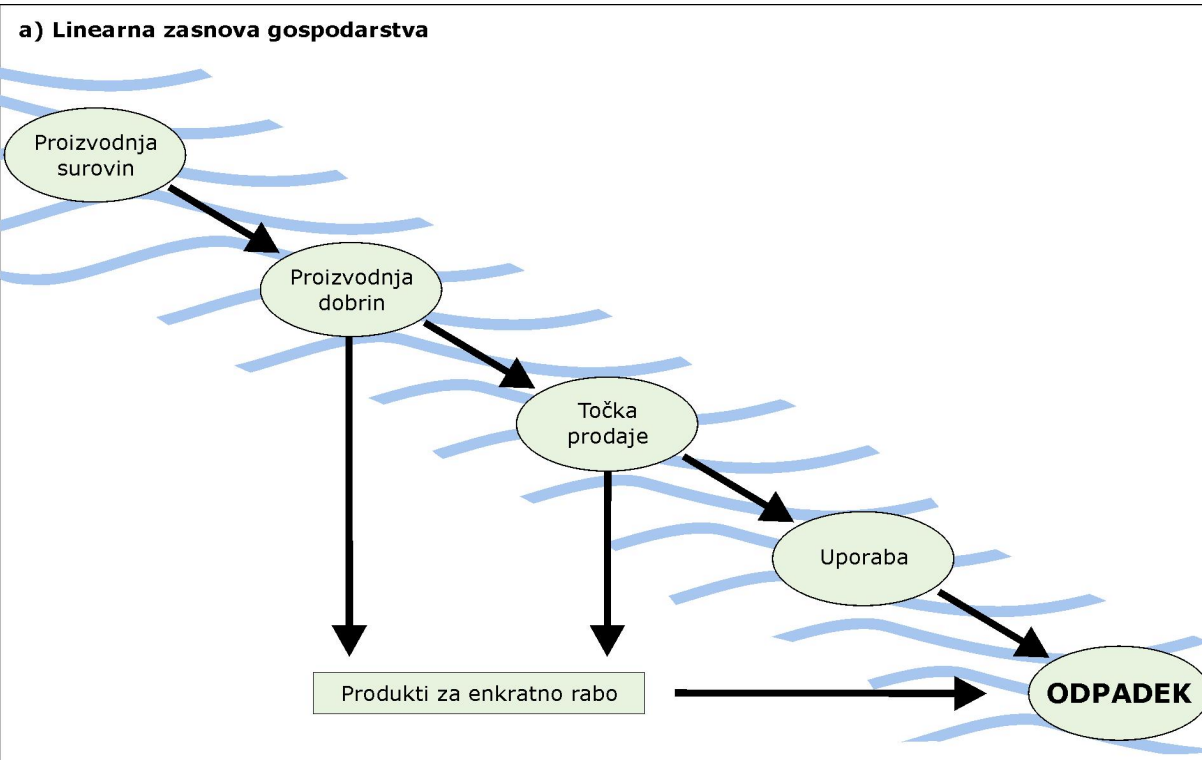

b) Potencialni krožni tok gospodarstva

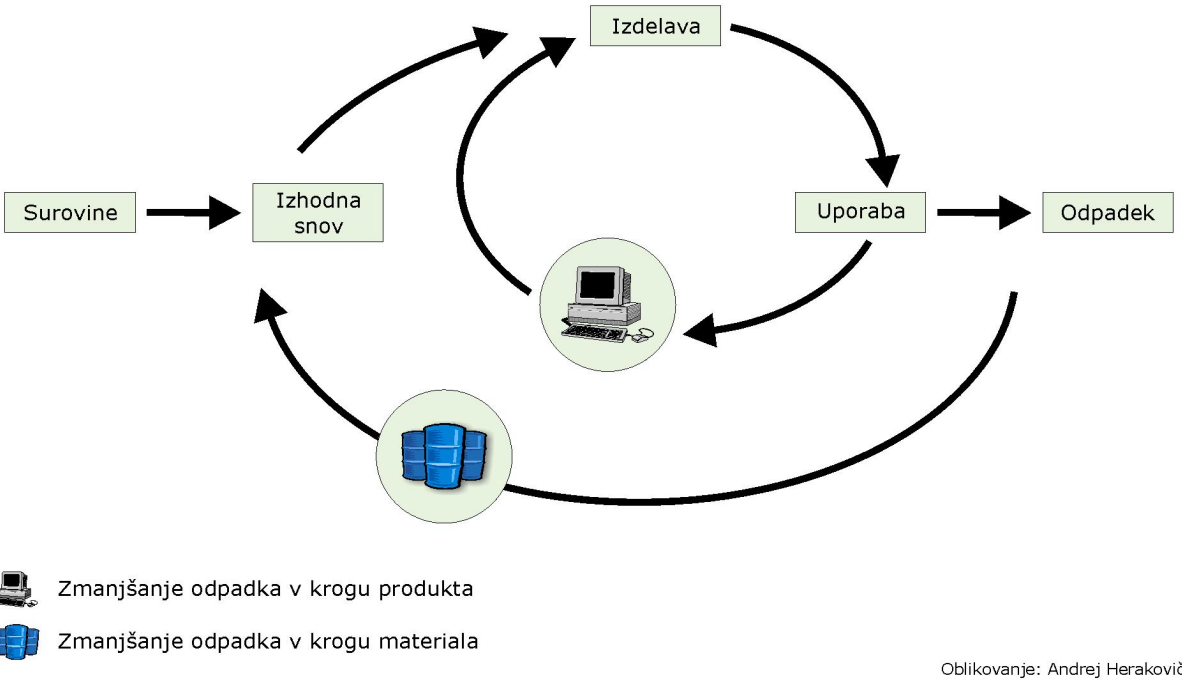

\section{Tržno gospodarstvo in okoljska trajnostnost}

Med ekologisti in ekonomisti so zelo različna mnenja o možnostih in poteh doseganja gospodarske in okoljske trajnostnosti s pomočjo tržnih mehanizmov. Po mnenju Radeja (1992, 
2001a) za nastanek problemov okolja ni kriv tržni mehanizem kot takšen, temveč način njegove uporabe, saj si trg ne more svojih meja (omejitev) postavljati sam. Zasluge trga za nepovratno razvrednotenje okolja so se verjetno doslej precenjevale, saj tudi izginjajoči socialistični, netržni gospodarski sistem označuje degradacija okolja, pa tudi globalna gospodarska nekonkurenčnost. $\mathrm{Z}$ zakonskimi in ekonomskimi instrumenti po mnenju Claytona in Radcliffa (1996) lahko spodbujamo proizvajalce in potrošnike za zmanjševanje obremenjevanja okolja, reciklažo, rabo obnovljivih energijskih virov. Skupni stroški odpravljanja posledic onesnaževanja okolja in rabe primarnih surovin ter fosilne energije morajo biti $\mathrm{v}$ primernem obdobju višji kot stroški uvajanja okoljevarstveno primernejših tehnologij in rabe obnovljivih virov energije.

$\mathrm{V}$ definicijah ekonomistov in ekologov obstojajo ključni razliki tako v pojmovanju možnosti gospodarske rasti kot $\mathrm{v}$ pojmovanju pomena naravnega kapitala $\mathrm{v}$ skupnem kapitalu za prihodnje generacije. Razlike so posledica različnega gledanja in predpostavk o prihodnjem pomenu sestavin družbenega kapitala (naravni, fizični in ustvarjeni) z vidika medgeneracijske odgovornosti oziroma pravičnosti. Ekologi poudarjajo, da se je potrebno z vidika prihodnjih generacij osredotočiti na zaščito naravnih virov (Loucks in Gladwell 1999, 29). Ekonomisti pa izhajajo iz predpostavke, da je potrebno izhajati iz celotne sestave družbenega kapitala, ki obsega naravne vire (okolje), znanje, pridobljen kapital itd. V poskusih približevanja ekološkemu gledanju vključujejo nekateri ekonomisti v ekonomske izračune naravni kapital, vendar vseh funkcij ekosistemov ni mogoče denarno ovrednotiti. Ekonomska uspešnost je zasnovana na dobičku, le-ta pa na rasti. Količinsko večanje gospodarstva (ne pa rast kakovosti) kot podsistema planetarnega ekosistema je nezdružljivo z univerzalnimi omejitvami (prostor, naravni viri, samočistilne zmogljivosti okolja). Gre za nasprotje med ekonomskim konceptom maksimalnosti dobička in ekološkim konceptom optimalnosti. Nekateri ekonomisti še vedno zagovarjajo predvsem tezo, da ima globalno okolje visoko nosilno sposobnost in tokovi onesnaževanja naj še ne bi dosegli kritične ravni.

Po mnenju Jacobsa $(1999,86)$ neoklasični, tržni model gospodarskih analiz problemov okolja ni uporaben:

1. zaradi biofizikalne osnove trajnostnosti-zahteva po ohranjanju biofizikalnih zalog in tokov; ne obstoja nujnost povezave med ohranjanjem naravnih virov in tržno zasnovano prioriteto posameznega potrošnika;

2. kolektivni značaj trajnostnosti - večina problemov okolja, s katerimi se ukvarja koncept sonaravnosti (npr. globalni problemi segrevanja ozračja, zaščita pred širjenjem puščav, ohranjanje biotske raznovrstnosti) ni problem individualnega blagostanja, kjer naj bi posameznik (potrošnik) plačal za ohranjanje skupnih dobrin; trg je v svojem bistvo individualistična inštitucija, kjer se posameznik odloča na osnovi lastnega interesa;

3. zahteva po medgeneracijsko pravični razdelitvi uporabe naravnih virov - etična, moralna zahteva je lahko le politična izbira, ne more pa biti tržna izbira; trg se ne ukvarja z razporeditvijo virov, temveč $\mathrm{z}$ njihovo tržno (maksimalno) uporabo v določenem trenutku.

Raziskave opozarjajo na težavnost ocene eksternih stroškov in medgeneracijsko zasnovano razmerje med koristmi in stroški. S pomočjo neoliberalnega ekonomskega modela je praktično nemogoče upoštevati stroške globalnega segrevanja, tanjšanja ozonske plasti ali izgu- 
bo biotske raznovrstnosti (Redclift 1999, 74). Vendar težave npr. zagotavljanja sonaravne rabe skupnih dobrin oziroma virov okolja ne smejo biti opravičilo za njihovo ignoriranje.

Imperativ kratkoročnega zmanjševanja stroškov ne sme biti izgovor za slabšanje dolgoročnih gospodarskih možnosti in neupoštevanja okoljske trajnostnosti. V kolikor ohranjanje okolja povzroča dodatne, eksterne (zunanje) stroške, morajo biti vključeni v ceno proizvoda, storitve. Izključevanje okoljskih stroškov je pripeljalo k nizki ceni tako naravnih virov kot ponorov za shranjevanje različnih oblik emisij, odpadkov, odpadne vode, ključna posledica pa je visok snovno-energetski tok in onesnaževanje okolja (Graf 9). Z višjimi cenami naravnih virov in obdavčenjem odlaganja različnih odpadkov, torej z internalizacijo stroškov okolja se naj bi zmanjšali snovno-energetski tokovi, spremenilo obnašanje potrošnikov in zmanjšalo onesnaževanje okolja (Kovač 1986; McKinney in Schoch, 1998; Jacobs 1999). Zaščito okolja naj bi omogočili zlasti ekonomski instrumenti kot so davki, dajatve, prenosna dovoljenja za onesnaževanje, torej finančne spodbude proizvajalcem in potrošnikom, da zmanjšajo okolju škodljivo ravnanje. V okviru (tradicionalne) ekonomske analize pa je najpomembnejši koncept ekonomske učinkovitosti in ne optimalnosti, ki se opredeljuje s stališča blaginje družbe (Seljak 2000). Imperativ zmanjševanja stroškov ne sme biti opravičilo za neupoštevanje okoljske trajnostnosti. Dodatne okoljske stroške je torej potrebno vključiti v ceno proizvoda, storitev, ki jo tradicionalno sestavljajo stroški kapitala, dela, surovin in energije. Finančne omejitve so ključne za skromno število sonaravnih praks (Loucks in Gladwell 1999). Potreba po ti. zeleni davčni reformi ne označuje zgolj predloge radikalnih okoljskih aktivistov. Davki na onesnaževanje okolja naj bi postopoma zamenjevali obdavčenje dela in kapitala (Redclift 1999, 76).

Tipično je, da vrednotenje stroškov in koristi obsega raven le sedanje generacije (Pearce 1993, 6). Ena izmed pomanjkljivosti okoljskih stroškov in koristi je, da ne odraža teh razmerij za bodoče generacije, torej ne upošteva medgeneracijskega učinka stroškov in koristi. V trgu ali v ekonomskem načrtu ni niti povpraševanja niti ponudbe prihodnjih generacij, vsak nov izdelek pomeni manj plugov za neke oddaljene generacije (Georgescu Roegen 1986). Gospodarstvo naj bi oznako trajnostnosti zaslužilo le v primeru, da ohranja oziroma povečuje gospodarske priložnosti v nedefinirano prihodnost. Zgolj učinkovitost gospodarstva $z$ vidika rabe naravnih virov torej še ne zagotavlja doseganje trajnostnosti in gospodarskih priložnosti za prihodnje generacije. Ključno je ohranjanje baze naravnih virov v vsakodnevnem delovanju gospodarstva (Barbier in drugi 1995, 39).

Podobna oblika neenakopravnosti je tudi znotraj generacije: pripravljenost plačevanja je odraz dohodkov tistih, ki naj bi bili pripravljeni plačevati. Ekonomski glas revnih šteje na trgu manj kot ekonomski glas (volja) bogatih, gre torej za problem intrageneracijskega učinka.

Okoljski stroški dejavnosti morajo biti organska sestavina ekonomskih izračunov, obdavčiti je potrebno snovno-energijske tokove in onesnaževanje okolja. Davčna politika bi morala znižati davke na delo in varčevanje ter zvišati davke na škodljive dejavnosti za okolje kot so emisije ogljikovega dioksida in žveplovega dioksida, odpadkov, uporaba neobdelanih surovin in uporaba pesticidov. Obdavčitev bi podražila okolju in virom škodljive dejavnosti in posredno spodbujala uporabo sonaravnih načinov, »okoljsko trajnostno gospodarstvo« (environmentally sustainable economy) za zadovoljevanje človekovih potreb (Brown in Mitchell 1998). 
Graf 9: Učinki upoštevanja okoljskih stroškov na antropogene snovno-energetske pretoke Figure 9: Effects of taking account of environmental costs on anthropogenic materially-energetic flows

a) Okoljski stroški niso vključeni

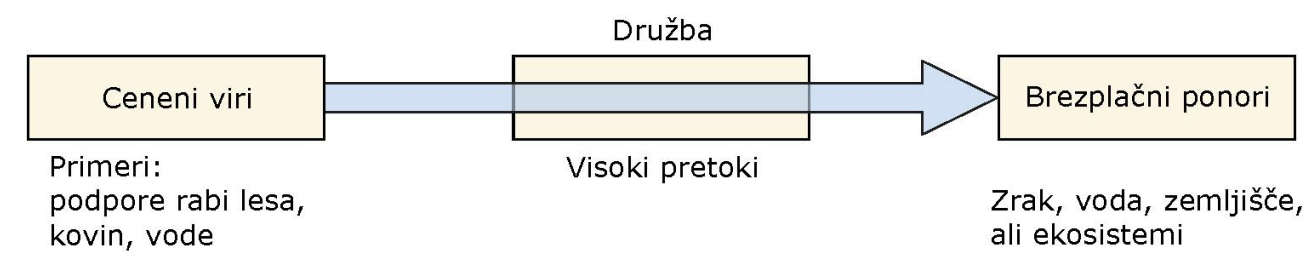

b) Okoljski stroški so vključeni

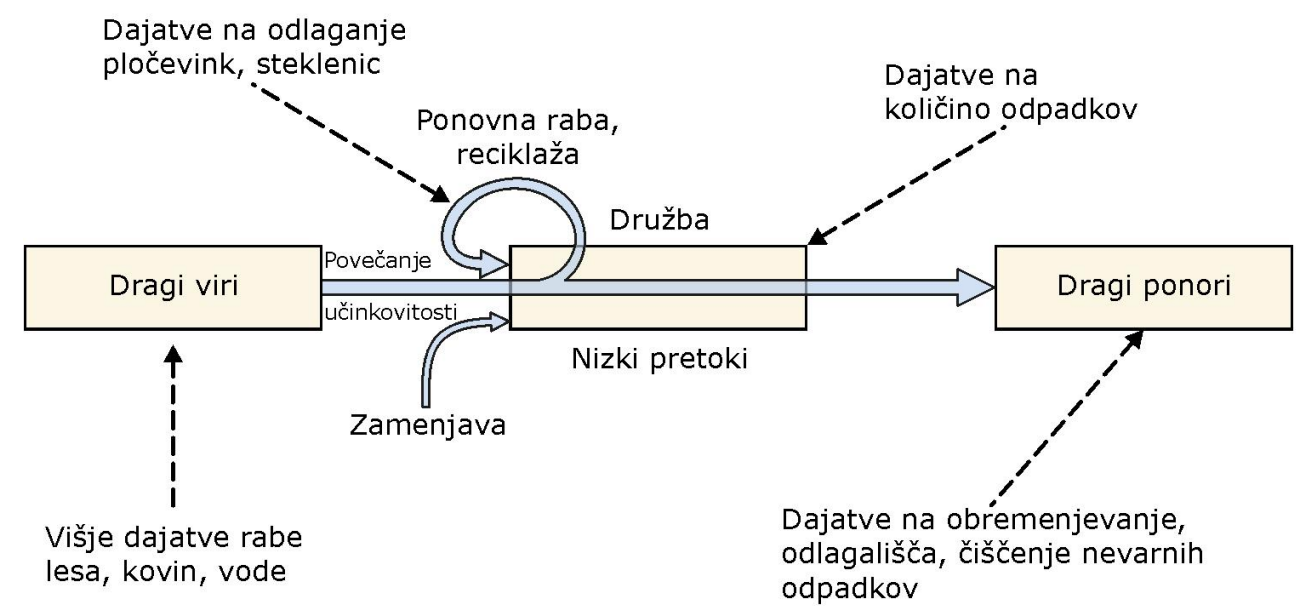

Oblikovanje: Andrej Herakovič

Okoljski ekonomisti želijo preseči tudi po njihovem prepričanju napačno dihotomijo med ekonomijo in ekologijo: »delo ali okolje«. Nasprotje obstoja le v omejenem obsegu in času, zato povezujejo kratkoročne potrebe po gospodarskem razvoju, delovnih mestih in dolgoročno potrebo zaščite okolja kot skupni cilj. Tako proizvodnja dobrin in storitev kot zaščita okolja imata enako težo, prioriteto. Okolju prijazne dejavnosti namesto velikih količin energije in strojev ustvarjajo več delovnih mest, saj so praviloma delovno intenzivne. Okoljski ekonomisti torej prepoznavajo potrebo trajnostno sonaravne, pretežno kakovostne gospodarske rasti, zasnovane na minimalni rabi virov, kontroli onesnaževanja okolja na viru in prehodu k rabi obnovljivih virov (McKinney in Schoch 1998, 582; Brown in Mitchell 1998, 209). 
McKinney in Schoch $(1998,580)$ sodita, da je potrebno svetovno trajnostno sonaravno ekonomijo zasnovati v naslednjih dveh desetletjih, ključni naj bi bili naslednji koraki:

1. povečan finančni priliv v države razvoja, ki naj nadomesti sedanji obratni tok;

2. preusmerjanje denarja $\mathrm{v}$ dejavnosti, ki so hkrati produktivne in trajnostno sonaravne;

3. zasnova socialnega reda, ki bo podpiral pravičen dostop in razdelitev blagostanja.

Najšibkejša točka "zelenih" ekonomistov (nekje na sredi med naravovarstveniki in neoklasiki) je, da ni potrebno ohranjanje nobenega vira blaginje posebej, ampak samo agregatno. To lahko sčasoma pripelje do ireverzibilnosti, z vse manjšim deležem okoljske blaginje v skupni blaginji, kar ogroža raznolikost blaginje (Radej, 2001b) in trajno delovanje planetarnega ekosistema.

\section{Šibka in močna (trda) GTS: različno vrednotenje (ne)zamenljivosti naravnega (okoljskega) kapitala}

Trajnostno sonaravni razvoj naj bi prihodnjim generacijam zapuščal enako ali po možnosti povečano zalogo okoljskega (naravnega), gospodarskega (fizičnega) in človeškega ter družbenega kapitala. Med posameznimi vrstami kapitala obstajajo tesne medsebojne povezave in soodvisnosti (Graf 10). Za GTS je torej ključno, da imajo prihodnje generacije na razpolago tolikšen kapital kot sedanja generacija. Skupni (agregatni) kapital sestavlja (The World Bank 1992, 8; Pearce 1994, 15; Šolar, 2004, 29):

a) naravni (okoljski) kapital - obnovljivi in neobnovljivi viri (tudi z vidika kakovosti), habitati, biotska raznovrstnost;

b) ustvarjen (fizični, gospodarski) kapital - hiše, stroji, infrastruktura;

c) človeški (in družbeni) kapital - znanje, sposobnosti, izkušnje, zdravje.

V širše pojmovanem naravnem kapitalu (okoljski kapital) so razen naravnih virov vključene tudi vse storitve okolja, fizični in človeški kapital pa se lahko označujeta kot ustvarjeni kapital. Zagovorniki GTS se glede opredeljevanja skupne količine in sestave kapitala za prihodnje generacije ločijo v dve skupini in sicer na zagovornike ti. šibke in močne oziroma stroge trajnostnosti/sonaravnosti (Haughton in Hunter 1994, 20; Barbier in drugi 1995, 55). Pripadniki šibke GTS sodijo, da gospodarska rast in varstvo okolja nista nepomirljivi nasprotji. Zagovarjajo stališče, da sicer sedanja generacija ne sme prihodnjim generacijam zmanjšati skupnega kapitala, vendar lahko zmanjševanje npr. naravnega kapitala nadomesti s hkratnim povečanjem ustvarjenega kapitala. Predstavniki šibke TS torej predpostavljajo možnosti zamenjave vseh oblik kapitala. Izhajajo iz podmene, da je možno »optimalno« izkoriščanje naravnega kapitala. Hkrati zagovarjajo okolju bolj prilagojeno, a trajno gospodarsko rast, ki omogoča odpravo svetovne revščine (Carley in Christie 1994). Tako stališče zastopa ti. Brundtlandina komisija za razvoj in okolje (World Commission on Environment...1987) ter Svetovna banka (The World Bank 1992). Zagovarjata predpostavko, da je v obdobju odpravljanja svetovne revščine nekatere oblike naravnega kapitala mogoče nadomestiti z drugimi oblikami kapitala (blagostanja), ključne ekološke sisteme pa je kljub 
temu potrebno zaščititi. Poročilo Brundtlandine komisije ZN o okolju in razvoju tako predvideva 5-10-kratno povečanje svetovnega gospodarstva v 21. stoletju (World Commission on Environment...1987). Okoljski realizem opozarja, da tako veliko povečanje svetovnega gospodarstva na sedanji, nesonaravni način, ni mogoče brez kolapsa svetovnega ekosistema, ekološko torej ni mogoče (Daly 1991b).

Graf 10: Povezava med posameznimi vrstami kapitala trajnostno sonaravnega razvoja

Figure 10: Relationship between different categories of capital of sustainable development

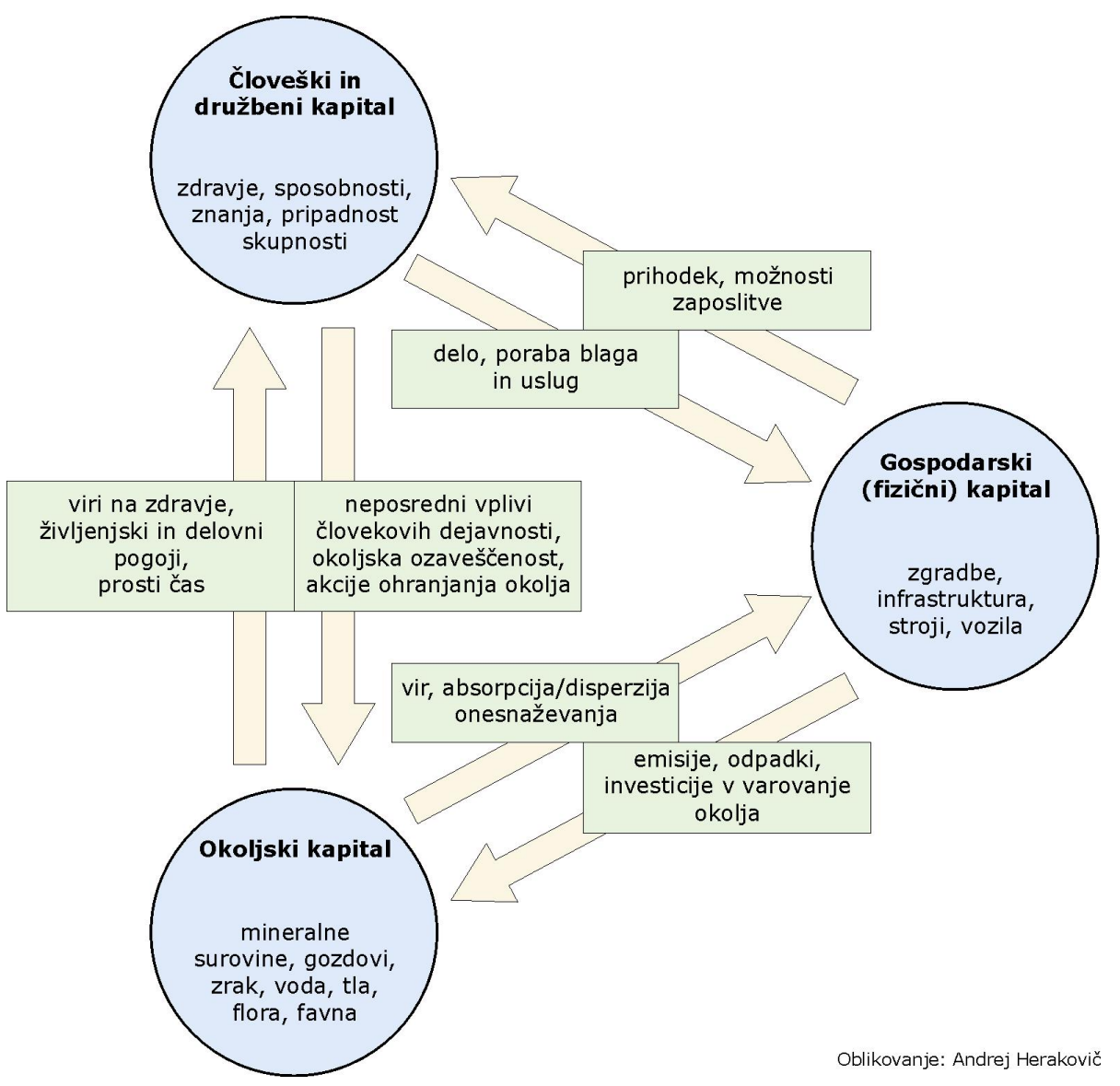

Tržni model po mnenju radikalnih okoljskih ekonomistov in ekologistov omogoča le šibko OTS, ohranjanje skupnega (družbenega) kapitala planeta, ki obsega naravni in ustvarjeni kapital. S pomočjo zakonskih (strožja okoljska zakonodaja), ekonomskih in planskih instrumentov (davki, internalizacija okoljskih stroškov itd.) lahko dosežemo zmanjševanje hitrosti izčrpavanja okoljskega kapitala, ki omogoča ohranjanje življenjskih pogojev. Okolje, viri okolja naj bi torej imeli svojo (realno) tržno ceno, ki jo je potrebno vključiti v ekonom- 
sko analizo. Radej (1992) izhaja iz predpostavke, da okoljsko deviantno delovanje trga zahteva državne tržno zasnovane mehanizme (najprej omejevalne-zakonske, nato stimulativneekonomske), ki bodo omogočili prenos stroškov degradacije okolja z ramen družbe (in narave-opomba avtorja) na povzročitelje onesnaževanja okolja.

Po mnenju Elliotta $(1994,110)$ koncept trajnostno sonaravnega razvoja izhaja iz prilagodljive zasnove kapitalističnega sistema glede okolja in razvoja in kot tak v tem civilizacijskem trenutku realno nima alternativnega koncepta. Tudi Gospodarska strategija Slovenije (2001) je zasnovana na zmanjševanju posameznih sestavin okoljskega kapitala in hkratnemu povečevanju drugih oblik ustvarjenega kapitala, torej izhaja iz paradigme šibke trajnostnosti/sonaravnosti..

Radikalni ekologisti pa so odločni zagovorniki načela močne (stroge) GTS saj sodijo, da sta gospodarska rast in zaščita okolja v nepomirljivem nasprotju in ne verjamejo, da je tehnološka rešitev degradacije okolja mogoča s pomočjo gospodarske rasti. Ekologisti izhajajo iz predpostavke o omejenosti možnosti zamenjave naravnega kapitala z ustvarjenimi oblikami kapitala. Nekatere oblike naravnega kapitala, ti. kritični naravni kapital (za blagostanje ali preživetje ter biotsko raznovrstnost) pa ni mogoče zamenjati z oblikami ustvarjenega kapitala (Pearce 1994, 16; Barbier in drugi 1995, 55). Prihodnjim generacijam je potrebno zapustiti enake zaloge kritičnega naravnega kapitala, npr. biotsko raznovrstnost (ne zgolj vrst, temveč habitate, ekosisteme), ozonski plašč itd, stabilno podnebje. Zaščita naravnega kapitala, biotske raznovrstnosti (medgeneracijska enakost), ekosistemskih storitev, je za strogo TS ključnega pomena. Smoter naravnih dobrin ni v njihovem črpanju za nadaljnjo predelavo, ampak predvsem vzdrževanje življenja v njegovi mnogoteri pojavnosti. Stroga TS torej omejuje nadomeščanje med nekaterimi viri blaginje, omejevanje s pomočjo obveznega (a selektivnega) ohranjanja rezervnih, minimalnih varnostnih zalog naravnih bogastev, npr. biotske raznovrstnosti in delovanja biogeokemičnih krogov (vodnega, prehrambenega in ogljikovega) (Radej, 2001b).

Stroge, močne GTS, torej ohranjanja zalog naravnega kapitala (naravnih virov) pa tržno zasnovan model gospodarstva naj ne bi zagotavljal oziroma omogočal. Sedanje netrajnostno stanje po mnenju Jacobsa $(1999,92)$ ni torej pomanjkljivost trga in neoklasičnega modela, temveč njegova ključna značilnost. Močno sonaravnost ni mogoče doseči s korekcijo trga, temveč $z$ odločitvijo o radikalno drugačnem prihodnjem razvojnem vzorcu. GTS lahko z vidika močne sonaravnosti opredelimo kot izbiro »ekološke rekonstrukcije«, preudarnih in temeljnih sprememb v sami strukturi gospodarske dejavnosti (in vseh sistemov družbe), ki bodo omogočili trajno ohranjanje vplivov na okolje znotraj ekosistemskih zmogljivosti (Jacobs 1999, 92).

Realno je pričakovanje, da bo tudi v predvidljivi prihodnosti svetovno (kapitalistično) gospodarstvo delovalo na osnovi trga, svetovni gospodarski razvoj pa naj bi potekal $v$ smeri od šibke k močno trajnostnosti. Zaradi velikih razlik v materialnem standardu med državami se naj bi bogate države osredotočile na dvig kakovosti življenja, revne države pa preživetje, odpravljanje revščine. Zato naj bi bila kakovostna razsežnost gospodarskega razvoja ključna za razvite države, zaradi odpravljanja revščine pa je v določenem obdobju v revnejših državah neobhodna količinska ekonomska rast (Elliott 1994). Z rastjo BDP na prebivalca se najprej postopoma stopnjuje pritisk javnosti za višjo kakovost življenja. Vedno večja 
javna osveščenost in skrb prebivalstva za zaščito okolja spreminjata želje potrošnikov po nakupih okolju prijaznih izdelkov, varstvo okolja odpira nove možnosti proizvodnje, storitev, odpira delovna mesta (Kovačič, 2001).

Sodelavci Evropske agencije za okolje (EEA 1999) pa izhajajo iz stališča, da je ključni kriterij za odločanje o rabi naravnega vira možnost oziroma odsotnost možnosti za hkratno nadomeščanje njegovih funkcij s pomočjo ustvarjenega kapitala. Če je nadomestilo možno, potem lahko TS dosežemo s pomočjo ohranjanja stabilnih zalog naravnega in ustvarjenega kapitala, torej s »šibko« sonaravnostjo. V kolikor pa zamenjava ni mogoče, npr. v primeru ekoloških funkcij stratosferske plasti ozona, potem je potrebno naravni kapital zaščititi, z »močno« sonaravnostjo (European Environment Agency 1999, 40).

\section{SOCIALNA (DRUŽBENA) TRAJNOSTNOST/SONARAVNOST - PRIMERNA KVALITETA ŽIVLJENJA ZA VSE V OKVIRU ZMOGLJIVOSTI OKOLJA}

V obdobju enostranskega razumevanja rasti BDP kot glavnega cilja razvoja se je predvidevalo, da bo kvaliteta življenja avtomatično sledila ekonomski rasti. Vendar je v 60. letih 20. stoletja zlasti v državah razvoja prihajalo do vse večje množice ljudi, ki niso bili udeleženi pri povečevanju materialnega standarda, rast BDP je hkrati povečevala socialno neenakost in izčrpavanje okolja (Seljak 2000). Tudi sodobno obdobje globalizacije gospodarstva kljub stalni nekaj odstotni rasti svetovnega BDP (nad stopnjo rasti svetovnega prebivalstva) ohranja približno enako število revnih po svetu, socialne razlike med državami in znotraj držav se povečujejo. $\mathrm{V}$ tržnem sistemu je svoboda posameznika v pridobivanju bogastva nad pravico drugih posameznikov po preživetju. Polje socialne politike v moderni državi pa naj ne bi bila samo socialna varnost, temveč širše pojmovana kvaliteta življenja, ki zahteva tako nadzor nad samim trgom, kot upravljanje vseh netržnih dejavnosti (šolstvo, zdravstvo itd.), pa tudi enakost pri pristopu do virov okolja, lokalno sodelovanje.

OST ključno opredeljuje integriteta ekosistemov in nosilnost okolja, GTS pa gospodarski razvoj v okviru omejitev okolja. Socialno, širše družbeno trajnostnost/sonaravnost (STS ali DTS) označuje v ožjem pomenu socialna varnost in pravičnost za vse prebivalce, $\mathrm{v}$ širšem pa težnja povečanja ali vsaj ohranjanja kakovosti življenja za vse prebivalce v okviru zmogljivosti okolja. Dejansko udejanjanje načela trajnostnosti na širše pojmovanem družbenem polju pomeni, da je sicer visoko kakovosti človekovega blagostanja potrebno doseči ob ohranjanju, izboljšanju blagostanja okolja (Graf 11) (Bell in Morse, 2003). Ožje pojmovanje odseva razmerje med razvojem in trenutnimi socialnimi normami (Munro 1995, 32). Dejavnost je socialno trajnostna, če je v skladu s socialnimi normami, zasnovanimi na tradiciji, običaji, religiji, veljavnimi etičnimi in vrednostnimi sistemi. Številne od navedenih socialnih norm je težko definirati in meriti, se spreminjajo $\mathrm{v}$ času in prostoru. Med sodobno in tradicionalno družbo so številne razlike v socialnih normah, tudi glede lastništva naravnih virov (zemljǐše, voda, živali) in odnosa do okolja.

Dolgoročno preživetje človeške vrste naj bi bil osnovni kriterij tudi za polje STS v trajnostno sonaravnem trikotniku okolje-ekonomija-družba (sociala). Temeljno polje STS 
delovanja je socialna varnost, kvantitativna skupina kazalcev STS meri npr. pričakovano trajanje življenjske dobe, zdravje, prehranjevanje, bivanje, razdelitev dohodka in druge vidike socialnega in kulturnega življenja. Socialna varnost za vse prebivalce sveta mora biti dosežena na način, ki ne ogroža preživetja in napredka prihodnjih generacij. Ekonomska aktivnost je torej nujna za delovanje človeške družbe, a le kot sredstvo za človekov razvoj in napredek (kvaliteto življenja), ki vključuje poleg dostojnega materialnega standarda za vse ljudi in varstva okolja tudi socialne in kulturne vrednote. Ključna je enakost v dostopnosti do virov, ki zagotavljajo socialno varnost. Stopnja revščine, socialno izključevanje in brezposelnost so pomembni kazalci socialne varnosti oziroma ogroženosti, regionalne razlike pa kažejo razen ekonomskega tudi socialni vidik razvoja (Poročilo o človekovem... 1998).

Slika 11: Barometer trajnostnosti/sonaravnosti

Figure 11: Barometer of sustainability

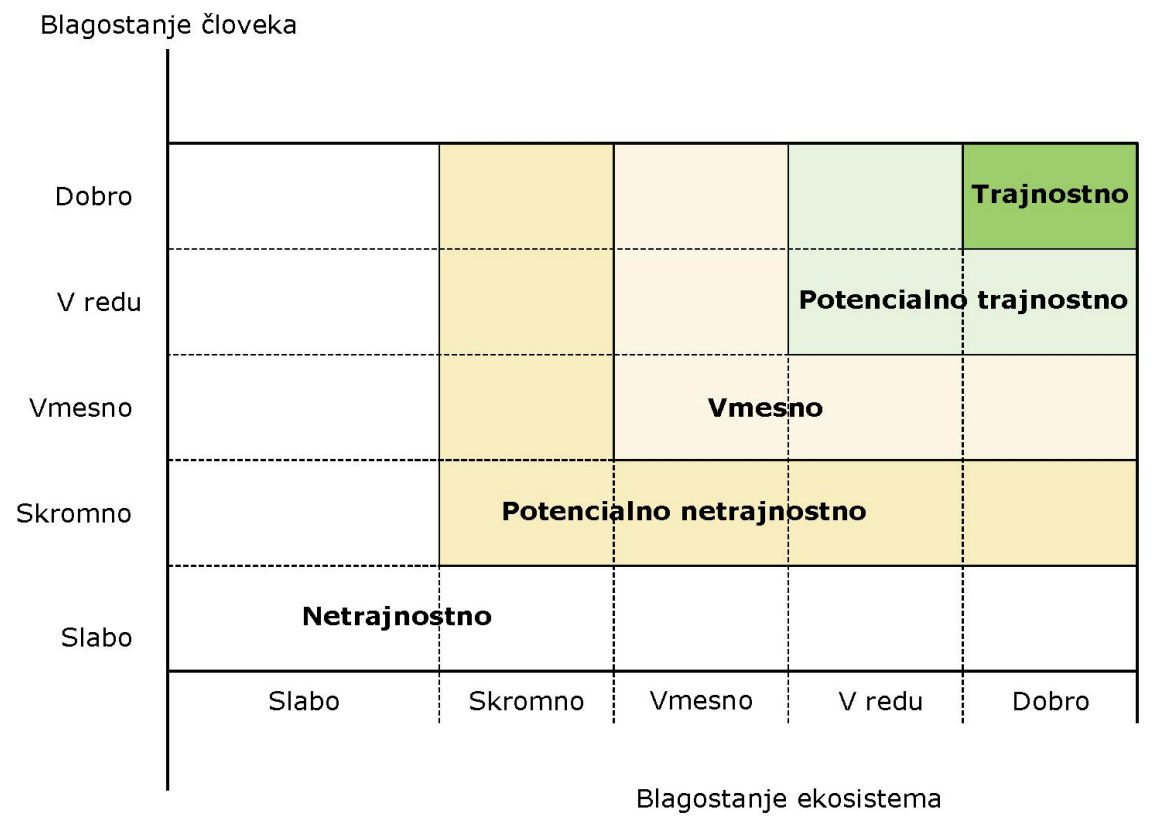

Oblikovanje: Andrej Herakovič

Osnovni kazalec spremljanja na področju zdravja je pričakovano trajanje življenja, na področju prehrane količina kalorij oziroma odstotek potrebne količine kalorij (okoli 2400 kcal na dan na osebo), med kazalci izobraževanja pa povprečno število let šolanja. STS je torej tesno povezana in odvisna od OTS in GTS. Tako je propadanje nekaterih industrijskih panog ali mest izboljšalo kakovost okolja in hkrati povečalo socialno stisko prizadetih prebivalcev. V številnih primerih pa je nujno gospodarsko prenovo spremljalo izboljšanje kakovosti bivalnega okolja in hkrati večja socialna varnost prebivalcev (Townroe 1996). 
Izraz »kvaliteta življenja« ne vključuje zgolj materialne in socialne varnosti, označuje širšo, družbeno pojmovanje trajnostnosti. Označuje koncept, ki vključuje tudi mir, srečo, enake možnosti, osebno zadovoljstvo (Seljak 2000, 100). Širok dostop prebivalcev do zaposlitve, izobrazbe, zdravstvenega varstva, stanovanja naj bi pomembno označeval STS, družbeno integracijo (kohezijo). Sklerozno obnašanje institucij lahko zelo poveča družbeno neenakost $\mathrm{v}$ dostopu do služb, izključenost določenih skupin prebivalcev kljub skupnemu povečanju dohodkov določenega območja, mesta (Townroe 1996). Opredelitev socialnega (družbenega) razvoja je $\mathrm{v}$ bistveno odvisna od prevladujočih vrednot, kulture $\mathrm{v}$ širšem pomenu. V tržnem sistemu je svoboda posameznika $v$ pridobivanju bogastva nad pravico drugih posameznikov po preživetju. Eden od osnovnih ciljev STS naj bi bila vsaj zamenjava teh dveh prioritet oziroma postaviti delovanju trga in njegovim najmočnejšim udeležencem omejitve. Družbena (ožje socialna) integracija je mogoča le ob družbeno sprejemljivi dohodkovni neenakosti. Prevelike razlike $\mathrm{v}$ dohodkih zavirajo tako ekonomsko rast kot družbeno kohezijo (Poročilo o človekovem... 1998, 11). Tudi številni varstveni biologi so prepričani, da je tudi za uspešno varstvo biodiverzitete treba ljudem najprej zagotoviti ustrezne življenjske razmere, kar v najširšem smislu pomeni prerazporeditev bogastva v globalnih razmerah (Kryštufek 1999, 8).

Pravičnost je normativen etični pojem za opredeljevanje ravnanja osebnosti, ki ustreza časovno dinamičnemu sistemu moralnih norm in vrednot. V konceptu trajnostnost/sonaravnost je $\mathrm{v}$ središču znotrajgeneracijska in medgeneracijska pravičnost in enakost ter $\mathrm{v}$ obeh odnos do narave oziroma do drugih bitij (Seljak 2000). Revščina (absolutna in relativna) in množično umiranje ljudi po svetu zaradi lakote sta najbolj drastična kazalca družbene neenakosti oziroma nedoseganja STS sedanje generacije, izčrpavanje naravnega kapitala planeta pa kazalec medgeneracijske neenakosti. Prekomerna potrošnja najbogatejših slojev človeštva povzroča prekomerno obremenjevanje planetarnega okolja, obenem pa najrevnejši sloji ne morejo zadovoljevati osnovnih materialnih potreb. Vsak okoljski (ne)trajnostnosti in (ne)sonaravni ukrep bo povzročil prerazporeditev stroškov in koristi v prostoru (geografsko) in času (medgeneracijsko). To povzroča številna etična, vrednostna in kulturološka vprašanja in razumevanje razmerja med posameznikom in družbo. STS se ne strinja z neoklasično ekonomsko predpostavko, da lahko zadovoljstvo in srečo doseženo zgolj z maksimalno materialno potrošnjo.

V razliko od prejšnjih generacij živi sedanja v obdobju prvih znakov planetarne krize okolja. Socialno varnost, višjo kakovost življenja sedanje generacije je potrebno doseči brez slabšanja kakovosti življenja prihodnjih generacij. Pripadnikom obstoječe generacije je potrebno omogočiti enakopravnejši dostop do virov ter doseganje optimalnega (ne pa maksimalnega) materialnega blagostanja. Napredek v smeri STS pomeni hkrati razvoj nove filozofske in vrednostne osnove, do okolja in prihodnjih generacij odgovorne etike za organiziranje globalne ekonomije, nacionalnih in regionalnih gospodarstev ter načina življenja posameznika, gospodinjstva (Clayton in Radclift 1996). Sedanja generacija naj ne bi imela moralne pravice naprtiti prihodnjim generacijam posledice nesonaravnega načina življenja in npr. povzročati izumiranje vrst.

Pod etični vprašaj se torej postavlja tudi življenjski slog, ki se je po drugi svetovni vojni uveljavil v gospodarsko razvitih državah. Materialni življenjski standard, ki presega 
temeljne potrebe, je sprejemljiv edino, če dolgoročno ne ogroža kateregakoli območja sveta in prihodnjih generacij. Potrebe pa so družbeno sprejemljive, če ne presegajo raven potrošnje, za katero je razumno pričakovati, da bo za vse dosegljiva (Dekleva 1992). Univerzalnost človekovih potreb terja razvoj mednarodnega sistema, ki bo izhajal iz dejstva, da je le ena Zemlja in omejena količina javnih dobrin za več generacij.

STS odpira torej vprašanje planetarno zasnovane družbene pravičnosti (varnosti), enakosti, solidarnosti, znotrajgeneracijske okoljske pravičnosti (enaka pravica dostopa do virov) in medgeneracijske odgovornosti. Temeljno jo označuje naslednja etična premisa: ljudje so enakopravni, kjerkoli in kdajkoli živijo (Achterberg 1999). Državi, regiji, posamezniku pripadajočo količino oziroma delež okoljskega prostora presegamo takrat, ko obseg rabe virov okoljskega prostora ni zasnovan na okoljski trajnostnosti/sonaravnosti in družbeni pravičnosti. Vsak prebivalcev planeta ima enako pravico do deleža naravnih virov in količine onesnaževanja okolja, ki ne sme ogrožati trajno delovanje ekosistemov in s tem potreb prihodnjih generacij (Hille 1997). Rast svetovnega prebivalstva in potrošnje na prebivalca sta ključna vzroka povečanja pritiskov na življenjske oskrbne zmogljivosti planeta (Agenda 21 1992, 35). Neenakost v dostopu do naravnih virov vpliva na prihodnost trajnostno sonaravnega razvoja. Tako revni prebivalci, ki nimajo druge možnosti, uničujejo bazo naravnih virov, uporabljajo naravne vire v smeri velikega obremenjevanja okolja, hkrati pa prihaja do selitev v velika mesta in območja ranljivih ekosistemov (gorska območja, gozdni ekosistemi) (Elliott 1994).

STS odraža tudi razmerje med razvojem in obstoječimi socialnimi normami. Dejavnost je trajnostno sonaravna, če je v skladu s socialnimi normami oziroma ne seže preko tolerance skupnosti glede spremembe (Munro 1995, 32). Socialne (družbene) norme pa so zasnovane na religiji, tradiciji, etiki, sistemu vrednost, izobraženosti, lahko pa so zakonsko opredeljene. Večino socialnih norm težko definiramo, merimo in vrednotimo, hkrati pa se hitro spreminjajo. Obnašanje, ki je v določenem obdobju nespremenljivo, lahko kmalu postane popolnoma spremenljivo. V številnih tradicionalnih družbah je vrednotenje naravnega okolja, kot celote ali njegovih sestavin (voda, drevesa, živali) zelo visoko. V številnih skupnostih so ti viri skupna last, pravice njihove rabe pa neprenosljive. V kriznih obdobjih je volja za zaščito skupnih dobrin potisnjena v ozadje (Munro 1995, 32).

Za spremljanje (ne)uspešnosti udejanja medgeneracijske enakosti bi bilo potrebno razviti medgeneracijsko uporaben indeks potrošnje oziroma indeks blagostanja, npr. sestavljen kazalec potrošnje na prebivalca. Upoštevati pa je potrebno tudi porazdelitev potrošnje med prebivalci. Družba kot celota lahko doseže višjo raven splošnega blagostanja, razlike med prebivalci v razporeditvi tega blagostanja pa se še povečajo. Odgovornost medgeneracijske enakosti je torej potrebno povezati s povečevanjem znotrajgeneracijske enakosti. Napredek v smeri med- in znotrajgeneracijske enakosti bo zahteval izračune stroškov, okoljskih posledic in koristi za vsak korak posebej. Povečevanje medgeneracijske enakosti zahteva planetarni pristop, trajno planetarno prilagoditev porabe naravnih virov in obremenjevanja okolja zmogljivostim planetarnega ekosistema. Znotrajgeneracijska enakost pa zahteva zmanjševanje socialnih in regionalnih razlik hkrati z bistvenim zmanjšanjem sedanje potrošnje naravnih virov in onesnaževanja okolja v bogatih državah. 


\section{TRAJNOSTNO SONARAVNI NAPREDEK KOT OKOLJSKA, GOSPODARSKA IN DRUŽBENA (SOCIALNA) OPTIMALNOST}

Za načrtovanje udejanjanja okoljske, gospodarske in socialne (družbene) trajnostnosti so ključne: a) potrebe človeka, b) okoljske omejitve c) gospodarsko-socialna varnost in d) medgeneracijska pravičnost (odgovornost). Civilizacijska sporočilna nota trajnostnostno sonaravne paradigme je dejansko zelo radikalna, saj celotno dosedanjo zgodovino človeške vrste ključno označuje kolonizacija in količinska rast, odsotnost intelektualnih ali institucionalnih zmogljivosti za doseganje ravnovesja med materialnimi potrebami človeštva in zmogljivostjo narave, znotraj- in med-generacijska neenakost. Kolonizacijski gospodarski razvoj človeštva ni zadovoljil niti eksistenčnih potreb vseh prebivalcev planeta, hkrati pa načenja biološke pogoje življenja samega. Koncept razvoja v klasičnem pomenu predpostavlja rast, koncept trajnostnosti ohranjanja pogojev življenja pa je zasnovan na izhodišču, da rast ni mogoča na omejenem planetu. Potrebujemo torej tak koncept, način optimalnega gospodarskega in socialnega razvoja, ki bo upošteval naravno ravnovesje in omejitve (bolje zmogljivosti), torej ne bo zasnovan na neskončni količinski rasti. Po mnenju Kovača (1986) je realna dolgoročna alternativa kvalitetno opredeljena gospodarska rast (gospodarski razvoj), ki ne izključuje varstvo okolja.

Tako trajnostno sonaravna paradigma prinaša zahtevo, da naj potrebno povečevanje kakovosti življenja zlasti socialno šibkih poteka brez prelaganja stroškov okolja na prihodnjo generacijo. Zaščita naravnih virov in okolja, naravne dediščine je torej ključna osnova za doseganje trajnostno sonaravnega razvoja (Pearce 1994; Leveque in Mounolou 2003). Okoljska politika kot »politika politik «, torej kot integralna sestavina gospodarskih in drugih politik, je po mnenju strokovnjakov Evropske agencije za okolje (EEA 1999, 19) temeljni instrument trajnostno sonaravnega razvoja.

Časovno razsežnost, trajnostnost kot medgeneracijsko odgovornost in planetarna enakost prebivalcev (socialna in etična razsežnost) pa sta se konceptu okolje-razvoj dodala $\mathrm{v}$ drugi polovici 80. let. Tako je v poročilu "Our Common Future" (World Commission on Environment...1987) Svetovne komisije za okolje in razvoj pri OZN, ki jo je vodila takratna predsednica norveške vlade ga. Brundtlandova, koncept okolje-razvoj vključil gospodarske, okoljske, socialne in etične razsežnosti ter postal na konferenci OZN o okolju in razvoju leta 1992 v Rio de Janeiru civilizacijska razvojna paradigma za 21. stoletje. Komisija verjame, da bodo primerne spremembe tehnologij in organiziranosti družbe omogočile novo obdobje gospodarske rasti, ki pa ne sme ogroziti ključne oskrbne naravne sisteme Zemlje (ozračje, vode, prsti in biosfero) (World Commission on Environment...1987).

V splošnem naj bi načelo trajnostnosti argumentiralo potrebo po nadaljevanju gospodarskega razvoja in hkrati varstva okolja, in sicer bolj z vidika povezanosti in ne kot nepomirljivo nasprotje. Sam pojem pa dejansko vsebuje nasprotje, saj združuje razvojni in varovalni vidik. Načelo trajnosti samo po sebi ne more zagotoviti nekonfliktnosti med varstvom in razvojem. Postavljeno je namreč v obliki cilja, v obliki načela, ko ( ̌̌e) ne poznamo možnosti njegovega uresničevanja (Marušič 1996, 52). To pomeni težavno in zahtevno usklajevanje teženj gospodarskega in družbenega razvoja ter varovanja in izboljšanja okolja ter 
narave. Sistem oziroma proces je trajnosten, v kolikor lahko traja neskončno, brez izčrpavanja materiala ali energetskih virov, ki so potrebni za pogon družbe (Nebel in Wright 1998, 14). Razvoj pojmujemo kot trajnosten takrat, ko se njegove koristi pojavljajo neskončno dolgo. To pomeni, da v procesih dejavnosti ne sme biti prisotno nič takega, kar bi omejilo čas delovanja, zato je potrebno predvideti posledice (tveganja) delovanja $\mathrm{v}$ prihodnosti (Munro 1995, 28). Načelo trajnostnosti razen potrebe integriranega upravljanja z okoljem in naravnimi viri poudarja pomen ohranjanja biološke raznovrstnosti (biodiverzitete), katero je mogoče učinkoviti zaščititi zgolj $\mathrm{v}$ dobro delujočih ekosistemih (Leveque in Mounolou 2003, 239).

Trajnostno sonaravni napredek (TSN) ključno označuje integracija, nujnost hkratnosti in enakopravnosti ter optimalnosti doseganja vseh treh ključnih ciljev (Preglednica 2):

1. gospodarski napredek-izboljšanje materialnega blagostanja;

2. družbeni (ožje socialni) napredek-izboljšanje socialne varnosti, kakovosti življenja in zmanjšanje socialnih ter regionalnih razlik v sedanji generaciji (družbena kohezija);

3. okoljski napredek- izboljšanje stanja okolja, ohranjanje okoljskega kapitala in ohranjanje življenjskih pogojev za kakovostni humani napredek prihodnjih generacij.

Preglednica 2: Ključna polja, cilji in smernice sonaravnega napredka

Table 2: Key fields, objectives and guidelines of sustainable development.

\begin{tabular}{|c|c|c|}
\hline $\begin{array}{l}\text { Polja sonaravnega } \\
\text { napredka }\end{array}$ & $\begin{array}{l}\text { Cilji polj sonaravnega } \\
\text { napredka }\end{array}$ & Smernice sonaravnega napredka \\
\hline $\begin{array}{l}\text { Gospodarski } \\
\text { napredek }\end{array}$ & $\begin{array}{l}\text { Izboljšanje material- } \\
\text { nega blagostanja }\end{array}$ & $\begin{array}{ll}\text { - } & \text { gospodarski razvoj v okviru nosilnosti virov } \\
\text { in okolja } \\
\text { - } \quad \text { čim krajše prehodno obdobje (šibka sonarav- } \\
\text { nost dejavnosti) zamenjave naravnega kapitala } \\
\text { z ustvarjenim } \\
\text { - } \quad \text { vključitev okoljskih škod v ceno proizvoda in } \\
\text { storitev } \\
\text { financiranje, razvoj in uporaba okoljsko } \\
\text { najbolj primernih industrijskih in drugih tehno- } \\
\text { logij } \\
\text { skladnejši (regionalno) gospodarski razvoj }\end{array}$ \\
\hline $\begin{array}{l}\text { Družbeni (ožje } \\
\text { socialni) napredek }\end{array}$ & $\begin{array}{l}\text { Kvaliteta življenja, } \\
\text { socialna varnost vseh } \\
\text { prebivalcev sedanje in } \\
\text { prihodnjih generacij }\end{array}$ & $\begin{array}{l}\text { - } \quad \text { zagotavljanje človeka vredne kakovosti } \\
\text { življenja vsem sedanjim in prihodnjim prebi- } \\
\text { valcem, zadovoljevanje osnovnih potreb } \\
\text { visoka stopnja socialne varnosti za vse } \\
\text { prebivalce } \\
\text { povečevanje lokalne samouprave, samozadost- } \\
\text { nosti in aktivnega sodelovanja prebivalcev }\end{array}$ \\
\hline Okoljski napredek & $\begin{array}{l}\text { Zdravo okolje in ohra- } \\
\text { njena narava (naravni } \\
\text { oziroma okoljski } \\
\text { kapital) za sedanjo in } \\
\text { prihodnje generacije }\end{array}$ & $\begin{array}{l}\text { - } \quad \text { zdravstveno sprejemljiva kakovost sestavin } \\
\text { bivalnega okolja } \\
\text { - } \quad \text { prehod na rabo obnovljivih virov v okviru } \\
\text { zmogljivosti obnavljanja } \\
\text { - ohranjanje naravnih vrednot in biotske pestros- } \\
\text { ti }\end{array}$ \\
\hline
\end{tabular}


Uporaba besede napredek namesto razvoj je primernejša zaradi dejstva, da se oznaka razvoj praviloma povezuje ali celo enači s količinsko zasnovano (gospodarsko) rastjo in s tem povezanim dvigom BDP. Trajnostno sonaravni napredek človeštva in vsakega posameznika pa naj bi bil oznaka za kakovostno zasnovano izboljšanje vseh treh temeljnih sestavin blaginje, brez izčrpavanja okoljskega kapitala. Carley in Christie $(1994,46)$ zato upravičeno opozarjata na prisotno, napačno pojmovanje, da je beseda »rast« sinonim za povečanje blagostanja, kakovosti življenja. V kolikor nas gospodarska rast pripelje v območje nad optimalno točko glede delovanja biosfere, dejansko postajamo vse revnejši (Graf 12). Območje med točkama S in D lahko opredelimo kot območje trajnostnega sonaravnega napredka, $\mathrm{v}$ katererem prednosti sodobne znanosti, izobraževanja in medicine omogočajo primeren dohodek, maksimum kakovosti življenja v prijaznem, zdravem okolju.

\section{Graf 12: Dohodek in kakovost življenja}

Figure 12: Income and quality of life

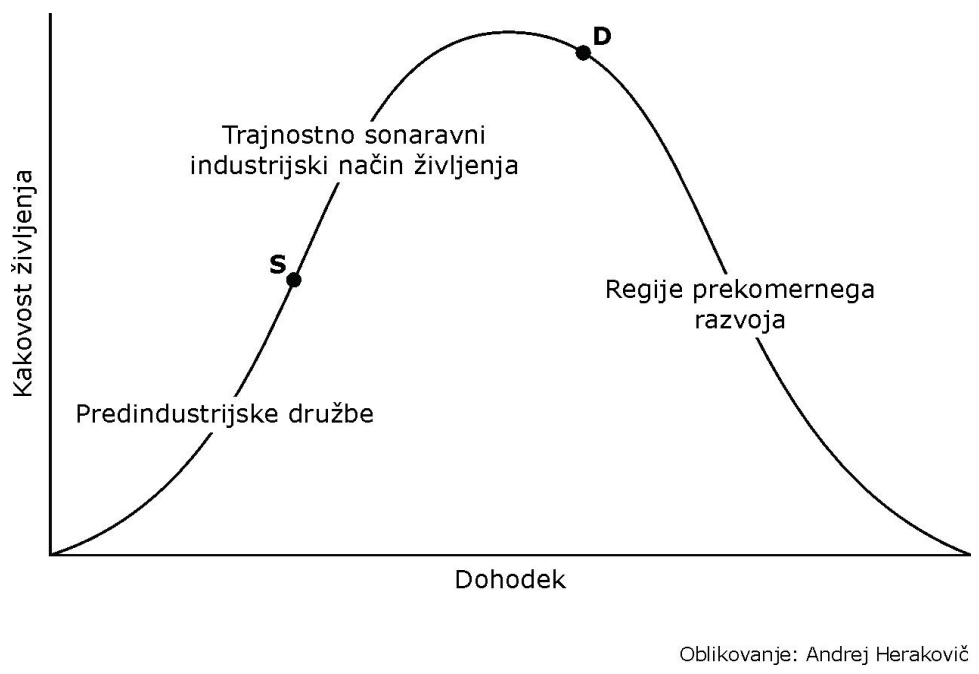

Širše pojmovanje napredka in kakovosti življenja naj bi pogojevalo tudi temu primeren izbor kazalcev za oznako stanja in spremljanje sprememb sestavin kakovosti življenja, napredka. Temeljni, količinsko opredeljeni kazalci udejanjanja trajnostno sonaravnega napredka naj bi omogočali objektivnejše spremljanje gospodarskega, družbenega (socialnega) in okoljskega napredka (Preglednica 3). V razliko od tradicionalnega kazalca gospodarskega razvoja (BDP) je niz trajnostno sonaravnih kazalcev gospodarskega napredka osredotočen na merjenje in spremljanje trendov gospodarske uspešnosti z vidika učinkovite rabe in obremenjevanja virov okolja. Kazalci družbenega napredka merijo različne sestavine kakovosti življenja vseh prebivalcev, s poudarkom na kazalcih socialne varnosti in družbene enakosti. Okoljski napredek, kakovost okolja in ohranjanje naravnega (okoljskega) kapitala merijo okoljski kazalci stanja, pritiskov in odzivov (odgovorov) družbe na okoljske probleme. 
Preglednica 3: Temeljni kazalci udejanjanja trajnostno sonaravnega napredka

Table 3: Basic indicators of adhering to sustainable close to nature managed development.

\begin{tabular}{|c|c|}
\hline $\begin{array}{l}\text { Polja } \\
\text { sonaravnega } \\
\text { napredka }\end{array}$ & Osnovni kazalci sonaravnega napredka \\
\hline $\begin{array}{l}\text { Gospodarski } \\
\text { napredek }\end{array}$ & $\begin{array}{ll}- & \text { BDP in »zeleni« BDP na prebivalca } \\
\text { - } & \text { energetska intenzivnost (poraba energije na enoto BDP, dodane vrednosti) } \\
\text { - } & \text { materialna intenzivnost (porabe kovin na enoto BDP, dodane vrednosti) } \\
\text { - } & \text { emisijska intenzivnost (plinska, tekoča, odpadki) (količina različnih emisij na } \\
& \text { enoto BDP, dodane vrednosti) } \\
\text { - } & \text { prostorska intenzivnost (\% pozidanega prostora) } \\
\text { - } & \text { delež podjetij z ISO } 14001, \text { EMAS in podobnimi okoljskimi standardi }\end{array}$ \\
\hline $\begin{array}{l}\text { Družbeni } \\
\text { napredek }\end{array}$ & $\begin{array}{ll}\text { - } & \text { indeks humanega razvoja } \\
\text { - } & \text { pričakovano trajanje življenja } \\
\text { - } & \text { povprečno število let šolanja na prebivalca } \\
\text { - } & \text { razmerje v dohodku } 20 \% \text { najbolj bogatih in } 20 \% \text { najbolj revnih gospodinjstev } \\
\text { - } & \text { delež revnih prebivalcev (relativna rev̌̌čina) } \\
\text { - } & \text { gibanje števila prebivalstva } \\
\text { - } & \text { indeks staranja } \\
\text { - } & \text { delež prebivalcev, vključenih v različna društva in druge dejavnosti } \\
\text { - } & \text { delež prebivalcev, ki so zadovoljni s kakovostjo življenja } \\
\end{array}$ \\
\hline $\begin{array}{l}\text { Okoljski } \\
\text { napredek }\end{array}$ & $\begin{array}{ll}\text { - } & \text { ekološke stopinje na prebivalca }\left(\mathrm{P}^{*}\right) \\
\text { - } & \text { poraba energije na prebivalca }(\mathrm{P}) \\
\text { - } & \text { količina komunalnih odpadkov na prebivalca }(\mathrm{P}) \\
\text { - } & \text { pokrajinska raba (npr. \% odprtega prostora) }(\mathrm{P}) \\
\text { - } & \text { emisije (plinske, tekoče, trdne) na prebivalca }(\mathrm{P}) \\
\text { - } & \text { kakovost sestavin okolja-imisije: (zrak, voda, prst, vegetacija) }(\mathrm{S}) \\
\text { - } & \text { število in deleži izumrlih in ogroženih vrst (S) } \\
\text { - } & \text { raba obnovljivih naravnih virov (\% v skupni porabi energije) (O) } \\
\text { - } & \text { delež reciklaže komunalnih odpadkov }(\mathrm{O}) \\
\text { - } & \text { učinkovitost čiščenja odpadne vode }(\mathrm{O}) \\
\text { - } & \text { učinkovitost zmanjševanja zračnih emisij }(\mathrm{O}) \\
\text { - } & \text { delež prebivalcev, ki uporablja javni promet }(\mathrm{O}) \\
\text { - } & \text { delež zavarovanih površin (kategorije IUCN, Natura 2000) }(\mathrm{O}) \\
\text { - } & \text { delež okoljskih sredstev v BDP }(\mathrm{O}) \\
\end{array}$ \\
\hline
\end{tabular}

$* P=$ kazalec pritiskov na okolje; $S=$ kazalec stanja okolja; $O=$ kazalec odzivov na okoljske probleme

Koncept TSN je drugačen od ideje vračanja v daljno preteklost na osnovi »živeti v harmoniji z naravo«. Potrebno je poudariti, da so ljudje v preteklosti v večini živeli neudobno, v pomanjkanju, z visoko stopnjo smrtnosti in kratko življenjsko dobo. Prehod v družbo sonaravnosti (trajnostnosti) ni zasnovan na posnemanju preteklih civilizacijskih vzorcev. Predstavlja nov civilizacijski izziv in model napredka, zasnovan na ideji o skrbništvu človeka do Zemlje, drugih vrst, na temu primerni stalni rasti znanosti, tehnologij kulture in duhovnega razumevanja našega mesta $v$ vesolju (Nebel in Wright 1998, 17). Okoljska trajnostnost/ 
sonaravnost pa po mnenju Viedermana (1995) ne zahteva globalne ekonomske integracije, neoliberalno zasnovane trgovinske politike nadnacionalnih podjetij, ki okolje pojmujejo zgolj kot »oviro« trgovanju. Poudarja pomen visoke stopnje ekonomske decentralizacije, zaščito okolja, virov, vrst (Viederman 1995). Leveque in Mounolou (2003) sodita, da vsaj teoretično zahodni model razvoja ni izključni in neobhodni model za družbeni (socialni) razvoj. Različne oblike razvoja naj bi bile usklajene z naravno (biotsko) in kulturno mozaičnostjo sveta. Vendar je večplastna globalizacija proces, ki je vse bolj intenziven, sega pa tudi na polje okolja kot okoljska globalizacija. Trajnostno sonaravna družba bo torej morala upoštevati vpetost $\mathrm{v}$ globalizacijske procese, jih okoljsko, regionalno in socialno uravnotežiti.

Pogoji za upravičenost oznake sonaravna družba (večja krožnost proizvodnih in potrošniških procesov namesto sedanjih prevladujočih linearnih) so naslednji (Bell in Morse, 2003, 6):

1. materiali zemeljske skorje se $\mathrm{v}$ ekosferi ne smejo sistematično (trajno) povečevati;

2. materiali, ki jih proizvaja družba v ekosferi ne smejo sistematično naraščati;

3. fizična osnova produktivnosti in raznovrstnosti narave se ne sme sistematično izčrpavati;

4. pravična in učinkovita raba virov mora upoštevati zadovoljevanje človekovih potreb.

Sonaravna družba torej označuje družbo udejanjanja trajnostnosti na okoljskem polju. Trajnostna (trajnostno-sonaravna) družba pa je družba človeka vrednega materialnega blagostanja in kakovosti življenja ter socialne varnosti v zdravem okolju, brez ogrožanja pogojev preživetja in napredka prihodnjih generacij ter biosfere.

$Z$ vidika udejanjanja koncepta trajnostnosti in TSN je trajnostno sonaravna družba tista, ki se a) nadaljuje iz generacije $v$ generacijo b) brez izčrpavanja baze virov s preseganjem trajnostnega donosa ali proizvodnje onesnaževanja nad naravno zmogljivostjo njihove absorpcije (Nebel in Wright 1998, 14). Označuje družbo, ki deluje v smeri, da ne izčrpava virov surovin in energije, od katerih je odvisna. Trajnostno sonaravna družba je družba, ki se je naučila živeti znotraj omejitev okolja, torej je ključna OTS, zlasti zasnova materialnega delovanja družbe na osnovi principa a) previdnosti in b) povratnosti (brez nepovratnih sprememb okolja) (Viederman 1995). Zasnovana je na rabi obnovljivih naravnih virov, stabilni ravni prebivalstva in materialnih tokov ter ohranjanju življenjskih podpornih sistemov (Meadowscroft 1999, 15). Njena ekonomska in tehnološka osnova sta trajnostno sonaravno gospodarstvo in trajnostno sonaravna tehnologija. Trajnostno sonaravna ekonomija omogoča blagostanje in zaposlitev številnih generacij brez degradacije okolja. Trajnostno sonaravna tehnologija pa omogoča človeštvu zadovoljevanje potreb z minimalnimi vplivi na okolje (McKinney in Schoch 1998) Zmanjšanje vnosov naravnih virov (skupnih materialnih tokov-domačih in uvoženih mineralov, fosilnih goriv, biomase) v materialne dejavnosti kot preventivni ukrep neposredno zmanjša iznose (vključno z emisijami in odpadki) in pritiske na okolje. Posebej pomembno je zmanjševanje porabe zalog naravnih virov in povečanje produktivnosti materialov in energije, torej dvig blagostanja hkrati z manjšo porabo naravnih virov (dematerializacija gospodarstva) kot ukrep močne sonaravnosti (Europe's Environment, 2003). Upravljanje z preostalimi vnosi z okoljem pa predstavlja osrednji kurativni okoljski ukrep. V ospredju so različni načini zmanjševanja negativnih okoljskih posledic proizvedenih emisij, odpadkov, odpadnih vod (Graf 13). 
Graf 13: Načini zmanjševanja onesnaževanja okolja

Figure 13: Methods for reducing environmental contamination

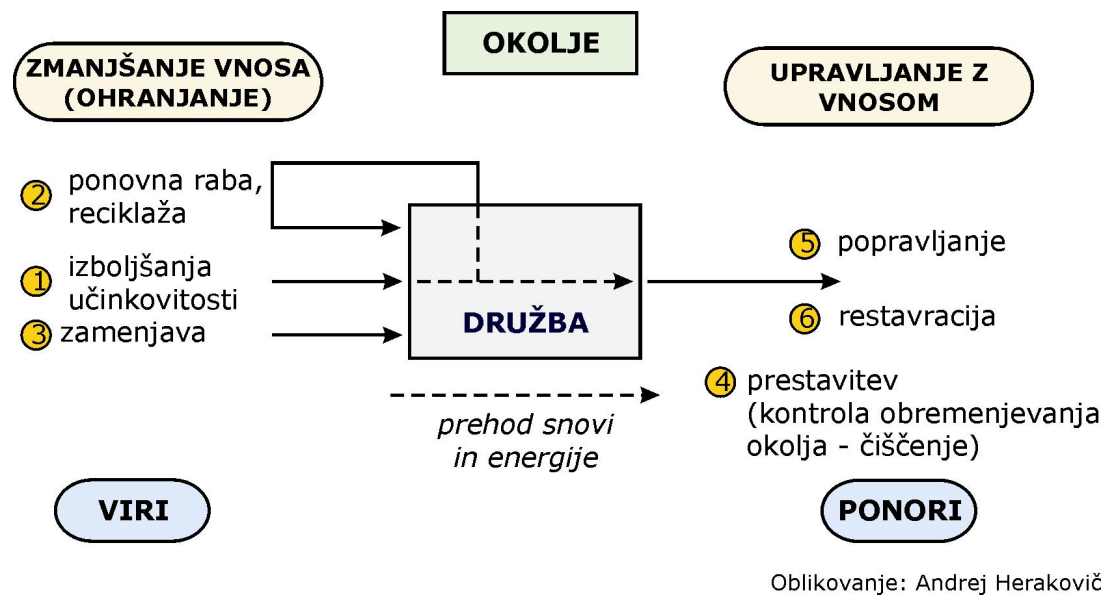

Trajnostno sonaravna družba naj bi bila okoljsko znotraj- in med-generacijsko odgovorna, socialno varna in pravična, gospodarsko uspešna, nenasilna do sočloveka (svetovni mir) in drugih vrst, zagotavljala naj bi dvig kakovosti življenja, humani napredek znotraj omejitev okolja (ekosistemov). Enostransko doseganje določenega cilja, npr. dvig dohodka na račun povečanja obremenjevanja okolja in izčrpavanja naravnih virov ter povečanja socialnih ter regionalnih razlik, prepada med bogatim Severom in revnim Jugom ni značilnost trajnostno sonaravne družbe. Prav tako ni trajnostno sonaravna družba tista, ki jo označuje ohranjeno okolje in hkrati revščina prebivalstva. Na družbenem, socialnem polju je torej ključni cilj povečana kvaliteta življenja vsakega posameznika. Na planetu, kjer nekateri posamezniki zaslužijo več kot milijon prebivalcev revnih držav in ljudje umirajo od lakote, je nekaj močno narobe s temeljnimi etičnimi vrednotami, na katerih temeljijo gospodarski in tudi vsi drugi sistemi (Seljak 2000, 34). Priznanje in sprejetje obstoja etičnih vzrokov revščine in umiranja pomeni prepoznavanje etične problematičnosti konceptov na katerih temelji tržni sistem, torej na problematičnosti primarnega kriterija-povečevanja dobička. Vendar v sedanjem civilizacijskem trenutku ni na obzorju družbene alternative kapitalizmu. Z vidika sonaravne zasnove gospodarstva pa je nujna takojšnja internalizacija stroškov okolja $\mathrm{v}$ proizvode in storitve.

$\mathrm{Z}$ vidika trajnostno sonaravne, pravične družbe je pomembna znotrajgeneracijska in medgeneracijska pravičnost ter $\mathrm{v}$ obeh odnos do narave, do drugih bitij. Zgodovinski pregled kaže, da so se dohodkovne razlike med posamezniki znotraj generacije znotraj držav in med državami v vsej zgodovini povečevale. Tako je tudi za 20. stoletje bilo značilno povečevanje dohodkovnih razlik med ljudmi in hkrati povečevanje izčrpavanja okolja, narave. Pravična družba naj bi po Rawsu temeljila na dveh načelih (v: Seljak 2000, 53):

- na načelu maksimalne svobode in enakih svoboščinah vseh državljanov (omejene le s svobodo drugih), saj se brez svobode ne more uveljaviti nobena oblika enakosti; 
- na načelu socialne in ekonomske enakosti s pojmovanjem, da so ekonomske razlike dopustne, vendar ne smejo škodovati najmanj priviligiranim in ne smejo rušiti socialne enakosti, izražene v enakem dostopu do vseh položajev v družbi.

Po mnenju Seljaka $(2000$, 59) je glavni krivec, da se principi uravnoteženosti s solidarnostjo in celostni pristop k razvoju ne uveljavita, ti. »etika« svobodnega tržišča. Za njim stoji namreč ideja, da ima tržna ekonomija svojo lastno moralo. Celo številni okoljski ekonomisti, ki zagovarjajo uporabo tržnih pobud kot sredstva kontrole onesnaževanja, poveličujejo trg kot rešitev problemov revščine in onesnaženja okolja. $V$ razvitih državah je potrebno uveljaviti etiko zviševanja kvalitete življenja znotraj ohranjanja ravni ali zmanjševanja trošenja naravnih virov. Dejstvo je, da vsaka rast, celo rast storitev, pomeni več proizvodnje, več porabe surovin in energije, s povratnimi učinki na okolje. Etična univerzalnost človeškega preživetja zahteva tako znotrajgeneracijsko kot medgeneracijsko enakost. Vendar univerzalnost ne pomeni enakih dohodkov ali bogastva, pomeni enake možnosti za vse prebivalke in prebivalce, uravnotežene $\mathrm{z}$ nosilnostjo okolja in zagotavljanjem preživetja, dostojne kakovosti življenja za vse.

Koncept in udejanjanje trajnostnosti/sonaravnosti je z Agendo 21 (1992) postal tudi praktični, a nepopolni vodnik svetovne okoljske politike, okolju prijaznejšega upravljanja in gospodarjenja. Kot planetarno razvojno vodilo je postalo razvojni imperativ EZ. Države, ki se opredeljujejo za trajnostni sonaravni razvoj sprejemajo njegova načela kot temeljni višji izbirni kriterij za vrednotenje nacionalne razvojne politike in mednarodnega sodelovanja (Radej, 2001b). Postopoma se izpopolnjujejo tudi nizi kazalcev (ekonomski, socialni in okoljski kazalci), ki naj bi čim bolj realno merili napredek planeta, držav, regij, mest v smeri trajnostnosti in sonaravnosti. Več dobička, delovnih mest in dobrin ni več sprejemljivo, če je doseženo na račun slabših življenjskih razmer naših vnukov (Munro 1995).

\section{GEOGRAFIJA, VARSTVO GEOGRAFSKEGA OKOLJA IN KONCEPT TRAJNOSTNOSTI/SONARAVNOSTI}

Sodobno pojmovanje človekovega napredka, človekove blaginje vključuje povečanje ekonomske, socialne in okoljske blaginje. Geografsko okolje predstavlja prostorsko areno in okoljski kapital človekove blaginje (Plut 2003). Za povečevanje okoljske sestavine človekove blaginje ne zadošča zgolj pasivno zasnovano varstvo geografskega okolja, temveč tudi »razvoj« geografskega okolja oziroma trajna raba naravnega (okoljskega) kapitala. Z uporabo besede trajnostnost želimo v geografiji kot poznavalci razmerja okolje-družba torej podčrtati cilj, težnjo trajnega oziroma trajnostnega ohranjanja naravnega (okoljskega) kapitala in hkrati dolgoročno (trajno) zasnovanega delovanja gospodarstva in celotne družbe. $\mathrm{V}$ tem pomenu je primerna samostojna uporaba besede trajnostnost. Prav tako je uporaba pojma trajnostnost primerna, če želimo poudariti širšo skrb za dvig kakovosti življenja, enakost ljudi v sedanjosti in prihodnosti, seveda v okviru zmogljivosti okolja, narave (Plut 2002a,b). Pojem trajnostnost je dejansko širši in večpomenski (ekonomski, družbeni-socialni in okoljski pomen) kot pojem sonaravnost, ki se veže na udejanjanje načel varstva okolja 
in narave, torej na okoljsko trajnostnost. Z besedo sonaravnost torej tudi v geografiji podčrtujemo način (usmeritev, smernica) za ohranjanje naravnega kapitala, torej naravi in (geografskemu) okolju trajno (primerneje dolgoročno) prilagojeno delovanje (dejavnosti) družbe (Plut 2002a). Načelo trajnostnosti se obravnava a) enoplastno (z vidika okolja in narave) ali b) večplastno ( $\mathrm{z}$ vidika okolja in narave, gospodarstva in družbe oziroma sociale). V obeh primerih pa je ključno izhodišče prilagajanje človeštva zmogljivostim (omejitvam) okolja in narave. Geografa Marsh in Grossa $(2002,14)$ sodita, da je potrebno celotni planet obravnavati kot geografsko integriran sistem, pokrajinska raba ne sme onemogočiti njegovo trajno delovanje. Geografi Skinner in drugi (1999, s. 269) izpostavljajo temeljno vlogo okolja kot premoženja, zalogo razpoložljivega blagostanja, katerega je potrebno uporabljati sočasno z investiranjem v raziskovanje in odkrivanjem novih virov za prihodnost. Geograf Clark $(1998,402)$ pa izrecno definira »sustainable development« kot »razvoj, kjer stopnja rabe virov ne presega stopnje obnavljanja oziroma ne degradira zalog virov«.

Različnost pojmovanja trajnostnosti povzroča tudi v geografiji vsebinske in terminološke težave. Predlagamo, da se pri geografskemu konceptu trajnostnosti/sonaravnosti trajnostnost opredeljuje kot načelo in sonaravnost kot način udejanjanja trajnostnosti $\mathrm{v}$ geografskem okolju, pokrajini. Udejanjanje načela trajnostnosti omogoča trajnostni sonaravni napredek, katerega ustanove in raziskovalci različno definirajo. Usmerjen je v okoljsko, ekonomsko in socialno trajen napredek vseh prebivalcev v okviru (različnih) zmogljivosti (omejitev) okolja v širšem pomenu besede, ki razen varstva bivalnega okolja (okoljevarstveni vidik v ožjem pomenu besede) vključuje še varstvo naravnih virov (širše virov okolja) in varstvo narave.

Geografija je prostorska veda, ki v ospredje postavlja preučevanje sestave in dinamike pokrajine ter razmerja med človekom in naravo (okoljem), ne pa sicer prav tako pomembne socialne (socialna varnost) in ekonomske (dvig materialnega blagostanja) razsežnosti trajnostnosti. Zato je primerno, da geografsko proučevanje poudari pomen pokrajinskim (regionalnim), okoljskim, naravnim značilnostim in procesom čim bolj prilagojenega, torej sonaravnega razvoja poselitve, gospodarstva, infrastrukture in pokrajinske rabe. S pojmom sonaravni razvoj (napredek) v geografiji poudarimo nujnost prostorske organizacije bivanja, dela in preživljanja prostega časa znotraj omejitev (zmogljivosti) narave, pokrajine (Plut 2003). Izhajamo torej zgolj iz udejanjanja okoljske razsežnosti trajnostnosti, torej ne obravnavamo ekonomske in socialne (družbene) razsežnosti trajnostnosti, trajnostnega razvoja. Na splošno, torej ne zgolj za potrebe geografije in sorodnih ved, je uporaba pojma sonaravni razvoj oziroma sonaravni napredek glede na vsebino primerna za označevanje načina udejanjanja načela okoljske (naravovarstvene in okoljevarstvene) trajnostnosti. V geografiji sonaravni razvoj-napredek pomeni usmeritev prostorskega, gospodarskega in regionalnega razvoja v okviru (različnih) zmogljivosti (omejitev) geografskega okolja, pokrajine. Obsega razvoj poselitve, gospodarstva, infrastrukture in pokrajinske rabe hkrati z varstvom (bivalnega) okolja, varstvo naravnih virov, varstvo narave oziroma ohranjanje pokrajinske, ekosistemske, vrstne pestrosti. Torej označuje okoljevarstveno in naravovar-stveno sprejemljivo stopnjo in obseg antropogene preobrazbe geografskega okolja.

Osnovna definicija sonaravnega (okoljskega) razvoja oziroma napredka izhaja iz težnje k doseganju kakovostnega, zdravega okolja in ohranjanja naravnih virov (naravnega kapitala), ki omogoča dolgoročen obstoj človeštva in drugih vrst. Aplikativna definicija so- 
naravnega razvoja pa postavlja v ospredje težnjo k zmanjševanju antropogenih energetskosurovinskih tokov in drugih pritiskov na raven, ki ne presega regeneracijskih in nevtralizacijskih zmogljivosti okolja ter ohranja pokrajinsko in biotsko raznovrstnost. Za sistemsko geografsko raziskovanje in načrtovanje sonaravnega (okoljskega) razvoja je primerna uporaba celovitega, regionalnega modela, ki izhaja iz medsebojne soodvisnosti fizično- in družbenogeografskih vzrokov in posledic. Kot metodološka zasnova je zato primerna model ti. DPSIR presoj, ki obsegajo okoljsko in socio-ekonomsko mrežo izbrane okoljske problematike z naslednjimi vsebinskimi polji: gonilne sile (pritiskov na okolje)-pritiski-stanje-posledice-odzivi (Graf 14) (EEA 2003). Ti. integralni geografski model raziskovanja geografskega okolja (in njegovih) sestavin z vidika okoljske trajnostnosti in okoljskih problemskih območij pa izhaja iz preučevanja naslednje verige povezanih okoljskih polj (Graf 15) (Plut, 2002a): stanje geografskega okolja (in njegovih sestavin)-posledice sprememb geografskega okolja-pritiski na geografsko okolje-občutljivost geografskega okolja-gonilne sile pritiskov na geografsko okolje (viri obremenjevanja)-odzivi na degradacijo geografskega okolja. V razliko od DPSIR modela Evropske agencije za okolje izhaja geografski model iz stanja geografskega okolja, vključuje občutljivost geografskega okolja in njegovih sestavin, pri odzivih oziroma predlogih pa postavlja v ospredje okolju prilagojeno, sonaravno prostorsko razmeščanje poselitve, infrastrukture in pokrajinske rabe. Kljub dodatnim vsebinsko-metodološkim dimenzijam gre pri sistemsko zasnovanemu, integralnemu proučevanju antropogene pokrajinske preobrazbe še vedno za tradicionalno regionalnogeografsko vsebinsko in metodološko zasnovo, z nekaterimi dodatnimi, specifičnimi metodološkimi prijemi in problemsko-funkcijsko zasnovanimi vsebinskimi poudarki. Okoljevarstveni vidiki in kazalci se $\mathrm{v}$ okviru koncepta sonaravnega (regionalnega) razvoja torej nanašajo na eno od njegovih treh temeljnih razsežnosti-tj. okoljska razsežnost (Vintar 2003).

Graf 14. DPSIR model raziskovanja Evropske agencije za okolje

Figure 14. DPSIR research model of the European Environment Agency

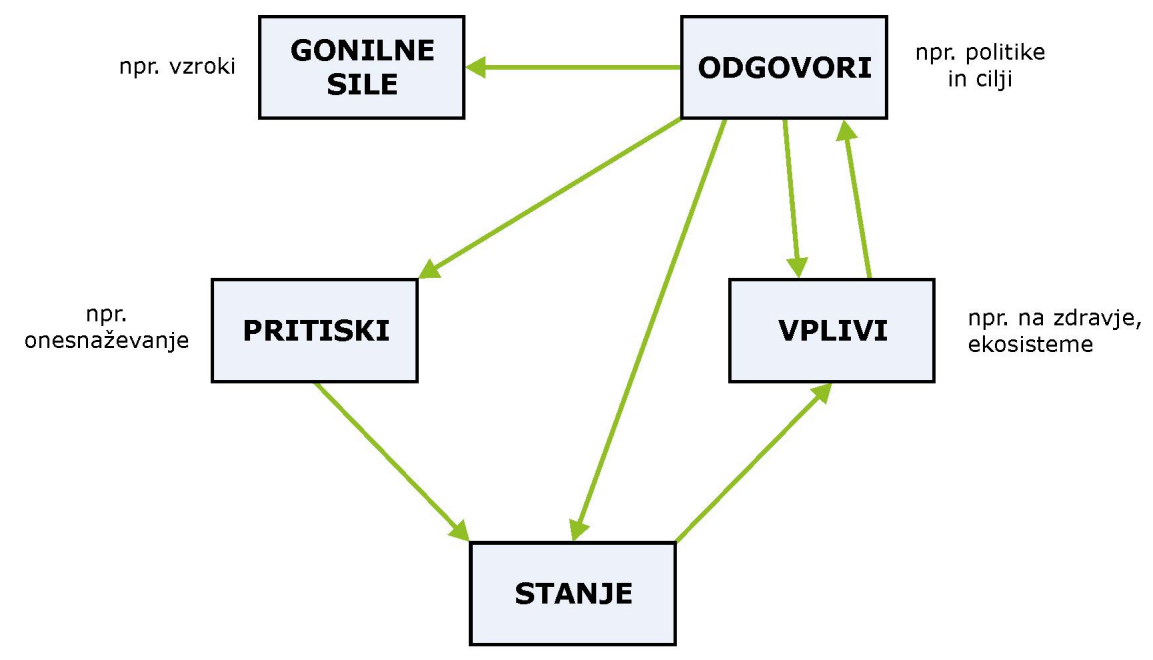

Oblikovanje: Andrej Herakovič 
Graf 15: zasnove integralnega modela raziskovanja geografskega okolja z vidika okoljske trajnostnosti

Figure 15: Concepts of integrated model of the research of geographic environment in the light of environmental sustainability
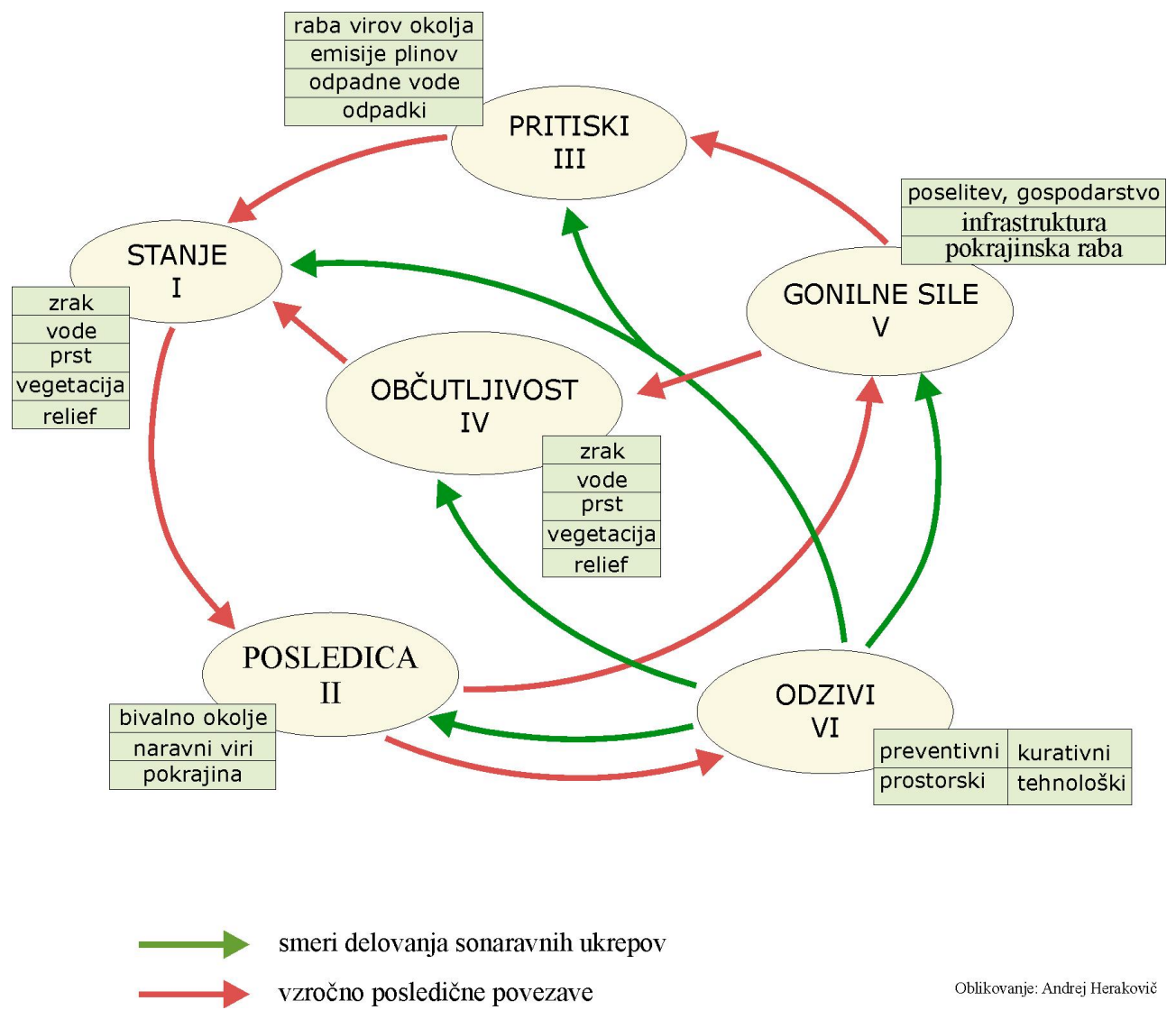

Oblikovanje: Andrej Heraković

V kolikor pa poudarimo tudi ekonomske in socialne značilnosti (regionalnega) razvoja, pa je umestno govoriti o trajnostno sonaravnem (regionalnem) razvoju (Plut, 2002a, b). V primeru, da npr. regionalni razvoj pojmujemo širše (razen načela okoljske in prostorske trajnostnosti), torej tudi z vidika načel gospodarske in socialne trajnostnosti (gospodarska in socialna sestavina blaginje), je torej primernejša uporaba pojma trajnostni (trajnostno) sonaravni regionalni razvoj (napredek).

Geografija poudarja pomen pokrajinskim potezam in procesom čim bolj prilagojenega-sonaravnega vzorca poselitve, gospodarstva, infrastrukture in pokrajinske rabe. V interdisciplinarno polje koncepta trajnostnosti/sonaravnosti vnaša geografija delno prezrto prostorsko in/ali pokrajinsko razsežnost. 
Nacionalni program varstva okolja (2004) je za okoljsko trajnostnost v temelju prevzel geografsko opredelitev trajnostnega razvoja kot »organizacijo gospodarstva, infrastrukture, poselitve in načina življenja v okviru nosilne sposobnosti okolja in naravnih vi$\operatorname{rov} \ll$.

\section{SKLEP}

Sprememba percepcije enosmerno zasnovanega gospodarskega razvoja sega v 70. leta 20 . stoletja. Naraščanje svetovne revščine, socialne in regionalne neenakosti je zamajalo prepričanje, da že sama splošna gospodarska rast zagotavlja reševanje vseh družbenih problemov. Hkrati so pritiski na okolje lokalno in regionalno presegli zmogljivosti okolja. Večplastno pojmovanje razvoja-napredka, torej koncept izboljšanja socialnega in materialnega blagostanja $\mathrm{v}$ razmerju do prebivalstva, naravnih virov in sprememb okolja, se je pojavilo $\mathrm{v}$ 80. letih 20. stoletja (Elliott 1994). Hkrati se je razvijal koncept trajnostno sonaravnega razvoja, ki povezuje zlasti koncept gospodarskega razvoja in varstva okolja. Trajnostnost/ sonaravnost je zasnovana na zahtevi zadovoljevanja potreb sedanje generacije brez degradacije okolja prihodnjih generacij (McKinney in Schoch 1998, 25). Vendar je osnovno pojmovanje razvoja $v$ današnjem svetu še vedno močno povezano zgolj z ekonomskim področjem, bruto domači proizvod pa je glavni cilj razvojnih politik (Seljak 2000, 2).

Problem koncepta trajnostnosti/sonaravnosti ni problem pomanjkanja znanja, temveč problem pomanjkanja politične volje za njegovo udejanjanje (Viederman 1995, 38). Vendar Goulet $(1995,44)$ dvomi, da sta pojma trajnostnost in razvoj združljiva. Opozarja, da še ni konkretnih primerov o obstoju okoljsko trajnostne ekonomije in industrije kjerkoli na svetu, v kolikor okoljsko trajnostnost pojmujemo kot ohranjanje zalog okoljskega kapitala. Udejanjanje koncepta trajnostnosti/sonaravnosti poziva $\mathrm{k}$ omejitvam potrošnje in rabe naravnih virov, razvoj pa se tradicionalno pojmuje kot trajna gospodarska rast, ki dejansko onemogoča udejanjanje koncepta trajnostnosti/sonaravnosti, saj povzroča izčrpavanje zalog neobnovljivih virov in onesnaževanje biosfere. Zaradi enačenja razvoja s trajno gospodarsko rastjo je umestno uporabljati pojem trajnostno sonaravni napredek, ki označuje splošen dvig kakovosti življenja, širše pojmovanega blagostanja.

Popolno udejanjanje načela trajnostnosti je torej zgolj ideja, podobno kot svoboda, enakost, spoštovanje človekovih pravic. Trajnostno sonaravno pot k idealnemu cilju označujejo zelo konkretni in realni konkretni cilji, ki izhajajo iz prehoda od zametkov k šibki (poudarke na kurativni okoljski politiki) in nato močni (preventivna okoljska politika) sonaravnosti na lokalnem, regionalnem, državnem in planetarnem nivoju. Regije in države so $\mathrm{v}$ različnem izhodiščnem položaju, zato bo prehod časovno dolgotrajen (obdobje dveh do treh generacij) in prostorsko zelo različen. Na začetku 21. stoletja so zgolj posamezne države (npr. Norveška, Švedska, Avstrija, Nova Zelandija) in regije gospodarsko razvitega sveta v fazi zelo šibkega trajnostno sonaravnega razvoja-napredka, ki izhaja iz ravnovesja gospodarskih, socialnih in okoljskih ciljev. Bogate države se morajo osredotočiti na zmanjšanje porabe naravnih virov na prebivalca, saj so stabilizacijo prebivalstva že dosegle. Zaradi omejenosti naravnih virov in zmogljivosti okolja za sprejemanje različnih odpadkov se bodo v gospodarsko razvitih državah antropogeni snovno-energetski tokovi morali zmanj- 
šati za 70-90 \% (Hille 1997; Bode 1998). Revne države pa se naj osredotočijo na kontrolo števila prebivalstva, saj se bo pičla poraba naravnih virov na prebivalca morala povečati (Daly 1991b, 35).

Osnovni namen trajnostno sonaravnega napredka je ustvarjanje okolja, ki bo ljudem omogočilo dolgo, zdravo in polnokrvno, kreativno življenje, ekonomski razvoj pa pripisuje največji pomen "vmesnemu cilju« in sicer pridobivanju dohodka, BDP. Le-ta pa je dejansko kazalec dejavnosti skupne proizvodnje in ne mera posameznikove blaginje. Namesto sredstva je BDP postal glavni cilj razvoja. Pomembno je namreč ne le kako se dohodek oziroma BDP poveča, temveč tudi kako se razdeli in na kakšen način je z vidika naravnega kapitala, virov okolja dosežen. Tudi za trajnostno sonaravni napredek je torej ekonomski razvoj pomemben, zlasti v obdobju svetovne revščine in pričakovano dolgem obdobju »okoljskega« prehoda.

Po mnenju strokovnjakov Svetovne banke za razvoj in okolje naj bi v obdobju naslednje generacije (do okoli leta 2030) morali doseči ključne cilje (šibkega) trajnostno sonaravnega razvoja (The World Bank 1992), v drugi polovici 21. stoletja pa naj bi družba že dosegla stopnjo močnega sonaravnega razvoja. Človeštvo in svetovno gospodarstvo naj bi torej preko krajšega obdobja šibke sonaravnosti stopilo v zahtevno obdobje močne sonaravnosti, zasnovane na ohranjanju obstoječih zalog naravnega kapitala (Bell in Morse, 2003). Danes prevladujoča predstava (vizija) o prihodnosti civilizacij pa (̌̌e) ne seže preko bogatenja in tehnološkega razvoja. Verjetno pa bo glavni izziv prihodnjega razvoja civilizacij celo bistveno širši od ekonomije, tehnološke moči in »environmentalizma«, saj bo segel na okoljsko, ekonomsko, socialno, politično in etično polje (Graf 16) (McKinney in Schoch, 1998). Kmetijski in industrijski civilizacijski preokretnici pospešene rasti pritiskov na okolje naj bi sledila tretja, trajnostno sonaravna, zasnovana na višji kakovosti življenja in hkrati bistveno zmanjšanju hitrosti izčrpavanja naravnih virov ter antropogenih pritiskov na okolje. McKinney in Schoch $(1998,9)$ sodita, da se je prehodno obdobje že začelo, vendar ne bi smelo trajati več kot 10-40 let.

V prvi polovici 21. stoletja se bodo snovno-energetski tokovi človeštva po večini tudi okoljsko radikalnejših scenarijev še povečevali. Strokovnjaki sodijo, da je z vidika materialne osnove človeštva druge polovice 21 . stoletja ključno polje v načrtovanem obdobju povečevanja materialnega blagostanja energetika, emisije $\mathrm{CO} 2$ pa temeljni kazalec (ne)uspešnosti energetskega prehoda. Po scenariju intenzivne, povečane rabe fosilnih goriv se naj bi globalne emisije $\mathrm{CO} 2$ do konca 21. stoletja še nekajkrat povečale na račun bistvenega povečanja emisij držav v razvoju in zmernega povečanja tudi v gospodarsko razvitih državah (Slika 17) (The World Bank 2003). Po podnebno prijaznem energetskem scenariju pa naj bi globalne emisije CO2 postopoma naraščale le do leta 2020, nato pa se naj bi po obdobju stabilizacije (2020-2050) v drugi polovici 21. stoletja začele zmanjševati in bile leta 2100 za polovico manjše kot leta 2000. Za uspešnost navedenega scenarija se bi morale takoj začeti spremembe, saj imajo npr. elektrarne, zgradbe življenjsko dobo 50 let in več. Večina tehnologij rabe obnovljivih virov energije potrebuje za raziskave 10-20 let, zato je potrebna takojšnja sonaravna energetska dejavnost in državne ter mednarodne podpore. Čeprav drža-ve v razvoju porabijo le $20 \%$ energije na prebivalca kot v državah razvoja, po-rabijo kar 3,8 krat več energije na 1 ameriški dolar BDP. Zato lahko države v razvoju in prehodu zelo 
Graf 16: Razvojne faze razmerja človek-okolje

Figure 16: Developments phases of the relationship man-environment

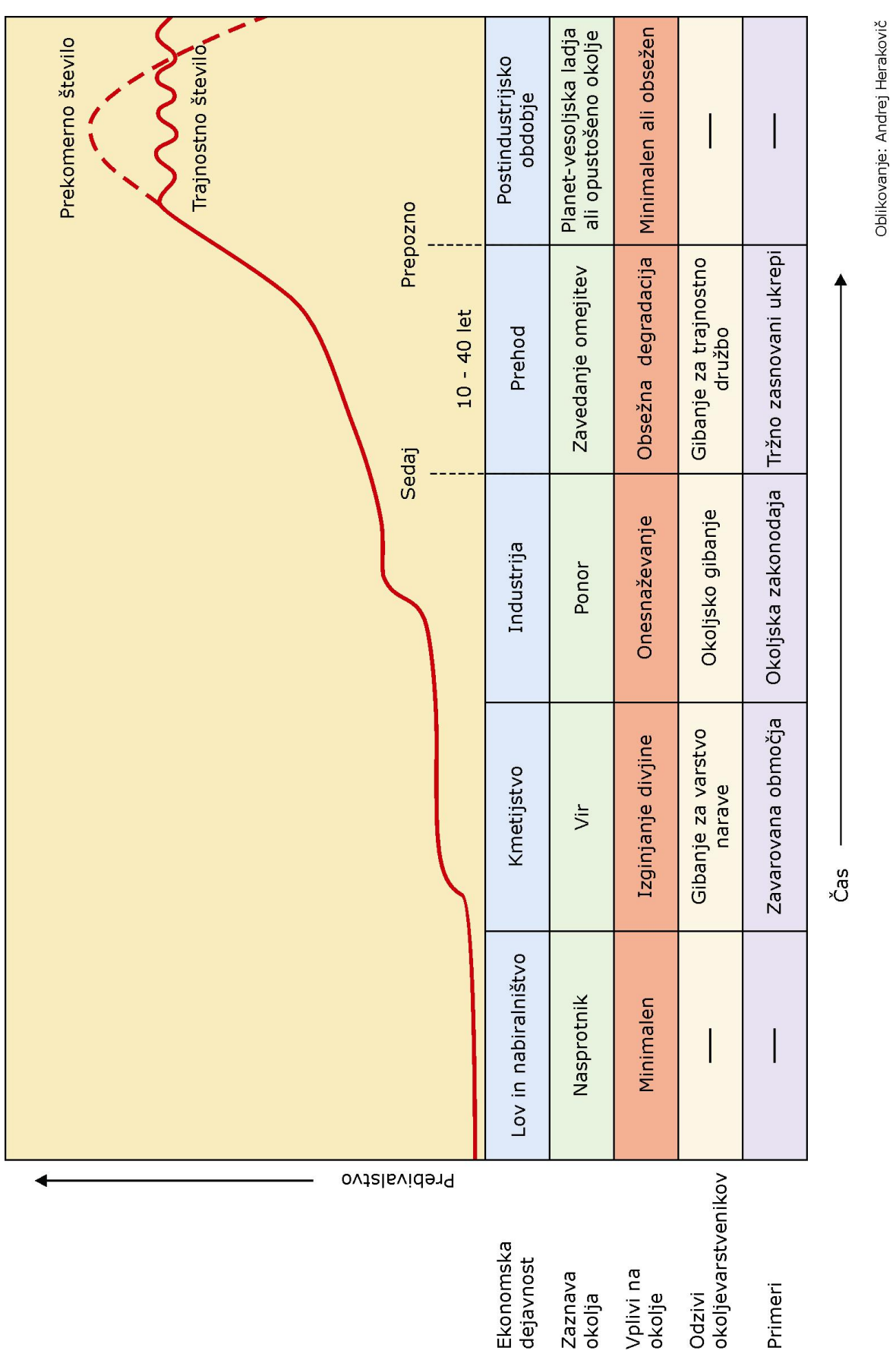


povečajo energetsko učinkovitost in zmanjšajo stroške za gorivo ter hkrati zmanjšajo emisije toplogrednih plinov (The World Bank 2003, 177).

Graf 17: Energetski scenariji za 21. stoletje

Figure 17: Energetic scenarios for the $21^{\text {st }}$ century

\section{Fosilna goriva - scenarij intenzivne porabe}

Emisije $\mathrm{CO}_{2}$ v GtC (ekvivalentno milijardam ton ogljika)
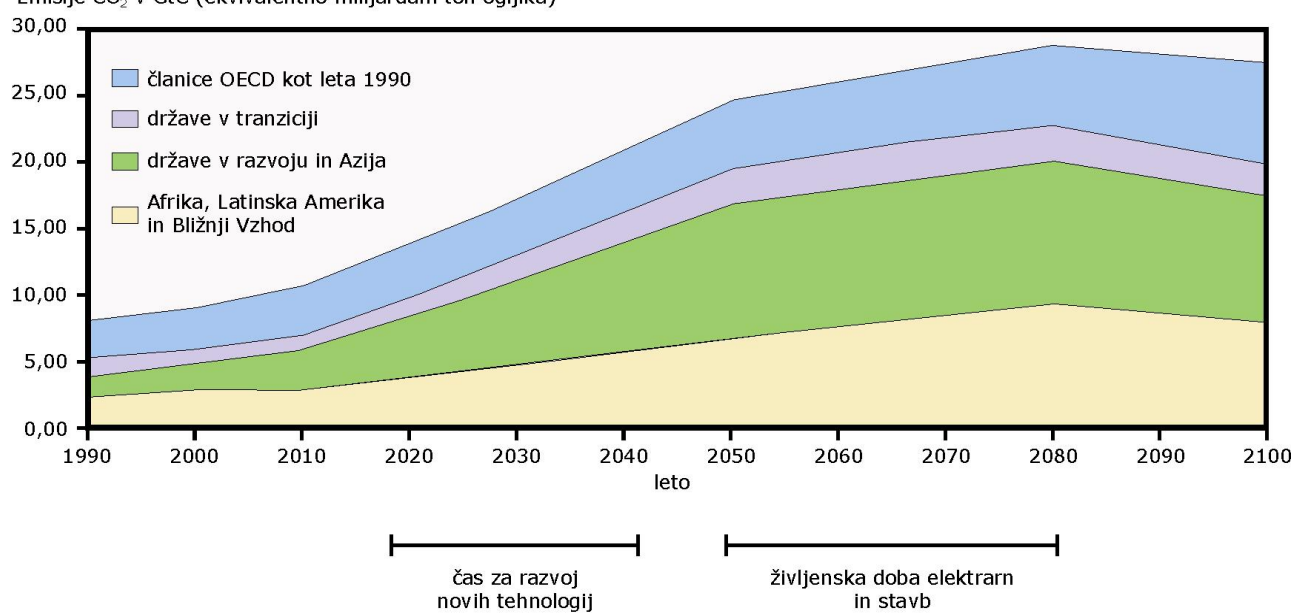

Podnebju prijazen energetski scenarij

Emisije $\mathrm{CO}_{2} \vee \mathrm{GtC}$ (ekvivalentno milijardam ton ogljika)

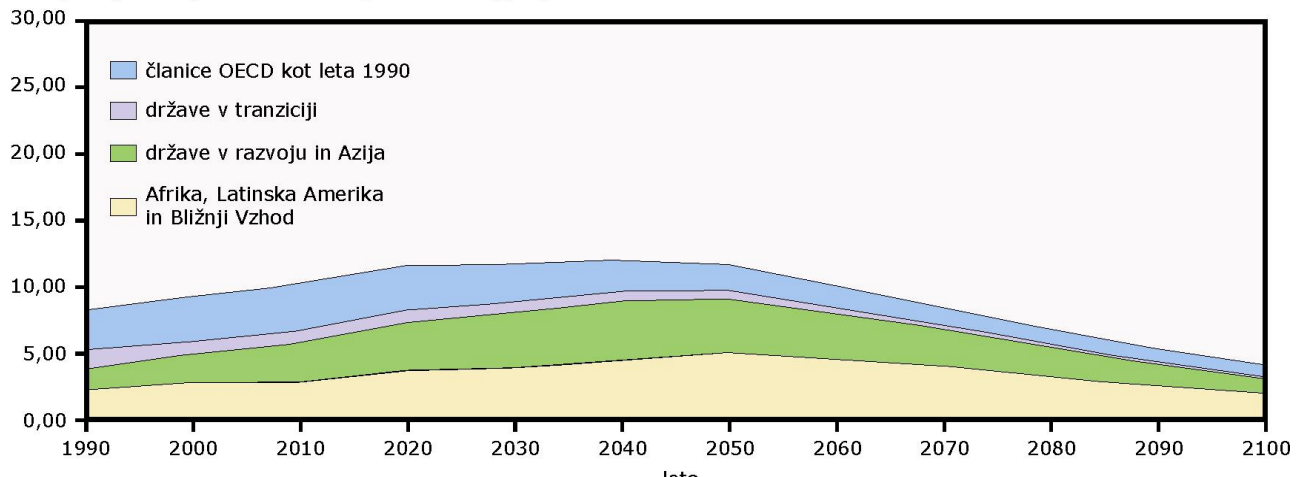

Temeljna dilema pa se glasi: ali bo človeštvo (družba) sprejelo ti. zunanje omejitve okolja in temu prilagodilo oziroma spremenilo sedanje obnašanje. Zato je okoljska razsežnost trajnost-nosti/sonaravnosti, torej trajno delovanje in prilagajanje socioekonomskih sistemov ozemeljsko širšim naravnim sistemom ključni cilj humanega napredka (Clayton in Radclift 1996). Uničujoči vplivi onesnaževanja okolja in socialne neenakosti niso neizogibni spremljevalci gospodarskega razvoja. 
Sodimo, da koncept trajnostnosti v paradigmo razvoja (bolje napredka) primarno vnaša okoljsko razsežnost - (omejene) možnosti razvoja glede na naravne vire (količina, kakovost), omejen prostor in absorpcijske zmogljivosti okolja, torej nujnost sonaravnosti materialnega življenja (Plut 2002a, c). Naslednja ključna novost pa je princip dolgoročnosti pri ocenjevanju tudi kratkoročno zastavljenih gospodarskih koristi. Za idejo trajnostnosti/sonaravnosti sta novosti vrednotenje in upoštevanje vplivov načina življenja sedanje generacije na prihodnje in s tem pogojeno iskanje vzorcev materialnega napredka znotraj omejitev okolja, vključno z njegovo planetarno dimenzijo. Iščejo se nove civilizacijske poti za izboljšanje, dvig kakovosti življenja brez povečanja porabe virov in ogrožanja delovanja in kakovosti planetarnega in pokrajinskih ekosistemov, biotske (ekosistemske, vrstne in genetske) raznovrstnosti. Na omejenem planetu ideja neskončne količinske rasti ni uresničljiva, možna pa je trajnostna, kakovostna rast, torej trajno izboljševanje kakovosti rabe naravnih virov. Gospodarski razvoj je trajnostno sonaraven le v primeru, da izboljšuje kakovost življenja brez povečevanja potrošnje virov (Constanza 1991). Težnja po takšnem izboljšan-ju kakovosti življenja, da bomo živeli in ustvarjali v okviru nosilnih zmogljivosti podpornih ekosistemov, naj bi predstavljala glavni cilj trajnostno sonaravnega prostorskega in regionalnega napredka. Stabilizacija svetovnega prebivalstva, nadomeščanje rabe fosilnih goriv z obnovljivimi in široka uporaba reciklaže so ključni koraki na poti k trajnostno sonaravnemu napredku (Brown in Mitchell 1998).

Ključne prihodnje globalne naloge na poti $\mathrm{k}$ trajnostno sonaravnem napredku v prvi polovici 21. stoletja so:

1. pospešen razvoj novih tehnologij rabe obnovljivih virov energije in reciklaže snovi (okolju prijazne tehnologije);

2. stabilizacija in zmanjševanje antropogenih snovno-energetskih tokov v gospodarsko razvitih državah;

3. stabilizacija svetovnega prebivalstva;

4. izboljšanje blagostnja tudi v državah razvoja v okviru nosilnosti okolja;

5. pravičnejša porazdelitev dohodkov med državami, regijami in prebivalci (socialna varnost).

Planetarnost vse večjega števila okoljskih problemov in izčrpavanje naravnih virov prinaša nov izziv interdisciplinarnemu raziskovanju stanja in vplivov sprememb kakovosti okolja ter načrtovanju prostorskega, regionalnega in gospodarskega razvoja držav, regij. Globalnost vplivov naraščajočih snovno energetskih tokov na okolje zahteva tudi oceno še »sprejemljivega« antropogenega izčrpavanja in obremenjevanja geografskega okolja določenega območja tako lokalno kot $\mathrm{z}$ vidika celotnega planetarnega ekosistema ter prihodnjih generacij. Ocenjevanje zmogljivosti okolja in naravnih virov za materialno dejavnost človeštva in nosilnosti okolja prilagojeno prostorsko razmeščanje prebivalstva in dejavnosti, usmerjanje (trajnostno) sonaravnega regionalnega napredka danes in $\mathrm{v}$ prihodnje predstavlja izjemen metodološki in vsebinski izziv naravoslovnih, družboslovnih, humanističnih, tehničnih in vseh drugih znanosti. Geografiji prinaša $\mathrm{v}$ teoriji in praksi priložnost, da tvorno in dejavno sodeluje pri prednostni civilizacijski nalogi udejanjanja sonaravnih vzorcev prostorske organizacije dejavnosti človeštva. 


\section{Viri in literatura}

Achterberg, W. 1999: From Sustainability to Basic Income. Planning Sustainability. London-New York.

Agenda 21: Programme of Action for Sustainable Development. United Nations Publications. New York, 1992.

Anko, B. 2000: Kako ohranjati (in ohraniti) najvrednejšo naravo? Naprej k naravi II (zbornik). Ljubljana.

Barbier, E., Burgess J., Folke C. 1995: Paradise Lost? London.

Bell, S., Morse S. 2003: Measuring Sustainability. London.

Bode, W. 1998: Trajnost? Ne narava, ampak človek »ve«, čeprav ne vedno najbolje. Naprej k naravi (zbornik). Ljubljana.

Brown, L., Mitchell, J. 1998: Oblikovanje novega gospodarstva. Zemlja 1998. Radovljica.

Carley, M., Christie, I. 1994: Managing Sustainable Development. London.

Clark, A. 1998: The Penguin Dictionary of Geography. London.

Clayton, A., Radclift, N. 1996: Sustainability - a Systems Approach. London.

Constanza, R. 1991: The Ecological Economics of Sustainabilitiy. Environmentally Sustainable Economic Development: Building on Brundtland. Paris.

Daly, H. 1991a: Sustainable Development: From Concept and Theory to Operational Principles. Resources, Environment and Population. Oxford.

Daly, H. 1991b: From Empty-World Economics to Full-World Economics. Environmentally Sustainable Economic Development: Building on Brundtland. Paris.

Dekleva, J. 1992: Prednostna vprašanja na področju urejanja prostora Slovenije v devetdesetih letih: v okviru načel uravnoteženo-trajnega razvoja in fleksibilnega načina produkcije. Koncept trajnega razvoja. Inštitut za geografijo. Ljubljana.

Elliott, J. 1994: An Introduction to Sustainable Development. London.

European Environment Agency: Environment in the European Union at the Turn of the Century. Copenhagen, 1999.

European Environment Agency: Europe's Environment: The Third Assessment. Copengagen. 2003.

Ferlin, F. 1997: Uspešnost novega sistema sonaravnega gospodarjenja z gozdovi v Sloveniji. Gozdarski vestnik 56/2. Ljubljana.

Ferry, L. 1998: Novi ekološki red. Ljubljana.

Georgescu Roegan, N. 1986: Bioekonomski vidiki entropije. Teorija in praksa 23/9-10. Ljubljana.

Georgescu Roegen, N. 1991: Entropijski zakon in ekonomski proces. Ekologija, ekonomija, entropija (zbornik). Maribor.

Gilpin, A. 1996: Dictionary of Environment and Sustainable Development. Chichester.

Goulet, D. 1995: Authetic Development: Is It Sustainable? A Sustainable World, IUCN, Sacramento-Claremont, s. 44- 59.

Grmič, V. 1994: Odgovornost za naravo. Človek in njegovo okolje. Ljubljana.

Gospodarska strategija Slovenije: Urad za makroekonomske analize in razvoj. Ljubljana, 2001. 
Haggett, P. 2001: Geography: A Global Synthesis. Harlow.

Haughton, G., Hunter, C. 1994: Sustainable Cities. London.

Hille, J. 1997: The Concept of Environmental Space. Copenhagen.

Hudson, R. 2000: Production, Places and Environment. Harlow.

Huntington, S. 1996: The Clash of Civilizations and the Remarking of World Order.

London.

Jacobs, M. 1999: Sustainability and Markets: On the Neo-classical Model of the Environment Economics. Planning Sustainability. London-New York.

Jones, G., Robertson, A., Forbes, J., Hollier, G. 1990: Collins Dictionary of Environmental Science. Glasgow.

Khosla, A. 1995: Foreword. A Sustainable World. Sacramento-Claremont.

Kirn, A. 1994: Od antropocentrične k ekocentrični etiki. Okolje v Sloveniji. Ljubljana.

Kirn, A. 2004: Narava - družba - ekološka zavest, Ljubljana.

Kovač, B. 1986: Politično ekonomski problemi ekologije in alternativni gospodarski razvoj. Teorija in praksa 23/9-10. Ljubljana.

Kovačič, A. 2001: Merjenje globalne konkurenčnosti držav ter pomen varstva okolja IB revija 2001/4. Ljubljana, s. 53-64

Kryštufek, B. 1999: Osnove varstvene biologije. Ljubljana.

Kupchella, C., Hyland, M. 1996: Environmental Science. London.

Lah, A. 1995: Okolje in človek (leksikon). Ljubljana.

Lah, A. 2002: Okoljski pojavi in pojmi. Ljubljana.

Leveque, C., Mounolou J. 2003: Biodiversity. Chichester.

Loucks, D., Gladwell, J. 1999: Sustainability Criteria for Water Resource Systems. Cambridge.

Macarol, B. 2001: Pravilna raba okoljske terminologije (zbornik). Moravske Toplice.

Marsh, W., Grossa, J. 2002: Environmental Geography. New York.

Marušič, I. 1996: Prispevek k splošni teoriji varstva. Varstvo narave zunaj zavarovanih območij (zbornik). Ljubljana.

McKinney, M., Schoch, R. 1998: Environmental Science. Sudbury.

Meadowcroft, J. 1999: Planning for Sustainable Development: What Can Be Learned from the Critics. Planning Sustainability. London-New York.

Meadows, D.H., Meadows D.L., Randers J. 1995: Beyond the Limits. London.

Munro, D. 1995: Sustainability: Rhetoric or Reality. A Sustainable World. SacramentoClaremont.

Mušič, V.B. 1992: Pogled na koncept uravnoteženega razvoja. Koncept trajnega razvoja. Inštitut za geografijo. Ljubljana.

Nacionalni program varstva okolja 2005-2008. Ministrstvo za okolje, prostor in energijo. Ljubljana, 2004.

Nebel, B., Wright, R. 1998: Environmental Science. New Yersey.

Odum, P. 1989: Ecology and Our Endangered Life - Support Systems. Sundarland.

Osterc, J. 1998: Prizadevanja za uvajanje sonaravnega kmetijstva v Sloveniji, Kmetijstvo in okolje (zbornik). Ljubljana.

Pearce, D. 1993: Economic Values and Natural World. London. 
Pearce, D. 1994: Measuring Sustainable Development. London.

Pirnat, J., Anko, B. 2001: Znanost o okolju (skripta). Biotehniška fakulteta. Ljubljana.

Plut, D. 1991: Entropijska zanka. Didakta. Radovljica.

Plut, D. 1998: Varstvo geografskega okolja (univ. učbenik). Oddelek za geografijo, Filozofska fakulteta. Ljubljana.

Plut, D. 2002a: Okoljevarstveni vidiki prostorskega razvoja Slovenije. Razprave Filozofske fakultete. Ljubljana.

Plut, D. 2002b: Teoretični in terminološki vidika koncepta trajnostnosti/sonaravnosti. Geografski vestnik 74/1, Ljubljana, s. 73-86.

Plut, D. 2002 c: Concepts of Global Assessment of Environmental Limits on Material Activity of the Humankind, Moravian Geographical Reports 10, 1/2002, Brno, s. 2-7.

Plut, D. 2003: Geografske metode proučevanja degradacije okolja. Ljubljana.

Poročilo o človekovem razvoju-Slovenija 1998.Urad za makroekonomske analize in razvoj. Ljubljana, 1998.

Prosen, A. 1993: Sonaravno urejanje podeželskega prostora. Ljubljana.

Pugh, C. 1996a: Introduction. Sustainability, the Environment and Urbanization. London.

Pugh, C. 1996b: Conclusions. Sustainability, the Environment and Urbanization. London.

Radej, B. 1992: Vrste ekonomskih inštrumentov varstva okolja in njihova uporaba. Ljubljana.

Radej, B., Povšnar, J., Kovač, M., Zakotnik, I., Gmeiner, P., Hanžek, M., Seljak, J. 2000: Shema indikatorjev monitoringa okoljskega razvoja. Delovni zvezki Urada za makroekonomske analize in razvoj št. 7/letnik IX. Ljubljana.

Radej, B. 2001a: Od konvencionalnega ekonomskega razvoja k trajnostnemu - implementacijske teze. IB revija 2001/4. Ljubljana, 7-11.

Radej, B. 2001b: Uvod v ekonomiko trajnostnega razvoja. IB revija 2001/4, Ljubljana, 1326.

Rees J. 1992: Natural Resources. London-New York.

Redclift, M. 1999: Pathways to Sustainability: Issues, Policies, and Theories. Planning Sustainability. London-New York.

Seljak, J. 2000: Merjenje uravnoteženega razvoja (doktorska disertacija). Ekonomska fakulteta. Ljubljana.

Senjur, M. 1993: Gospodarski razvoj in razvojna ekonomika. Radovljica.

Slovenski pravopis. Založba ZRC. Ljubljana, 2001.

Smith, G. 1993: Impact Assessment and Sustainable Resource Managment. New York.

Šolar, S.V. 2004: Trajnostno gospodarjenje z mineralnimi surovinami v Sloveniji, Geološki zavod Slovenije. Ljubljana.

Špes, M., Cigale, D., Lampič, B., Natek, K., Plut, D., Smrekar, A.A., Vovk, A. 1999: Ranljivost okolja kot omejitveni dejavnik prostorskega razvoja Slovenije. Inštitut za geografijo. Ljubljana.

Tarman, K. 1992: Osnove ekologije in ekologija živali. Ljubljana.

Therivel, R., Morris, P. 2001: Introduction. Methods of Environmental Impact Assessment. London - New York.

The World Bank. Development and the Environment. Oxford, 1992. 
Townroe, P. 1996: Urban Sustainability and Social Cohesion. Sustainability, the Environment and Urbanization. London.

Viederman, S. 1995: Knowledge for Sustainable Development: What Do We Need to Know. A Sustainable World. Sacramento-Claremont.

Vintar. K. 2003: Okoljevarstveni vidiki sonaravnega regionalnega razvoja (magistrsko delo). Oddelek za geografijo Filozofske fakultete. Ljubljana.

World Commission on Environment and Development. Our Common Future. Oxford-New York, 1987.

\section{THEORETICAL AND SUBSTANTIVE CONCEPT OF SUSTAINABLE CLOSE-TO-NATURE MANAGED PROGRESS}

\section{Summary}

A comprehensive definition of the welfare of a state, region, family or an individual involves economic, social and environmental welfare. The latter has been left to economic elemental forces, which is indicated by the overuse of natural resources and services of the environment and the related degradation of the components of geographic environment. An environmental scheme of a different paradigm and concept of the progress of the mankind thus represents a civilisational challenge, which may be compared only with another global challenge - seeking for planetary coexistence in the period of the clash of civilisations, in particular the so called western (currently the most influent) and other civilisations. Globality of economic, social and environmental problems requires a global response, made somehow like a net weaved of appropriate local answers.

Opinions of ecologists and economists differ significantly when discussing the possibilities and ways of attaining economic and environmental sustainability by means of market mechanisms. Environmental problems are not a result of market mechanism as such but of the mode of its use, since the market may not set its own limits (limitations). The role of the market in the irreversible impairment of the environment has probably been overestimated since also the socialistic non-market system, which is disappearing, is characterised by degradation of the environment, as well as by global economic non-competibility. Legislative and economic instruments may encourage producers and consumers to decrease the burdening of the environment, recycling, use of renewable energetic resources. Total costs for the eradication of consequences of environment pollution and for the use of primary raw materials and fossil fuels should be, in a corresponding period, higher than costs incurred by the introduction of technologies which are more appropriate in the light of environmental protection and by the use of renewable resources of energy.

A significant difference exists between definitions applied by economists and those applied by ecologists in relation to the concept of the possible economic growth as well as to the concept of the meaning of natural capital in the total capital for future generations. The differences result from different viewpoints and presumptions regarding the future meaning of the components of social capital (natural, physical and generated), considering 
the inter-generational responsibility or justice. Looking in the light of future generations, ecologists point out that particular attention should be paid to the protection of natural resources. However according to the presumption of economists the whole composition of social capital should be taken into account, which comprises natural resources (environment), knowledge, generated capital, etc. When trying to approach to the ecological viewpoint, some economists include natural capital into economic calculations, however not all functions of the ecosystem can be subject to monetary evaluation. Economic effectiveness is based on profit, and the latter on growth. Quantitative increase of economy (however not the quality) as a sub-system of the planetary ecosystem is not compatible with universal limitations (space, natural resources, self-cleaning capacities of the environment). It is a matter of conflict between the economic concept of the maximality of profit and the ecological concept of optimality. According to the thesis, still defended by some economists, the global environment is characterised by high carrying capacity, and pollution flows should have not yet reached the critical level.

The sustainable close-to-nature managed society shall thus have to consider inclusion into globalisation procedures, aiming at their environmental, regional and social balance.

A sustainable society (greater circularity of productional and consumer processes in place of the present mostly linear) shall be conditioned by the following:

- materials of the core of the Earth should not be increasing systematically (permanently) in the ecosphere;

- materials, produced by the society in the ecosphere, should not be increasing systematically;

- $\quad$ physical basis of productivity and diversity of nature should not be subject to systematical exploitation;

- equitable and efficient use of natural resources should take into account satisfaction of human needs.

A close-to-nature managed society thus indicates a society putting into practice sustainability in the environmental field. A sustainable (sustainable-close-to-nature managed) society shall therefore mean a society of a human-worthy material welfare and quality of life and social security in the healthy environment, free of any threat posed to the conditions for survival and to development of future generations and biosphere.

Looking from the point of view of implementing the concept of sustainability, the sustainable close-to-nature managed society is characterised by: a) continuation from one generation to another, b) in the absence of exploitation of the basis of sources through exceeding the sustainable yield, or the production of pollution above the natural capacity of their absorption. It indicates a society, the operating of which is oriented into non-exploiting the resources of raw materials and energy, on which it depends. The sustainable close-to-nature managed society is a society, which had learned to live within the limitations of the environment, environmental sustainability therefore being essential, in particular a scheme of material functioning of the society on the basis of the principle of a) precaution and b) reversibility (with no irreversible environmental changes). It is based on the use of renewable natural resources, stable level of population and material flows and the pres- 
ervation of life-supporting systems. Its economic and technological basis is represented by the sustainable close-to-nature managed economy and sustainable close-to-nature managed technology. The sustainable close-to-nature managed economy enables welfare and employment of numerous generations in the absence of environment degradation. However the sustainable close-to-nature managed technology enables the mankind to satisfy the needs with minimum environmental impacts.

A sustainable close-to-nature managed society is supposed to be characterised by environmentally within- and inter-generational responsibility, social safety and justice, economic efficiency, non-violence towards human beings (world peace) and other species, it should furtheron ensure the enhancement of the quality of life, human progress within the limitations of the environment (ecosystems). A one-sided attainment of a certain objective, for example increase of the income on the account of the increased burdening of the environment and exploitation of natural resources, of enhanced social and regional disparities and of the gulf between the wealthy North and poor South, are not characteristics of a sustainable close-to-nature managed society. A society is also not considered as sustainable close-to-nature managed, if it is characterised by preserved environment and at the same time by poverty of its inhabitants. A key objective in the social field is the increased quality of life for each individual. Something must be wrong with basic ethical values, which represent the basis for economic and all other systems, on a planet, where some individuals earn more than a million of inhabitants of poor countries and where people die of hunger. To recognise and accept the existence of ethical causes of poverty and dying means to recognise ethical problematic of concepts which form the basis for market system, which is thus the problematic of the primary criterion - profit increase. However no social alternative to capitalism is anticipated in the present cultural moment. Looking from the viewpoint of the close-to-nature managed concept of economy, immediate internalisation of environmental costs into products and services is essential.

In the opinion of some environmental economists, the principles of balance with solidarity and integrated approach to development can not be established due to the so-called "ethics " of the free market. The idea of the free market is that market economy has its own morals. Market as a solution to the problems associated with poverty and environmental pollution is praised even by numerous environmental economists who speak in favour of the use of market initiatives as a means of controlling the pollution. In developed countries there is a need to implement the ethic of increased quality of life within the maintained level or decreased wasting of natural sources. Any growth, even of services, means increase in production, in consumed raw materials and energy, with reversible effects on the environment. Ethical universality of a human being's survival requires intra-generational as well as inter-generational equity. However universality does not mean the same incomes or wealthiness, but the same opportunities for all inhabitants, balanced with the bearing capacity of the environment and ensuring the survival, decent quality of life for everybody.

According to the opinion of the experts of the World Bank for development and environment, key objectives of the (weak) sustainable close-to-nature managed development should be attained within the period of the next generation (until about 2030), and in the second half of the $21^{\text {st }}$ century the society should reach the level of strong close-to-nature 
managed development. The human kind and the world economy should thus trespass a shorter period of weak close-to-nature management to reach a demanding period of strong close-to-nature management, based on the perseverance of the existing stocks of natural capital. However nowaday's vision of the future of generations does (still) not reach further than getting rich and technologically developed. The main challenge of the future development of civilisations shall probably be substantially broader than economy, technological power and »environmentalism«, since it is to extend on environmental, economic, social, political and ethical field. Agricultural and industrial civilisational turning point of quickened pressures on the environment is to be followed by the third, sustainable close-tonature managed one, which is to be based on the higher quality of life and at the same time decreased anthropogenic pressures on the environment.

The main dilemma is the following: will the mankind (society) accept the so-called external limitations of the environment and accordingly adjust or change the present behaviour. Therefore the key objective of human progress is the environmental dimension of sustainability/close-to-nature management, thus permanent activity and adjustment of socioeconomic systems to the natural ecosystems of bigger territorial dimensions. Economic development is not necessarily followed by detrimental effects of environmental pollution and social inequality.

We are of the opinion that the concept of sustainability primarily introduces environmental dimension into the paradigm of development - (limited) development possibilities with regard to natural sources (quantity, quality), limited space and absorptive capacities of the environment, which is consequently the necessity of the close-to-nature management of material life. The next key novelty refers to the principle of long-termity also at assessing economic benefits on a short-term basis. Features which are new to the idea on sustainability/close-to-nature management are the evaluation and taking into account the impacts of the present generation's way of life on future generations and the consequent searching for patterns of material progress within the limitations of the environment, including its planetary dimension. New civilisational paths are looked for, aiming at improving, raising the quality of life in the absence of the increased use of sources and jeopardising the functioning and quality of planetary and spatial ecosystems, biological (ecosystem, species and genetic) diversity. Limitations of the planet do not allow for an unlimited quantity growth, however a sustainable, quality growth is possible, meaning permanent improvement of the quality of exploitation of natural resources. Economic growth may be sustainable close-tonature managed only if improving the quality of life without increasing the exploitation of sources. The prime objective of the sustainable close-to-nature managed spatial and regional development, in better words progress, is a tendency to such improvement in quality of life, thus to live and create within the framework of the bearing capacities of supporting systems. Stabilisation of world population, replacing the use of fossil fuels with renewable ones and wider use of recycling are the key elements towards the sustainable close-tonature managed progress. 